Cochrane Database of Systematic Reviews

\title{
Antibiotic treatment for the sexual partners of women with bacterial vaginosis (Review)
}

Amaya-Guio J, Viveros-Carreño DA, Sierra-Barrios EM, Martinez-Velasquez MY, Grillo-Ardila CF

Amaya-Guio J, Viveros-Carreño DA, Sierra-Barrios EM, Martinez-Velasquez MY, Grillo-Ardila CF.

Antibiotic treatment for the sexual partners of women with bacterial vaginosis.

Cochrane Database of Systematic Reviews 2016, Issue 10. Art. No.: CD011701.

DOI: 10.1002/14651858.CD011701.pub2.

www.cochranelibrary.com 
TABLE OF CONTENTS

ABSTRACT

PLAIN LANGUAGE SUMMARY

SUMMARY OF FINDINGS

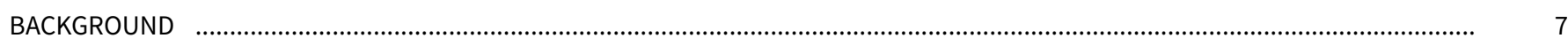

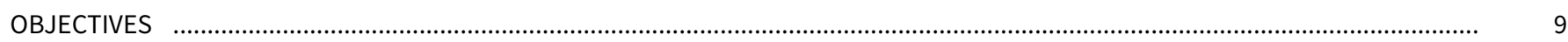

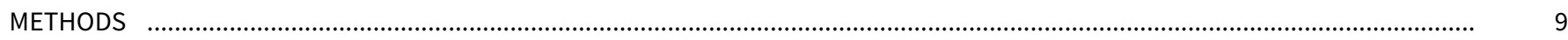

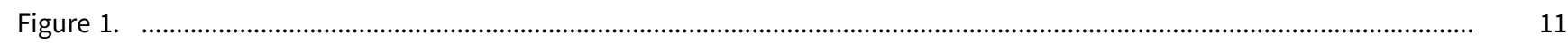

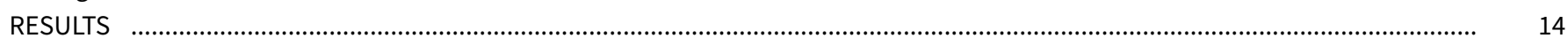

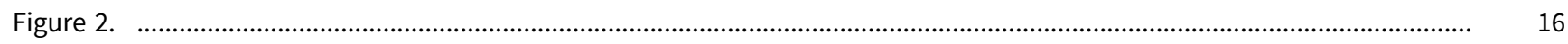

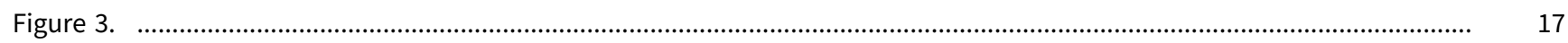

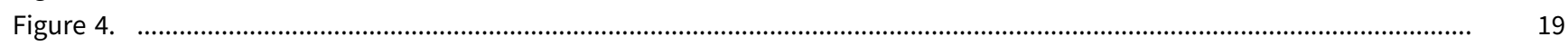

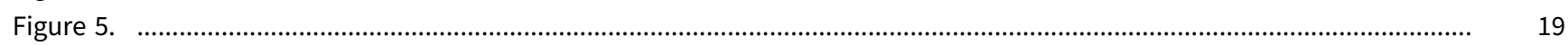

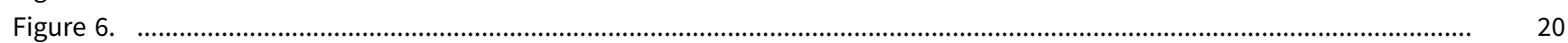

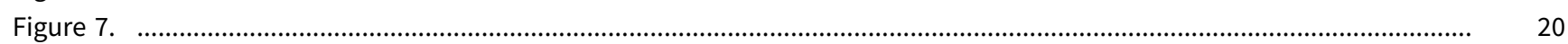

Figure 8.

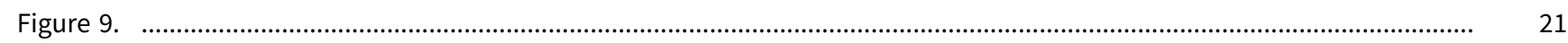

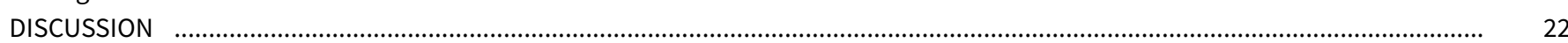

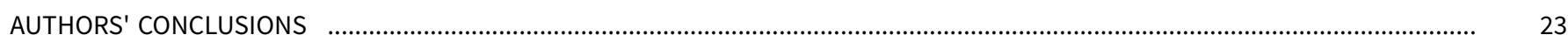

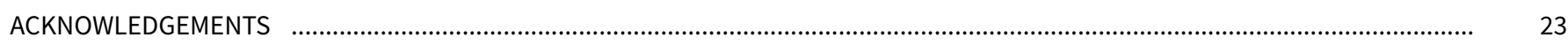

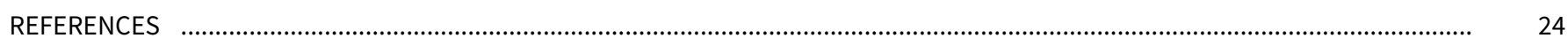

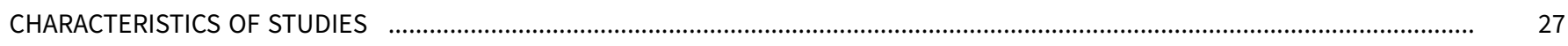

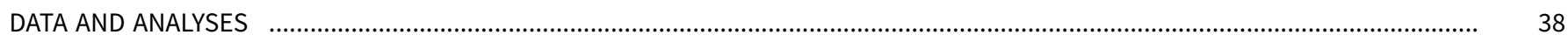

Analysis 1.1. Comparison 1 Any antibiotic treatment versus placebo, Outcome 1 Recurrence of BV between the first and fourth 39 week.

Analysis 1.2. Comparison 1 Any antibiotic treatment versus placebo, Outcome 2 Recurrence of BV after the fourth week. ....... 39

Analysis 1.3. Comparison 1 Any antibiotic treatment versus placebo, Outcome 3 Clinical improvement during the first week. .. 39

Analysis 1.4. Comparison 1 Any antibiotic treatment versus placebo, Outcome 4 Clinical improvement between the first and 40 fourth week.

Analysis 1.5. Comparison 1 Any antibiotic treatment versus placebo, Outcome 5 Clinical improvement after the fourth week. .. Analysis 1.6. Comparison 1 Any antibiotic treatment versus placebo, Outcome 6 Symptomatic improvement during the first week.

Analysis 1.7. Comparison 1 Any antibiotic treatment versus placebo, Outcome 7 Symptomatic improvement between the first and fourth week.

Analysis 1.8. Comparison 1 Any antibiotic treatment versus placebo, Outcome 8 Symptomatic improvement after the fourth week.

Analysis 1.9. Comparison 1 Any antibiotic treatment versus placebo, Outcome 9 Minor adverse events during therapy in sexual partner.

Analysis 2.1. Comparison 2 Any antibiotic treatment versus no intervention, Outcome 1 Recurrence of BV after the fourth week.

Analysis 2.2. Comparison 2 Any antibiotic treatment versus no intervention, Outcome 2 Clinical improvement between the first and fourth week.

Analysis 2.3. Comparison 2 Any antibiotic treatment versus no intervention, Outcome 3 Symptomatic improvement after the fourth week.

Analysis 3.1. Comparison 3 Any antibiotic treatment versus placebo (by antibiotic type), Outcome 1 Recurrence of BV after the fourth week.

Analysis 3.2. Comparison 3 Any antibiotic treatment versus placebo (by antibiotic type), Outcome 2 Clinical improvement during the first week.

Analysis 3.3. Comparison 3 Any antibiotic treatment versus placebo (by antibiotic type), Outcome 3 Clinical improvement between the first and fourth week.

Analysis 3.4. Comparison 3 Any antibiotic treatment versus placebo (by antibiotic type), Outcome 4 Clinical improvement after the fourth week.

Analysis 3.5. Comparison 3 Any antibiotic treatment versus placebo (by antibiotic type), Outcome 5 Minor adverse events during therapy in sexual partner. 
Analysis 4.1. Comparison 4 Any antibiotic treatment versus placebo (by dose), Outcome 1 Clinical improvement during the first week.

Analysis 4.2. Comparison 4 Any antibiotic treatment versus placebo (by dose), Outcome 2 Clinical improvement between the first and fourth week.

Analysis 4.3. Comparison 4 Any antibiotic treatment versus placebo (by dose), Outcome 3 Clinical improvement after the fourth week.

Analysis 4.4. Comparison 4 Any antibiotic treatment versus placebo (by dose), Outcome 4 Symptomatic improvement during the first week.

Analysis 4.5. Comparison 4 Any antibiotic treatment versus placebo (by dose), Outcome 5 Symptomatic improvement between the first and fourth week.

Analysis 4.6. Comparison 4 Any antibiotic treatment versus placebo (by dose), Outcome 6 Minor adverse events during therapy in sexual partner.

Analysis 5.1. Comparison 5 Any antibiotic treatment versus placebo (attrition bias), Outcome 1 Recurrence of BV after the fourth week.

Analysis 5.2. Comparison 5 Any antibiotic treatment versus placebo (attrition bias), Outcome 2 Clinical improvement during the first week.

Analysis 5.3. Comparison 5 Any antibiotic treatment versus placebo (attrition bias), Outcome 3 Clinical improvement between the first and fourth week.

Analysis 5.4. Comparison 5 Any antibiotic treatment versus placebo (attrition bias), Outcome 4 Clinical improvement after the fourth week.

Analysis 5.5. Comparison 5 Any antibiotic treatment versus placebo (attrition bias), Outcome 5 Symptomatic improvement during the first week.

Analysis 5.6. Comparison 5 Any antibiotic treatment versus placebo (attrition bias), Outcome 6 Symptomatic improvement between the first and fourth week.

Analysis 5.7. Comparison 5 Any antibiotic treatment versus placebo (attrition bias), Outcome 7 Symptomatic improvement after the fourth week.

Analysis 5.8. Comparison 5 Any antibiotic treatment versus placebo (attrition bias), Outcome 8 Minor adverse events during therapy in sexual partner.

APPENDICES

CONTRIBUTIONS OF AUTHORS

DECLARATIONS OF INTEREST

SOURCES OF SUPPORT

INDEX TERMS 
[Intervention Review]

\section{Antibiotic treatment for the sexual partners of women with bacterial vaginosis}

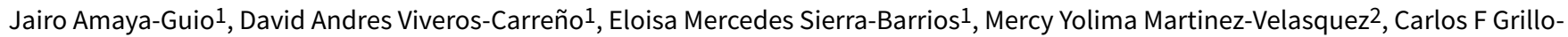
Ardila1,3

1Department of Obstetrics and Gynecology, Faculty of Medicine, Universidad Nacional de Colombia, Bogota, Colombia. ${ }^{2}$ Department of Obstetrics and Gynecology, Clinica Universitaria Colombia, Sanitas, Bogota, Colombia. ${ }^{3}$ Clinical Research Institute, Faculty of Medicine, Universidad Nacional de Colombia, Bogota, Colombia

Contact: Jairo Amaya-Guio, Department of Obstetrics and Gynecology, Faculty of Medicine, Universidad Nacional de Colombia, Bogota, Colombia.jamayaguio@gmail.com, jaamayagu@unal.edu.co.

Editorial group: Cochrane STI Group.

Publication status and date: New, published in Issue 10, 2016.

Citation: Amaya-Guio J, Viveros-Carreño DA, Sierra-Barrios EM, Martinez-Velasquez MY, Grillo-Ardila CF. Antibiotic treatment for the sexual partners of women with bacterial vaginosis. Cochrane Database of Systematic Reviews 2016, Issue 10. Art. No.: CD011701. DOI: 10.1002/14651858.CD011701.pub2.

Copyright (c) 2016 The Cochrane Collaboration. Published by John Wiley \& Sons, Ltd.

\section{A B S T R A C T}

\section{Background}

Bacterial vaginosis (BV) is an infection that has a prevalence between $10 \%$ to $50 \%$ worlwide. BV results in an imbalance of the normal vaginal flora. Microorganisms associated with BV have been isolated from the normal flora of the male genital tract, and their presence could be related to the recurrence of BV after antibiotic treatment. Therefore, the treatment of sexual partners could decrease the recurrence of infection and possibly the burden of the disease.

\section{Objectives}

To assess the effectiveness in women and the safety in men of concurrent antibiotic treatment for the sexual partners of women treated for BV.

\section{Search methods}

We searched the Cochrane Sexually Transmitted Infections Group Specialized Register (23 July 2016), CENTRAL (1991 to 23 July 2016 ), MEDLINE (1946 to 23 July 2016), Embase (1974 to 23 July 2016), LILACS (1982 to 23 July 2016), the World Health Organization (WHO) International Clinical Trials Registry Platform (ICTRP) (23 July 2016), ClinicalTrials.gov (23 July 2016) and the Web of Science ${ }^{\text {TM }}$ (2001 to 23 July 2016). We also handsearched conference proceedings, contacted trial authors and reviewed the reference lists of retrieved studies.

\section{Selection criteria}

Randomized controlled trials (RCTs) that compared the concurrent use of any antibiotic treatment with placebo, no intervention or any other intervention by the sexual partners of women treated for BV.

\section{Data collection and analysis}

Three review authors independently assessed trials for inclusion, extracted data and assessed the risk of bias in the included studies. We resolved any disagreements through consensus. We assessed the quality of the evidence using the GRADE approach.

\section{Main results}

Seven RCTs (1026 participants) met our inclusion criteria, and pharmaceutical industry funded four of these trials. Five trials (854 patients) compared any antibiotic treatment of sexual partners with placebo. Based on high quality evidence, antibiotic treatment does not increase 
the rate of clinical or symptomatic improvement in women during the first week (risk ratio (RR) $0.99,95 \%$ confidence interval (CI) 0.96 to 1.03; 712 participants, four studies; RR $1.06,95 \% \mathrm{Cl} 1.00$ to $1.12 ; 577$ patients, three studies, respectively), between the first and fourth week (RR 1.02, 95\% Cl 0.94 to 1.11; 590 participants, three studies; RR 0.93, 95\% Cl 0.84 to 1.03; 444 participants, two studies; respectively) or after the fourth week (RR $0.98,95 \% \mathrm{Cl} 0.90$ to $1.07 ; 572$ participants, four studies; RR $1.03,95 \% \mathrm{Cl} 0.90$ to $1.17 ; 296$ participants, two studies; respectively). Antibiotic treatment does not led to a lower recurrence during the first and fourth week (RR $1.28,95 \% \mathrm{Cl} 0.68$ to 2.43; 218 participants, one study; low quality evidence) or after the fourth week of treatment (RR $1.00,95 \% \mathrm{Cl} 0.67$ to $1.52 ; 372$ participants, three studies; low quality evidence) in women, but increases the frequency of adverse events (most frequently gastrointestinal symptoms) reported by sexual partners ( $\mathrm{RR} 2.55,95 \% \mathrm{Cl} 1.55$ to $4.18 ; 477$ participants, three studies; low quality evidence).

Two trials (172 participants) compared any antibiotic treatment for sexual partners with no intervention. When we compared it with no intervention, the effects of antibiotic treatment on recurrence rate after the fourth week (RR 1.71, 95\% $\mathrm{Cl} 0.65$ to $4.55 ; 51$ participants, one study), clinical improvement between the first and fourth week (RR $0.93,95 \% \mathrm{Cl} 0.70$ to $1.25 ; 152$ participants, two studies) and symptomatic improvement after the fourth week ( $\mathrm{RR} 0.66,95 \% \mathrm{Cl} 0.39$ to $1.11 ; 70$ participants, one study) were imprecise and there were no differences between groups. We downgraded the quality of the evidence to low or very low.

\section{Authors' conclusions}

High quality evidence shows that antibiotic treatment for sexual partners of women with BV, compared with placebo, does not increase the rate of clinical or symptomatic improvement during the first, between the first and fourth or after the fourth week into the women. Low quality evidence suggests that antibiotic treatment does not led to a lower recurrence rate during the first and fourth or after the fourth week of treatment into the women, but increases the frequency of adverse events reported by sexual partners. Finally, compared with no intervention, antibiotic treatment does not decrease the recurrence rate after the fourth week and does not increase the frequency of clinical or symptomatic improvement between the first and fourth or after the fourth week into the women, respectively.

\section{PLAIN LANGUAGE SUMMARY}

\section{Antibiotic treatment for the sexual partners of women with bacterial vaginosis}

\section{Review question}

We assessed the effectiveness in women and the safety in men of concurrent antibiotic treatment for the sexual partners of women treated for bacterial vaginosis (BV).

\section{Background}

Bacterial vaginosis (BV) is an infection that has a prevalence between $10 \%$ to $50 \%$ worlwide. BV results in an imbalance of the normal vaginal flora. Microorganisms associated with BV have been isolated from the normal flora of the male genital tract, and their presence could be related to the recurrence of infection after antibiotic treatment. Therefore, the treatment of sexual partners could offer the advantages of decreasing the recurrence of infection and possibly reducing the burden of the disease.

\section{Trial characteristics}

Cochrane researchers searched the available literature up to the 23 July 2016 and included seven trials with 1026 participants. The trials included sexually-active non-pregnant women between 17 and 56 years of age, either single or married, with symptomatic BV. Four studies only included women involved into a monogamous heterosexual relationship and there was no information about this for the remaining trials. Six trials used 5-nitroimidazoles to treat the sexual partner, four trials used metronidazole and two trials used tinidazole; only one study used a lincosamide for treatment. Five trials compared antibiotic versus placebo (854 participants) and two trials compared antibiotic treatment with no intervention (172 participants). Pharmaceutical companies funded four of the included trials.

\section{Key results}

Compared with placebo, antibiotic treatment for the sexual partners of women treated for BV had no effects on clinical or symptomatic improvement in women, regardless of the time period over which the trials assessed these outcomes (during the first, between the first and fourth, or after the fourth week). Furthermore, antibiotic treatment of the sexual partner may have no effect on the recurrence of BV up to 12 weeks after treatment, but may increase the frequency of minor adverse events reported by sexual partners. Compared with no intervention, treatment of sexual partners of women with BV may have no effect on decreasing the recurrence rate or over the frequency of clinical or symptomatic improvement between the first and fourth or after the fourth week, respectively.

\section{Quality of evidence}

The quality of evidence was high for the outcomes of clinical and symptomatic improvement. The quality of evidence was very low for recurrence due to some limitations regarding risk of bias and imprecision. 


\section{SUMMARY OF FINDINGS}

\section{Summary of findings for the main comparison. Any antibiotic treatment versus placebo}

Any antibiotic treatment versus placebo for the sexual partners of woman with bacterial vaginosis

Patient or population: sexual partners of women with bacterial vaginosis

Setting: outpatient clinic

Intervention: any antibiotic treatment

Comparison: placebo

\begin{tabular}{|c|c|c|c|c|c|}
\hline \multirow[t]{2}{*}{ Outcomes } & \multicolumn{2}{|c|}{ Anticipated absolute effects* $(95 \% \mathrm{Cl})$} & \multirow{2}{*}{$\begin{array}{l}\text { Relative effect } \\
(95 \% \mathrm{Cl})\end{array}$} & \multirow{2}{*}{$\begin{array}{l}\text { Number of partici- } \\
\text { pants } \\
\text { (studies) }\end{array}$} & \multirow{2}{*}{$\begin{array}{l}\text { Quality of the evi } \\
\text { dence } \\
\text { (GRADE) }\end{array}$} \\
\hline & Risk with placebo & $\begin{array}{l}\text { Risk with any antibiotic treat- } \\
\text { ment }\end{array}$ & & & \\
\hline \multirow{2}{*}{$\begin{array}{l}\text { Recurrence } \\
\text { follow-up } 4 \text { to } 12 \text { weeks }\end{array}$} & Study population & & \multirow{2}{*}{$\begin{array}{l}\text { RR } 1.00 \\
\text { (0.67 to } 1.52)\end{array}$} & \multirow{2}{*}{$\begin{array}{l}372 \\
(3 \mathrm{RCTs})\end{array}$} & \multirow{2}{*}{$\begin{array}{l}\oplus \ominus \ominus \ominus \\
\text { very low } 1,2\end{array}$} \\
\hline & 196 per 1000 & $\begin{array}{l}196 \text { per } 1000 \\
\text { (131 to } 297)\end{array}$ & & & \\
\hline \multirow{2}{*}{$\begin{array}{l}\text { Clinical improvement } \\
\text { follow-up } 1 \text { to } 4 \text { weeks }\end{array}$} & Study population & & \multirow{2}{*}{$\begin{array}{l}\text { RR } 1.02 \\
\text { (0.94 to } 1.11)\end{array}$} & \multirow{2}{*}{$\begin{array}{l}590 \\
\text { (3 RCTs) }\end{array}$} & \multirow{2}{*}{$\begin{array}{l}\oplus \oplus \oplus \oplus \\
\text { high }\end{array}$} \\
\hline & 778 per 1000 & $\begin{array}{l}794 \text { per } 1000 \\
\text { (731 to } 864)\end{array}$ & & & \\
\hline \multirow{2}{*}{$\begin{array}{l}\text { Clinical improvement } \\
\text { follow-up } 4 \text { to } 12 \text { weeks }\end{array}$} & Study population & & \multirow{2}{*}{$\begin{array}{l}\text { RR } 0.98 \\
\text { (0.90 to } 1.07)\end{array}$} & \multirow{2}{*}{$\begin{array}{l}572 \\
\text { (4 RCTs) }\end{array}$} & \multirow{2}{*}{$\begin{array}{l}\oplus \oplus \oplus \oplus \\
\text { high }\end{array}$} \\
\hline & 778 per 1000 & $\begin{array}{l}762 \text { per } 1000 \\
\text { (700 to } 832 \text { ) }\end{array}$ & & & \\
\hline \multirow{2}{*}{$\begin{array}{l}\text { Symptomatic improvement } \\
\text { during the first week }\end{array}$} & Study population & & \multirow{2}{*}{$\begin{array}{l}\text { RR } 1.06 \\
\text { (1.00 to } 1.12)\end{array}$} & \multirow{2}{*}{$\begin{array}{l}577 \\
\text { (3 RCTs) }\end{array}$} & \multirow{2}{*}{$\begin{array}{l}\oplus \oplus \oplus \oplus \\
\text { high }\end{array}$} \\
\hline & 863 per 1000 & $\begin{array}{l}914 \text { per } 1000 \\
\text { (863 to } 966 \text { ) }\end{array}$ & & & \\
\hline \multirow{2}{*}{$\begin{array}{l}\text { Symptomatic improvement } \\
\text { follow-up } 1 \text { to } 4 \text { weeks }\end{array}$} & Study population & & \multirow{2}{*}{$\begin{array}{l}\text { RR } 0.93 \\
\text { (0.84 to } 1.03)\end{array}$} & \multirow{2}{*}{$\begin{array}{l}444 \\
(2 \mathrm{RCTs})\end{array}$} & \multirow{2}{*}{$\begin{array}{l}\oplus \oplus \oplus \oplus \\
\text { high }\end{array}$} \\
\hline & 801 per 1000 & $\begin{array}{l}745 \text { per } 1000 \\
\text { (673 to } 825)\end{array}$ & & & \\
\hline \multirow{2}{*}{$\begin{array}{l}\text { Symptomatic improvement } \\
\text { follow-up } 4 \text { to } 12 \text { weeks }\end{array}$} & Study population & & \multirow{2}{*}{$\begin{array}{l}\text { RR } 1.03 \\
\text { (0.90 to } 1.17)\end{array}$} & \multirow{2}{*}{$\begin{array}{l}296 \\
(2 \mathrm{RCTs})\end{array}$} & \multirow{2}{*}{$\begin{array}{l}\oplus \oplus \oplus \oplus \\
\text { high }\end{array}$} \\
\hline & 743 per 1000 & 766 per 1000 & & & \\
\hline
\end{tabular}




\begin{tabular}{|c|c|c|c|c|c|c|}
\hline \multirow{3}{*}{\multicolumn{2}{|c|}{ 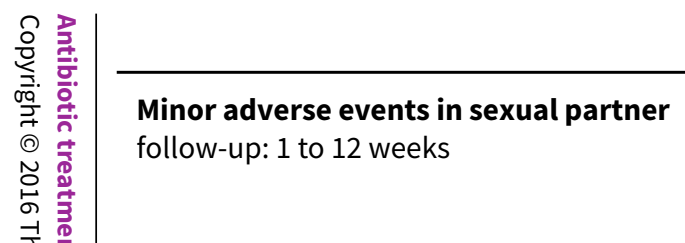 }} & \multicolumn{2}{|r|}{ (669 to 870$)$} & & & \\
\hline & & \multicolumn{2}{|c|}{ Study population } & \multirow{2}{*}{$\begin{array}{l}\text { RR } 2.55 \\
\text { (1.55 to } 4.18 \text { ) }\end{array}$} & \multirow{2}{*}{$\begin{array}{l}477 \\
\text { (3 RCTs) }\end{array}$} & \multirow{2}{*}{$\begin{array}{l}\oplus \oplus \oplus \ominus \\
\text { low }^{3}\end{array}$} \\
\hline & & 80 per 100 & $\begin{array}{l}204 \text { per } 1000 \\
\text { (124 to } 335)\end{array}$ & & & \\
\hline 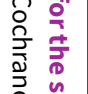 & \multicolumn{6}{|c|}{$\begin{array}{l}\text { *The risk in the intervention group (and its } 95 \% \mathrm{Cl} \text { ) is based on the assumed risk in the comparison group and the relative effect of the intervention (and its } 95 \% \mathrm{CI} \text { ). } \\
\text { Abbreviations: } \mathrm{Cl} \text { : confidence interval; RR: risk ratio; OR: odds ratio. }\end{array}$} \\
\hline 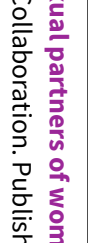 & \multicolumn{6}{|c|}{$\begin{array}{l}\text { GRADE Working Group grades of evidence } \\
\text { High quality: we are very confident that the true effect lies close to that of the estimate of the effect. } \\
\text { Moderate quality: we are moderately confident in the effect estimate: The true effect is likely to be close to the estimate of the effect, but there is a possibility that it is sub- } \\
\text { stantially different. } \\
\text { Low quality: our confidence in the effect estimate is limited: The true effect may be substantially different from the estimate of the effect. } \\
\text { Very low quality: we have very little confidence in the effect estimate: The true effect is likely to be substantially different from the estimate of effect. }\end{array}$} \\
\hline 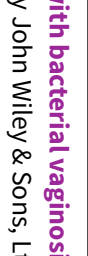 & \multicolumn{6}{|c|}{$\begin{array}{l}\text { 1Downgraded by } 1 \text { level for significant imprecision as the } 95 \% \mathrm{Cl} \text { was below } 0.75 \text { and over } 1.25 \text {. } \\
\text { 2Downgraded by } 2 \text { levels for imprecision as the } 95 \% \mathrm{Cl} \text { crosses through } 0.75 \text { and } 1.25 \text { and OIS is not achieved. } \\
\text { 3Downgraded by } 2 \text { levels for imprecision because the Optimal information size (OIS) was not achieved. }\end{array}$} \\
\hline$\stackrel{\widetilde{D}}{\leq}$ & \multicolumn{6}{|c|}{ Any antibiotic treatment versus no intervention } \\
\hline$\xi$ & \multicolumn{6}{|c|}{$\begin{array}{l}\text { Patient or population: sexual partners of women with bacterial vaginosis } \\
\text { Setting: outpatient clinic } \\
\text { Intervention: any antibiotic treatment } \\
\text { Comparison: no intervention }\end{array}$} \\
\hline & \multirow[t]{2}{*}{ Outcomes } & \multicolumn{2}{|c|}{ Anticipated absolute effects ${ }^{*}(95 \% \mathrm{Cl})$} & \multirow{2}{*}{$\begin{array}{l}\text { Relative effect } \\
(95 \% \mathrm{CI})\end{array}$} & \multirow{2}{*}{$\begin{array}{l}\text { Number of partici- } \\
\text { pants } \\
\text { (studies) }\end{array}$} & \multirow{2}{*}{$\begin{array}{l}\text { Quality of the evi- } \\
\text { dence } \\
\text { (GRADE) }\end{array}$} \\
\hline & & ho inter- & Risk with any antibiotic treatment & & & \\
\hline & \multirow{2}{*}{$\begin{array}{l}\text { Recurrence } \\
\text { follow-up } 4 \text { to } 12 \text { weeks }\end{array}$} & \multicolumn{2}{|c|}{ Study population } & \multirow{2}{*}{$\begin{array}{l}\text { RR } 1.71 \\
\text { (0.65 to } 4.55)\end{array}$} & \multirow{2}{*}{$\begin{array}{l}51 \\
(1 \mathrm{RCT})\end{array}$} & \multirow{2}{*}{$\begin{array}{l}\oplus \ominus \odot \odot \\
\text { very low } 1,2\end{array}$} \\
\hline & & .000 & $\begin{array}{l}333 \text { per } 1000 \\
\text { (126 to } 885)\end{array}$ & & & \\
\hline & \multirow{2}{*}{$\begin{array}{l}\text { Clinical improvement } \\
\text { follow-up } 1 \text { to } 4 \text { weeks }\end{array}$} & \multicolumn{2}{|c|}{ Study population } & \multirow{2}{*}{$\begin{array}{l}\text { RR } 0.93 \\
\text { (0.70 to } 1.25 \text { ) }\end{array}$} & \multirow{2}{*}{$\begin{array}{l}152 \\
(2 \mathrm{RCTs})\end{array}$} & \multirow{2}{*}{$\begin{array}{l}\oplus \ominus \ominus \ominus \\
\text { very low } 1,2,3\end{array}$} \\
\hline & & .000 & 792 per 1000 & & & \\
\hline
\end{tabular}




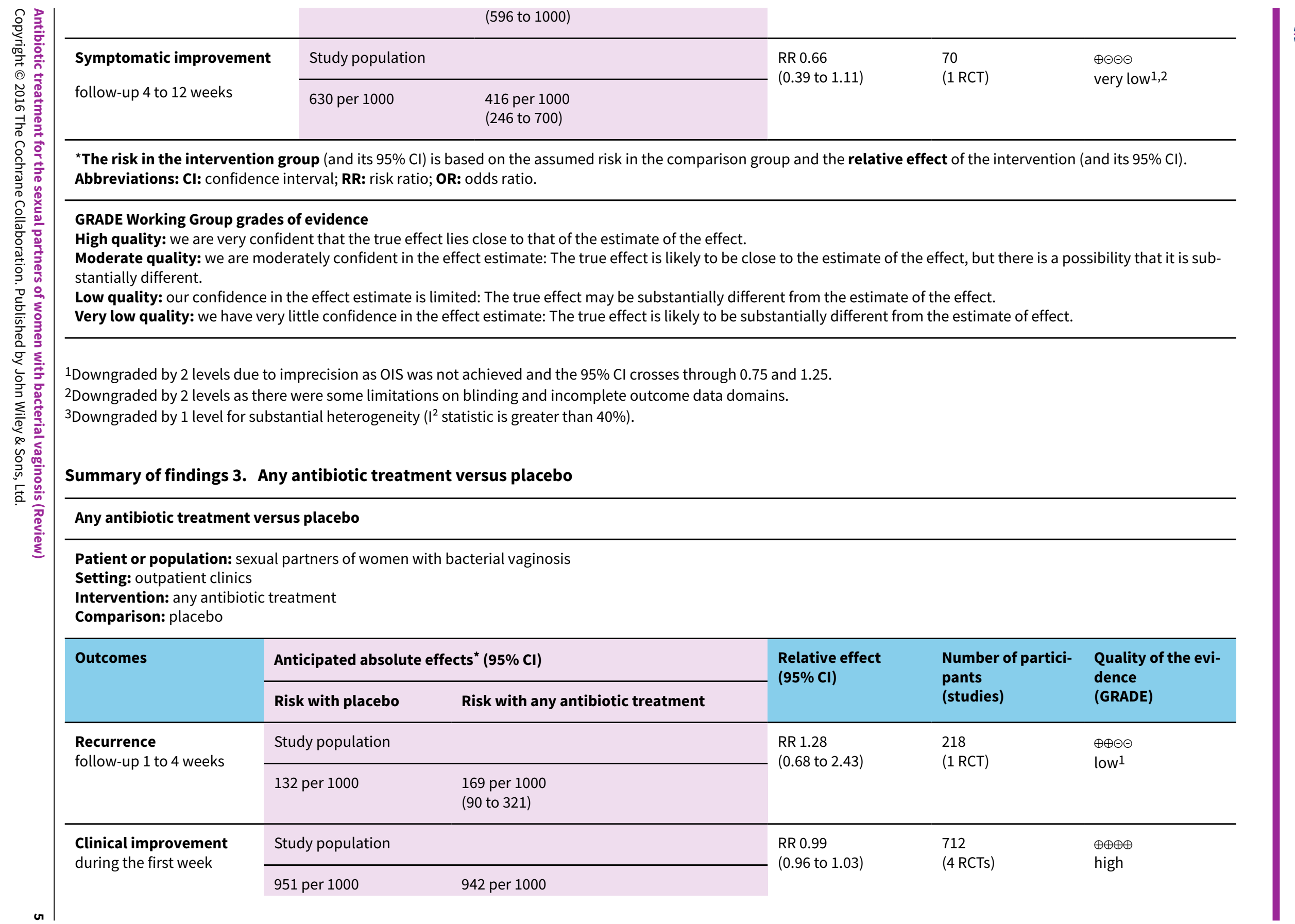


${ }^{*}$ The risk in the intervention group (and its $95 \% \mathrm{Cl}$ ) is based on the assumed risk in the comparison group and the relative effect of the intervention (and its $95 \% \mathrm{Cl}$ ). Abbreviations: Cl: confidence interval; RR: risk ratio; OR: odds ratio.

\section{GRADE Working Group grades of evidence}

High quality: we are very confident that the true effect lies close to that of the estimate of the effect.

Moderate quality: we are moderately confident in the effect estimate: The true effect is likely to be close to the estimate of the effect, but there is a possibility that it is substantially different.

Low quality: our confidence in the effect estimate is limited: The true effect may be substantially different from the estimate of the effect.

Very low quality: we have very little confidence in the effect estimate: The true effect is likely to be substantially different from the estimate of effect.

1Downgraded by 2 levels for imprecision as the $95 \% \mathrm{Cl}$ crosses through 0.75 and 1.25 and OIS is not achieved. 


\section{B A C K G R O U N D}

\section{Description of the condition}

Secretions from the vagina (known as vaginal discharge) are a normal occurrence and result from cervical secretion and other components derived from micro-organisms that colonize the vaginal flora, mostly lactobacilli (Mylonas 2011). Lactobacilli play a predominant role in vaginal homeostasis through the production of lactic acid, hydrogen peroxide and bacteriocins, which are compounds that control the overgrowth of pathogenic micro-organisms (Taylor 2013). An increase in the amount of vaginal discharge is usually associated with the presence of a genital tract infection (Mylonas 2011). Women with an abnormal vaginal discharge most commonly have bacterial vaginosis (BV) $(39.6 \%)$ or, less frequently, vulvovaginal candidiasis $(11 \%)$ or trichomoniasis (0.8\%); however, the exact etiology of the vaginal discharge can change according to the population (Ángel-Müller 2012). BV is thought to arise as a result of an imbalance in the normal vaginal flora when lactobacilli decrease in concentration and are replaced by anaerobic and facultative aerobic bacteria (Taylor 2013), such as Gardnerella vaginalis (40\%) or, less frequently, by Mycoplasma hominis, Clostridia (Mirmonsef 2012), Peptostreptococcus or Mobiluncus (Mylonas 2011). Although the precise cause of this dysbacteriosis is not completely understood, some factors, such as high sexual activity, a new sexual partner and risky sexual behavior (Bradshaw 2005; Mirmonsef 2012; Mylonas 2011), could contribute to this condition (Mylonas 2011).

BV is found worldwide with a prevalence between $10 \%$ and $50 \%$, and is usually higher among sex workers, the HIV-positive population, black and Hispanic women (Kenyon 2013), and among women with a new or a high number of sexual partners (Marrazzo 2011). Having three or more male sexual partners in the past 12 months has been identified as a risk factor for BV (Marrazzo 2011). Also, having a female sexual partner has been reported to increase the risk of BV by $60 \%$ (Smart 2004). The burden of BV is related not only to the prevalence of the condition, but also to a reduction in quality of life, as well as to anxiety and selfconscious feelings relating to the fear of exclusion due to the foul smell associated with the infection (Bilardi 2013). The bacteria associated with BV may be carried by male genitalia, but men are usually asymptomatic (Nelson 2012). The direct cost of BV care has been evaluated in pregnant women, and is particularly related to the complications of pregnancy that derive from it: in a study evaluating a population from the USA, the Netherlands and the UK it was estimated that the overall cost of BV was around one thousand million USD a year (Oleen-Burkey 1995). BV has also been associated with a risk of acquiring a sexually transmitted infection (STI), such as pelvic inflammatory disease (Mirmonsef 2012; Taylor 2013), and infections caused by Neisseria gonorrhoeae, Chlamydiia trachomatis and HIV (Mirmonsef 2012), and with a higher risk of developing cervical cancer (Gillet 2012), and even subfertility (Taylor 2013). In addition, BV may increase the risk of adverse perinatal outcomes, such as low birth weight, preterm delivery and very low birth weight (Sangkomkamhang 2008), and may result in approximately 80,000 excess preterm births every year in the USA (Goldenberg 2005).

The Amsel criteria and Gram staining can be used to diagnose BV, and Gram staining is considered the gold standard for this purpose (Workowski 2015). The Nugent scoring system is applied to Gram stains of vaginal smears to visually estimate the numbers of lactobacilli and BV-associated organisms; a Nugent score of zero to three is considered healthy, four to six is intermediate and a score of seven to ten implies the presence of BV (Brotman 2011). This method has a number of disadvantages: a trained professional is required for the interpretation of results and the Gram stain is unable to detect some micro-organisms, such as Ureaplasma and Mycoplasma (Taylor 2013). When Gram staining is not possible, the Amsel criteria provide a good clinical tool for the diagnosis of BV, which requires the presence of at least three of the following four criteria (Taylor 2013).

- Homogeneous, thin, white vaginal discharge.

- Presence of clue cells on microscopic examination.

- A pH greater than 4.5.

- A positive 'whiff test' (a fishy odour after $10 \%$ potassium hydroxide is added).

In vitro cultures for $G$. vaginalis are of limited utility because although cultures in almost all women with a symptomatic infection are positive, $50 \%$ of the cultures from healthy asymptomatic women are also positive (Mylonas 2011). Finally, in some circumstances a diagnosis can be reached through combining the medical history with the clinical characterization of the discharge during a gynaecological examination (Ministerio de Salud y Protección Social 2013). This approach, the syndromic approach, is based on the assumption that genital tract infections share some common symptoms and signs thus making it possible to assign them a specific etiology without the need for a laboratory test (Ministerio de Salud y Protección Social 2013).

BV is not currently considered a STI but it is well-recognized that both have many aspects in common (Morris 2001). Several studies have reported an association between BV and the coexistence of STIs, risky sexual behaviours, young age at first sexual intercourse, sharing sexual toys, and a new or multiple male or female partners (Chavez 2009; Fethers 2008; Fethers 2009; Marrazzo 2005; Morris 2001). Furthermore, BV is unusual in women without a history of sexual contact (Fethers 2009), and its prevalence is less frequent in women who report that they regularly use condoms or have a stable sexual partner (Chavez 2009; Fethers 2008); these findings are consistent with a strong association between BV and sexual activity (Fethers 2009).

Additionally, some studies have proposed that the bacteria associated with BV may be carried by the male genitalia (Nelson 2012), based on the microbiological isolation of the microorganisms associated with this infection in the flora of the penis and urethra in male partners of infected females (Mandar 2013; Nelson 2012). This is particularly notable in uncircumcized males in whom the presence of a major surface of contact could have a major role as a reservoir, and favour the occurrence of an infection after sexual intercourse (Bukusi 2011; Mehta 2012). Bacteria associated with BV have been isolated from the normal flora of the male coronal sulcus and urethra, and could be related to infection in female partners and to the recurrence of infection after treatment (seen in about $20 \%$ of individuals and defined as three or more proven episodes of BV in 12 months) (Colli 1997; Cook 1992). Another mechanism for infection could be the mechanical transfer of perineal enteric bacteria from the flora of the male genitalia through unprotected and protected intercourse (Mandar 2013). 


\section{Description of the intervention}

As BV is considered to arise from an imbalance in the normal vaginal flora (Taylor 2013), treatment includes the administration of antibiotics, such as nitroimidazoles, lincosamides, macrolides (e.g. erythromycin) and, in some circumstances, penicillins (Oduyebo 2009; Workowski 2015), the objective being to eradicate the abnormal vaginal bacterial flora (Mylonas 2011). 5-Nitroimidazole derivatives are available for oral and intravaginal administration (Workowski 2015). These medications are absorbed completely after oral intake and the volume of distribution of these agents approximates to that of total body water because they are associated with a low level of protein binding (Lamp 1999). 5Nitroimidazole derivatives penetrate well into body tissues and fluids, with the exception of the placenta, and are eliminated in the urine after being metabolized in the liver (Brunton 2011; Trevor 2012). The side effects of 5-nitroimidazoles are usually mild and the most common are headache, nausea, dry mouth and a metallic taste (Brunton 2011; Trevor 2012). The regimens recommended for the treatment of BV include metronidazole $500 \mathrm{mg}$ orally twice a day for seven days or metronidazole gel $0.75 \%$ one full applicator $(5 \mathrm{~g})$ intravaginally once a day for five days; tinidazole $2 \mathrm{~g}$ orally once daily for one or two days or $1 \mathrm{~g}$ orally once daily for five days; or secnidazole $1 \mathrm{~g}$ or $2 \mathrm{~g}$ orally in single doses (Oduyebo 2009; Workowski 2015).

Clindamycin, the most representative of the lincosamides, is almost completely absorbed following oral administration (Bouazza 2012), with a half-life of about three hours, and is widely distributed into fluids and tissues (Bouazza 2012; Gatti 1993). More than $80 \%$ of this agent is bound to plasma proteins, primarily a1acid glycoprotein (Flaherty 1996); it is metabolized in the liver by cytochrome P450 3A4 and is excreted in the urine and bile (Trevor 2012; Wynalda 2003, Yasuda 2008). The most common side effects related to the administration of clindamycin include diarrhoea and, in a small number of individuals, pseudomembranous colitis (Gurwith 1977). Rash can occur in about 10\% of individuals; other reactions, such as Stevens-Johnson syndrome, the reversible elevation of transaminases, granulocytopenia, thrombocytopenia and anaphylactic reactions, are less frequent (Brunton 2011). Regimens suggested for the treatment of BV include clindamycin cream $2 \%$ one full applicator $(5 \mathrm{mg})$ intravaginally at bedtime for seven days; clindamycin $300 \mathrm{mg}$ orally twice daily for seven days; or clindamycin ovules $100 \mathrm{mg}$ intravaginally once at bedtime for three days (Workowski 2015).

The serum half-life of erythromycin is approximately two hours (Josefsson 1982; Zuckerman 2011). The drug is metabolized in the liver by cytochrome P450 3A4 and 2\% to $5 \%$ is eliminated in an active form in the urine (Trevor 2012; Zuckerman 2011). Cholestatic hepatitis is the most notable side effect of macrolides and hepatotoxicity has also been observed (Derby 1993). Large doses have been associated with abdominal cramps, nausea, vomiting and diarrhoea (Zuckerman 2011). Among the recognized allergic reactions are fever, eosinophilia and skin eruptions, which may occur alone or in combination; all disappear shortly after therapy is suspended (Brunton 2011). Erythromycin for the treatment of BV is used at a dose of $333 \mathrm{mg}$ oral three times daily for 14 days in combination with metronidazole (Brocklehurst 2013).

Some studies have used the aminopenicillin amoxicillin for the treatment of BV (Amit 2013; Brocklehurst 2013). This agent is a semi-synthetic penicillin with a half-life of almost 80 minutes, which binds to proteins in the plasma and is excreted renally (Brocklehurst 2013). The most important side effects associated with amoxicillin are nausea, vomiting, rash and antibiotic-associated colitis. The use of ampicillin is now generally avoided due to the emergence of ampicillin-resistant bacteria in individuals with BV (Amit 2013).

\section{How the intervention might work}

To date, the evidence regarding whether to treat or not the sexual partner of a woman with BV is inconclusive (Mehta 2013; Potter 1999). As frequently-used antibiotics for treating BV are widely distributed into the fluids and tissues of the human body (Bouazza 2012; Brunton 2011; Gatti 1993; Trevor 2012), the treatment of sexual partners could eliminate the abnormal flora present in the male genital area that may promote relapse in, or reinfection of, women with BV (Bradshaw 2006).

The 5-nitroimidazole derivatives are agents with antiprotozoal and antibacterial properties (Amit 2013). When a 5-nitroimidazole enters the cellular environment, it is reduced by the pyruvate ferredoxin oxidoreductase system present in bacterial mitochondria, which modifies its chemical structure (Amit 2013). Pyruvate ferredoxin oxidoreductase generates adenosine triphosphate (ATP) via the oxidative decarboxylation of pyruvate; in the presence of a structurally modified 5-nitroimidazole, the electrons that would be transferred to hydrogen ions during the generation of ATP are captured by the nitro group (Amit 2013). This disruption of ATP production promotes the formation of intermediate compounds and free radicals that are highly toxic to the bacteria (Brunton 2011). The lincosamides bind to the $50 \mathrm{~S}$ subunit of bacterial ribosomes and consequentially suppress bacterial protein synthesis (Brunton 2011; Trevor 2012). The macrolides (e.g. erythromycin) are bacteriostatic agents that inhibit protein synthesis by binding reversibly to the $50 \mathrm{~S}$ ribosomal subunits of sensitive micro-organisms (Brunton 2011; Trevor 2012).

The administration of any effective and safe intervention to the sexual partner of a woman with BV could offer the advantages of decreasing the recurrence of infection, thus breaking the chain of infection and possibly decreasing the prevalence of STIs, reducing the burden associated with the condition and impacting positively on the sexual and reproductive health of the woman (Mehta 2013).

\section{Why it is important to do this review}

This systematic review is of paramount importance as some studies suggest that BV exhibits a behaviour similar to that of an STI (Potter 1999). However, there is still some uncertainty regarding whether recurrence of $\mathrm{BV}$ in women could be due to a failure to eradicate the causative organism(s) or a consequence of reinfection by the sexual partner (Bradshaw 2006). Currently, the treatment of sexual partners of women with BV is not recommended (Workowski 2015), but this is based on the critical appraisal of individual clinical trials (none of which provide conclusive evidence regarding the efficacy and safety of male sex partner treatment for women with BV (Mehta 2013)) rather than a synthesis of the available clinical evidence (Mehta 2012; Potter 1999). If the treatment of sexual partners were found to reduce the rate of recurrence of $B V$ then this could reduce costs. However, it would need to be weighed against the possible risk of antibiotic resistance that could arise from the additional multiple treatments such a policy would involve. There is therefore a need for high-quality systematic reviews to improve the clinical 
management of BV (Madhivanan 2013). This systematic review will facilitate the synthesis of the current evidence, and recognize its strengths and weakness, address the uncertainty of the current knowledge and make it possible to assess the effectiveness and safety of this intervention.

\section{O B J E C T IVES}

To assess the effectiveness in women and the safety in men of concurrent antibiotic treatment for the sexual partners of women treated for BV.

\section{METHOD S}

\section{Criteria for considering studies for this review Types of studies}

Randomized controlled clinical trials, published and unpublished, that compared the concurrent use of any antibiotic treatment (any concentration, frequency, duration and route) with placebo, no intervention or any other intervention (any concentration, frequency, duration and route) by the sexual partners of women treated for bacterial vaginosis (BV). We excluded quasi-randomized trials because this approach produces effect estimates that indicate more extreme benefits compared with those generated by randomized controlled clinical trials (Higgins 2011). We also excluded cross-over trials and cluster-randomized trials because of the nature of the condition (Higgins 2011).

\section{Types of participants}

The sexual partners (either male or female) of women treated for non-recurrent BV.

\section{Types of interventions}

Any antibiotic treatment (at any concentration, frequency, duration and route) versus one of the following.

- Placebo.

- No intervention.

- Any other intervention different to antibiotic treatment (any concentration, frequency, duration and route).

\section{Types of outcome measures}

\section{Primary outcomes}

- Recurrence of BV in women treated for BV (proportion of participants who were previously healthy following treatment for BV that developed a new episode of BV, according to Amsel's criteria or any other clinical criteria).

- Clinical improvement (according to Amsel's criteria or any other clinical criteria) in women treated for BV.

- Symptomatic improvement defined as the (self-reported) improvement or disappearance of symptoms in women treated for BV.

- Serious adverse events of the intervention (hypersensitivity, pseudomembranous colitis or Stevens-Johnson syndrome) in sexual partners of women treated for BV.

\section{Secondary outcomes}

- Minor adverse events of the intervention during therapy (metallic taste, nausea, vomiting, diarrhoea or headache) in sexual partners of women treated for BV.

- Cost-effectiveness of the intervention.

The primary outcomes (recurrence, clinical and symptomatic improvement) were assessed during the first week, between the first and fourth week and after the fourth week. We assessed adverse events of the intervention during therapy.

\section{Search methods for identification of studies}

We identified as many relevant randomized controlled trials (RCTs) of "antibiotic treatment" for the "sexual partner of the woman being treated for bacterial vaginosis" as possible, irrespective of language of publication, publication date and publication status (published, unpublished, in press or in progress). We used both the electronic searching of bibliographic databases and handsearching, as described in the Cochrane Handbook for Systematic Reviews of Interventions (Higgins 2011).

\section{Electronic searches}

We contacted the Information specialist of the Cochrane Sexually Transmitted Infections Group in order to implement a comprehensive search strategy to identify as many relevant RCTs as possible in the electronic databases. We used a combination of controlled vocabulary (MeSH, Emtree terms, Health Sciences Descriptors -DeCS for its acronym in Spanish-, including exploded terms) and free-text terms (considering spelling variants, synonyms, acronyms and truncation) for "sexual partner of the woman being treated for bacterial vaginosis" and "antibiotic treatment", with field labels, proximity operators and boolean operators. We have listed our search strategies in the 'Appendices' section (Appendix 1; Appendix 2; Appendix 3; Appendix 4; Appendix 5; Appendix 6; Appendix 7).

We searched the following electronic databases.

- Cochrane Sexually Transmitted Infections Group Specialized Register (searched 23 July 2016).

- Cochrane Central Register of Controlled Trials (CENTRAL), Ovid platform (searched from Cochrane Library Issue 1, 1991 to 23 July 2016).

- MEDLINE, Ovid platform (searched from 1946 to 23 July 2016).

- MEDLINE In-Process \& Other Non-Indexed Citations, Ovid platform (searched from 1966 to 23 July 2016).

- MEDLINE Daily Update, Ovid platform (searched from 1966 to 23 July 2016).

- Embase (searched from 1974 to 23 July 2016).

- LILACS (Latin American and Caribbean Health Sciences Literature, IAHx interface; searched from 1982 to 23 July 2016).

For MEDLINE, we used the Cochrane highly sensitive search strategy for identifying RCTs: sensitivity and precision maximizing version (2008 revision), Ovid format (Higgins 2011). We combined the LILACS search strategy with the RCT filter of the IAHx interface.

\section{Searching other resources}

We searched the following resources for additional trials. 
- Trial registers:

- World Health Organization (WHO) International Clinical Trials Registry Platform (ICTRP) portal (apps.who.int/trialsearch/): searched 23 Jul 2016;

- ClinicalTrials.gov (clinicaltrials.gov/): searched 23 July 2016.

- Web of Science ${ }^{\mathrm{TM}}$ : searched from 2001 to 23 July 2016.

We contacted the trial authors of all RCTs we identified by other methods and handsearched the conference proceeding abstracts of the following events.

- International Society for Sexually Transmitted Diseases Research (ISSTDR) (www.isstdr.org/) scientific meetings: 2007, 2009 and 2011.

- British Association for Sexual Health and HIV (BASHH) (www.bashh.org/) scientific meetings: 2004, 2006, 2007 and 2009.

- The International Congress on Infectious Diseases (ICID) (www.isid.org/): 2010 and 2012.

- International Union against Sexually Transmitted Infections (IUSTI) (www.iusti.org/) conferences and meetings: 2011 and 2012.

- International Society for Infectious Diseases (ISID) (www.isid.org/): 2011.
- International Meeting on Emerging Diseases and Surveillance (IMED) (www.isid.org/): 2007, 2009 and 2011.

- Interscience Conference on Antimicrobial Agents and Chemotherapy (ICAAC) (www.icaac.org/): 2011 and 2012.

- International Federation of Gynecology and Obstetrics (FIGO) (www.figo.org/) World Congress: 2012.

We also handsearched previous systematic reviews and other relevant publications on the same topic and the reference lists of all RCTs identified by other methods.

\section{Data collection and analysis}

\section{Selection of studies}

Three review authors (JA-G, DAV-C and EMS-B) independently assessed the titles and abstracts of the records we retrieved from the search strategy for inclusion. Three review authors independently performed the final selection of trials for inclusion and we resolved any disagreements through discussion. We listed all excluded studies and the reasons for exclusion in a "Characteristics of excluded studies" table and we constructed a PRISMA diagram to illustrated the study selection process (Figure $1)$. 
Figure 1. Study flow diagram.

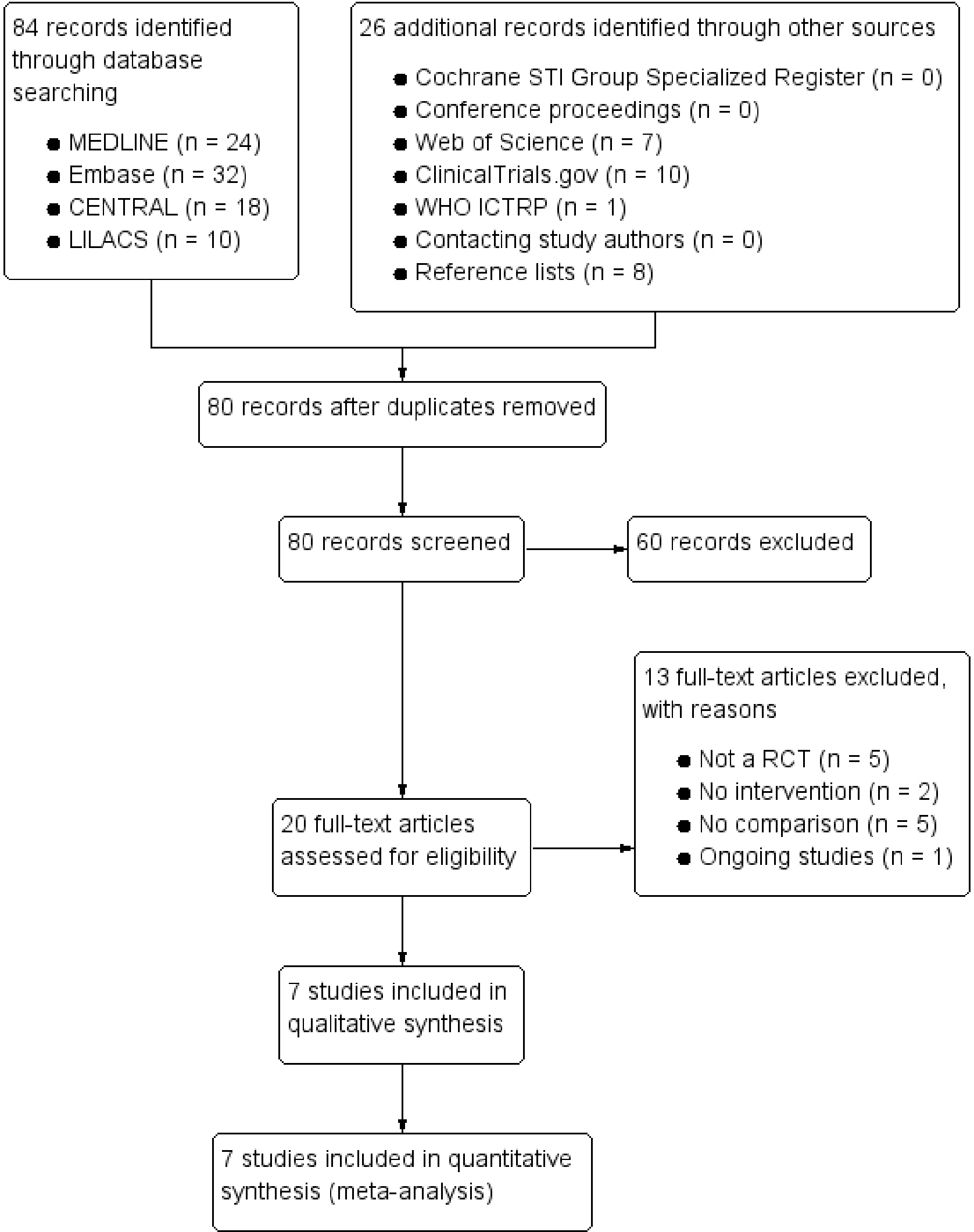




\section{Data extraction and management}

We designed a data extraction form, which we pilot tested with one of the included studies. Three review authors (CFG-A, DAV-C and EMS-B) independently extracted the data from the included studies using the finalized data extraction form. We resolved any disagreements regarding the extracted data through discussion until we reached a consensus.

We extracted data on the following items.

- Location of the trial and setting.

- Trial design.

- Power calculation performed.

- Inclusion and exclusion criteria.

- Baseline information of the participants in order to have comparable intervention groups at entry (age, marital status, contraceptive habits, sexual intercourse during treatment, history of sexually transmitted infections (STIs), sexual behavioral history).

- Total number of intervention groups.

- Types of interventions: antibiotic type (any concentration, frequency, duration and route).

- Types of comparison: placebo, no intervention or any other intervention (any concentration, frequency, duration and route).

- Number of participants enrolled, randomized and excluded after randomization and analysed.

- Number of participants lost to follow-up in the groups.

- Outcomes stated in the methods versus outcomes reported in the results.

- How the trial authors defined the secondary outcomes.

- Differences between groups for outcome assessment.

- Time of follow-up in participants for specific outcomes.

- How the trial authors validated adverse event reports.

- Funding sources reported.

- Ethical issues: use of signed informed consent and ethics approval.

For eligible studies, two review authors (CFG-A and MYM-V) entered the data into Review Manager (RevMan) (RevMan 2014), and checked them for accuracy. When information regarding any of the above was unclear, we contacted authors of the original reports to ask for further details. For a single RCT report, we extracted data directly into a data collection form; in cases of multiple reports, we extracted data from each report separately and then combined information across data collection forms.

\section{Assessment of risk of bias in included studies}

Two review authors (CFG-A and JA-G) independently assessed the risk of bias for each included study using the criteria outlined in the Cochrane Handbook for Systematic Reviews of Interventions (Higgins 2011). We resolved any disagreement by consensus or we consulted a third review author (MYM-V). The review authors that assessed the risk of bias in the included studies were theme and methodology experts. In order to collect missing information, we planned to contact the study investigators using open-ended questions.

\section{Random sequence generation (checking for possible selection bias)}

We described, for each included study, the method used to generate the allocation sequence in sufficient detail to allow an assessment of whether it should produce comparable groups. We assessed the method as follows.

- Low risk of bias (any truly random process, e.g. random number table; computer random number generator).

- High risk of bias (any non-random process, e.g. odd or even date of birth; hospital or clinic record number).

- Unclear risk of bias.

\section{Allocation concealment (checking for possible selection bias)}

For each included study we reported the method used to conceal allocation to interventions prior to assignment and we assessed whether intervention allocation could have been foreseen in advance of, or during, recruitment or changed after assignment. We assessed the methods as follows.

- Low risk of bias (e.g. telephone or central randomization; consecutively numbered sealed opaque envelopes).

- High risk of bias (open random allocation; unsealed or non opaque envelopes, alternation; date of birth).

- Unclear risk of bias.

\section{3a. Blinding of participants and personnel (checking for possible performance bias)}

We described, for each included study, the methods used, if any, to blind study participants and personnel from the knowledge of which intervention a participant received. We considered that studies were at low risk of bias if they were blinded, or if we judged that the lack of blinding would have been unlikely to affect results. We assessed blinding separately for different outcomes or classes of outcomes. We assessed the methods as follows.

- Low, high or unclear risk of bias for participants

- Low, high or unclear risk of bias for personnel.

\section{3b. Blinding of outcome assessment (checking for possible detection bias)}

We described the methods used, if any, to blind outcome assessors from the knowledge of which intervention a participant received for each included study. We assessed blinding separately for different outcomes or classes of outcomes. We also assessed methods used to blind outcome assessment as at either low, high or unclear risk of bias.

\section{Incomplete outcome data (checking for possible attrition bias due to the amount, nature and handling of incomplete outcome data)}

We described, for each included study, and for each outcome or class of outcomes, the completeness of the data including attrition and exclusions from the analysis. We stated whether the trial authors reported attrition and exclusions and the number of participants included in the analysis at each stage (compared with the total number of randomized participants), reasons for attrition or exclusion where reported, and whether missing data were balanced across groups or were related to outcomes. Where an included study reported sufficient information, we re-included 
missing data in the analyses we undertook. We assessed methods as follows.

- Low risk of bias (e.g. no missing outcome data; missing outcome data balanced across groups).

- High risk of bias (e.g. numbers or reasons for missing data imbalance across groups; 'as treated' analysis done with substantial departure of intervention received from that assigned at randomization).

- Unclear risk of bias.

We used a cut-off point of $20 \%$ to determine whether a study was at low or high risk of bias according to the level of missing data.

\section{Selective reporting (checking for reporting bias)}

For each included study, we described how we investigated the possibility of selective outcome reporting bias and what we found. We assessed the methods as follows.

- Low risk of bias (where it was clear that the study authors reported all of the study's prespecified outcomes and all expected outcomes of interest).

- High risk of bias (where the study authors did not report all of the study's prespecified outcomes; the study authors did not prespecify one or more reported primary outcomes; the study authors incompletely reported the outcomes of interest and so we could not used them; the study failed to include the results of a key outcome that we would expected them to have reported).

- Unclear risk of bias.

\section{Other bias (checking for bias due to problems not covered by (1) to (5) above)}

We described, for each included study, any important concerns we had about other possible sources of bias. We assessed whether each included study was free of other problems that could put it at risk of bias. We assessed methods as follows.

- Low risk of other bias.

- High risk of other bias.

- Unclear risk of other bias.

\section{Overall risk of bias}

We made explicit judgments about whether studies were at high risk of bias, according to the criteria given in the Cochrane Handbook for Systematic Reviews of Interventions (Higgins 2011). With reference to (1) to (6) above, we assessed the likely magnitude and direction of the bias and whether we considered it was likely to impact on the findings. We explored the impact of the level of bias by undertaking sensitivity analyses (see the 'Sensitivity analysis' section).

\section{Measures of treatment effect}

\section{Dichotomous data}

For dichotomous data, we reported the results as risk ratios (RRs) with $95 \%$ confidence intervals (Cls). The RR is used as a relative effect measure, which works well with a low or high rate of events, and is easy to interpret and use in clinical practice.

\section{Continuous data}

For continuous data, we used the mean difference if outcomes were measured in the same way between trials. We used the standardized mean difference to combine trials that measured the same outcome but used different methods.

\section{Unit of analysis issues}

The units of analysis were individuals instead of couples. We assessed the effect of the intervention independently in the partner and the woman that constitute the couple. The sexual partner of the woman was randomized to the intervention or comparison group, but all the women included in the study received treatment for BV.

Where we identified a clinical trial that randomized participants to several intervention groups, we determined which intervention groups were relevant. To avoid confusion for the reader, we included all the intervention groups of the study in the 'Characteristics of included studies' table (in the notes cell), and provided a detailed description only of the intervention groups that were relevant to this review, and we only used these groups in our analyses. Finally, in order to overcome a unit-of-analysis error for a study that could contribute multiple correlated comparisons, we combined all relevant experimental intervention groups of the studies into a single group and also combined all relevant control intervention groups into a single control group, in order to create a single pairwise comparison (Higgins 2011).

\section{Dealing with missing data}

We identified the levels of attrition in the included trials and we performed analyses for all outcomes, as far as possible, on an intention-to-treat basis, i.e. we attempted to include all participants randomized to each group in the analyses, and we analysed all participants in the group to which they were allocated, regardless of whether or not they received the allocated intervention. The denominator for each outcome in each trial was the number randomized minus any participants whose outcomes were known to be missing. We explored the impact of including trials with high levels of missing data in the overall assessment of treatment effects by using sensitivity analysis (see the 'Sensitivity analysis' section).

\section{Assessment of heterogeneity}

We assessed statistical heterogeneity in each meta-analysis using the $\mathrm{Tau}^{2}, \mathrm{I}^{2}$ statistic and $\mathrm{Chi}^{2}$ test values (Higgins 2011). We regarded heterogeneity as substantial if the $I^{2}$ statistic value was greater than $40 \%$ and if either the $\mathrm{Tau}^{2}$ value was greater than zero or there was a low $\mathrm{P}$ value (less than 0.10 ) in the $\mathrm{Chi}^{2}$ test for heterogeneity.

\section{Assessment of reporting biases}

We planned to explored publication bias through assessment of funnel plot asymmetry and formal tests. For continuous outcomes, we planned to use the test proposed by Egger 1997, and for dichotomous outcomes we planned to use the test proposed by Harbord 2006. However, we included fewer than 10 trials in the meta-analysis so we did not perform these analyses.

\section{Data synthesis}

We performed statistical analyses using RevMan (RevMan 2014). We used a fixed-effect model to combine data when it was reasonable to assume that studies estimated the same underlying treatment 
effect i.e. where trials examined the same intervention, and we judged the trials' populations and methods to be sufficiently similar. We used a random-effects model if there were clinical heterogeneity sufficient to expect that the underlying treatment effects differed between trials or, if we detected substantial statistical heterogeneity, to produce an overall summary if an average treatment effect across trials was considered clinically meaningful. We treated the random-effects summary as the average range of possible treatment effects and we discussed the clinical implications of treatment effects differing between trials. If the average treatment effect was not clinically meaningful, we did not combine trials.

\section{'Summary of findings' table}

We used the GRADE approach in order to produce a 'Summary of findings' table for the outcomes recurrence after treatment, clinical and symptomatic improvement and minor or serious adverse events (Higgins 2011). We downgraded the quality of evidence depending on the presence of the following factors.

- Study limitations.

- Inconsistency of results.

- Indirectness of evidence.

- Imprecision.

- Publication bias.

\section{Subgroup analysis and investigation of heterogeneity}

We planned explore the following potential sources of heterogeneity using subgroup analyses.

- Comparison of different antibiotic types (5-nitroimidazole, lincosamides or any other antibiotic type).

- Comparison of different durations of antibiotic therapy (single versus multiple doses).

- Comparison of women with monogamous relationships and women with multiple sexual partners.

We restricted subgroup analyses to the primary outcomes:

- Recurrence after treatment into the women.

- Clinical improvement.

- Symptomatic improvement.

Given that the safety and effectiveness of health interventions can differ within and between populations, we proposed a subgroup analysis according to low- versus high-income countries. For fixedeffect inverse variance meta-analyses we assessed differences between subgroups by interaction tests. For fixed-effect metaanalyses using methods other than inverse variance, we assessed differences between subgroups by inspection of the $\mathrm{Cls}$ of the subgroups: non-overlapping $\mathrm{Cls}$ indicate a statistically significant difference in treatment effect between the subgroups.

\section{Sensitivity analysis}

We performed sensitivity analyses based on aspects of the review that may have affected the results; for example, the impact of including trials at high or unclear risk of bias for incomplete outcome data domain. We also carried out a sensitivity analysis to explore the inclusion of the effects of fixed-effect or random-effects analysis for outcomes with statistical heterogeneity.

\section{RES U L T S}

\section{Description of studies}

\section{Results of the search}

We searched the available literature up to 23 July 2016 and retrieved a total of 110 references, of which we screened 80 after we removed duplicates. Of these, we initially screened the full-text articles of 20 references. Seven published trials met our inclusion criteria (Colli 1997; Heikkinen 1989; Mengel 1989; Moi 1989; Swedberg 1985; Vejtorp 1988; Vutyavanich 1993). We excluded 12 studies (see the 'Characteristics of excluded studies' table) and one trial is currently recruiting participants (see the 'Characteristics of ongoing studies' table). We have presented a PRISMA diagram in Figure 1 to illustrate the study selection process.

\section{Included studies}

The seven included trials had a total of 1026 participants and sample sizes ranged from 82 to 250 participants. These trials were from Denmark (Vejtorp 1988), Finland (Heikkinen 1989), Italy (Colli 1997), Thailand (Vutyavanich 1993), the USA (Mengel 1989; Swedberg 1985), and one trial involved the participation of institutions located in four Nordic countries namely Denmark, Finland, Norway and Sweden (Moi 1989). Three trials were multicentric (Colli 1997; Mengel 1989; Moi 1989), only one trial implemented a valid method for sample size calculation (Colli 1997), and all trials included outpatients and were published in English.

\section{Population}

The included studies recruited sexually-active non-pregnant women between 17 and 56 years of age, either single or married, with symptomatic BV. Four studies only included women who were involved into a monogamous heterosexual relationship (Colli 1997; Mengel 1989; Moi 1989; Vutyavanich 1993), and there was no information about this for the remaining trials (Heikkinen 1989; Swedberg 1985; Vejtorp 1988). All included trials used the Amsel's criteria to diagnose the presence of the condition and required the discovery of at least three of these four criteria, in the absence of clinical evidence of mucopurulent

cervicitis, trichomoniasis, genital herpes, papilloma virus or candidiasis. The included studies excluded participants with a recent history of systemic or topical

antibiotic treatment for other condition different to bacterial vaginosis (BV).

There were no restrictions regarding the concurrent use of contraceptive methods during the treatment period, except for Colli 1997, which excluded barrier method users. Four studies specified the contraceptive method at entry (Heikkinen 1989; Moi 1989; Vejtorp 1988; Vutyavanich 1993), and the most frequently used was the birth control pill, followed by intrauterine device, tubal resection and the condom. Two trials allowed sexual activity during the study (Moi 1989; Vutyavanich 1993), while Colli 1997 invited the participants to abstain. The remaining included trials did not mentioned whether sexual intercourse allowed or advised against. Finally, most women were treated with 5-nitroimidazoles, namely the most commonly prescribed metronidazole (Mengel 1989; Moi 1989; Swedberg 1985; Vejtorp 1988), followed by tinidazole (Heikkinen 1989; Vutyavanich 1993). One study used clindamycin cream at bed time (Colli 1997). 


\section{Interventions}

All included trials used the oral route to provide the sexual partner's treatment. The most frequently reported intervention was the use of 5-nitroimidazoles in six studies (Heikkinen 1989; Mengel 1989; Moi 1989; Swedberg 1985; Vejtorp 1988; Vutyavanich 1993). Four of these trials used metronidazole as treatment (Mengel 1989; Moi 1989; Swedberg 1985; Vejtorp 1988), while two trials used tinidazole (Heikkinen 1989; Vutyavanich 1993). Only one study used a lincosamide for treatment (Colli 1997).

The schemes used for metronidazole included $2 \mathrm{~g}$ as a single dose (Mengel 1989; Swedberg 1985), 2 g on day one and day three (Moi 1989; Vejtorp 1988), and $500 \mathrm{mg}$ twice daily for seven days (Swedberg 1985). The included studies that used tinidazole gave a $2 \mathrm{~g}$ single dose (Vutyavanich 1993), or $1 \mathrm{~g}$ for four days (Heikkinen 1989). One study provided clindamycin $150 \mathrm{mg}$ four times daily for seven consecutive days (Colli 1997). None of the included trials assessed the effectiveness of other antibiotic treatments occasionally prescribed in clinical practice, such as aminopenicillins and macrolides.

\section{Comparisons}

Five trials used placebo (Colli 1997; Mengel 1989; Moi 1989; Vejtorp 1988; Vutyavanich 1993). Two trials compared the effectiveness of concurrent antibiotic treatment for the sexual partners with no intervention (Heikkinen 1989; Swedberg 1985).

\section{Outcomes}

None of the primary or secondary outcomes were reported by the totality of the retrieved clinical trials and there were some differences in reporting and definition of the outcomes between trials. Four included studies reported recurrence (Colli 1997; Heikkinen 1989; Moi 1989; Vejtorp 1988), and their presence was established based on the application of Amsel criteria on healthy participants following treatment for BV, with the exception of Moi 1989 , which also required the reappearance of symptoms. Only one study assessed this outcome between the first and fourth week (Moi 1989), and the other three studies assessed for this outcome posterior to the fourth week.

Seven studies reported clinical improvement after treatment (Colli 1997; Heikkinen 1989; Mengel 1989; Moi 1989; Swedberg 1985;
Vejtorp 1988; Vutyavanich 1993), and used the definition of the absence of Amsel's criteria through physical exam plus wet mount. Four trials assessed clinical improvement at the first week (Colli 1997; Moi 1989; Vejtorp 1988; Vutyavanich 1993), five trials assessed this outcome between the first and fourth week (Colli 1997; Heikkinen 1989; Moi 1989; Swedberg 1985; Vutyavanich 1993), and four trials assessed it after the fourth week (Colli 1997; Mengel 1989; Moi 1989; Vejtorp 1988). On the other hand, four studies monitored symptomatic improvement (Heikkinen 1989; Moi 1989; Vejtorp 1988; Vutyavanich 1993). Three trials evaluated symptomatic improvement at the first week (Moi 1989; Vejtorp 1988; Vutyavanich 1993), two trials assessed it between the first and fourth week (Moi 1989; Vutyavanich 1993), and three trials reported it after the fourth week (Heikkinen 1989; Moi 1989; Vejtorp 1988).

Finally, three trials reported the frequency of minor adverse events during treatment. Two of them captured the information through symptoms reported by participants (Colli 1997; Vutyavanich 1993), and the other trial used a questionnaire (Mengel 1989). The minor side effects reported in sexual partners of women treated for BV were the presence of nausea, stomachache, metallic taste and dizziness. We did not obtain any data on the secondary outcomes serious adverse events and cost-effectiveness of the intervention.

\section{Length of follow-up}

There were some differences in length of follow-up between the included studies, which followed participants for either three (Swedberg 1985), four (Vutyavanich 1993), five (Vejtorp 1988), eight (Mengel 1989) or 12 weeks (Moi 1989; Colli 1997; Heikkinen 1989).

\section{Excluded studies}

We excluded 13 studies for the following reasons: 10 studies were not RCTs or did not provide a comparison group (all sexual partners were treated) and two studies did not provide a valid intervention (the sexual partners did not received antibiotic treatment or not all women were treated) (see the 'Characteristics of excluded studies' table). One trial is currently recruiting participants (see the 'Characteristics of ongoing studies' table).

\section{Risk of bias in included studies}

We have summarized the 'Risk of bias' assessment in Figure 2 and Figure 3. Also, we provided additional details of the included trials in the 'Characteristics of included studies' tables. 
Figure 2. 'Risk of bias' graph: review authors' judgements about each 'Risk of bias' item presented as percentages across all included studies.

Random sequence generation (selection bias)

Allocation concealment (selection bias)

Blinding of participants and personnel (performance bias)

Blinding of outcome assessment (detection bias)

Incomplete outcome data (attrition bias)

Selective reporting (reporting bias)

Other bias

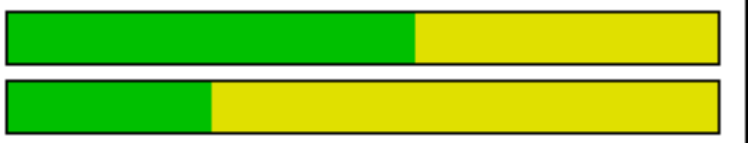

L

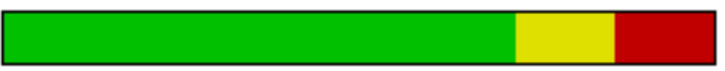

ᄂ

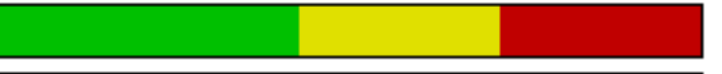

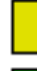

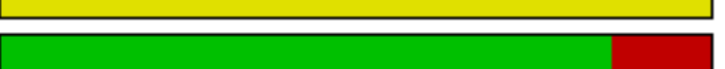

\begin{tabular}{|lllll}
\hline $0 \%$ & $25 \%$ & $50 \%$ & $75 \%$ & $100 \%$
\end{tabular}


Figure 3. 'Risk of bias' summary: review authors' judgements about each 'Risk of bias' item for each included study.

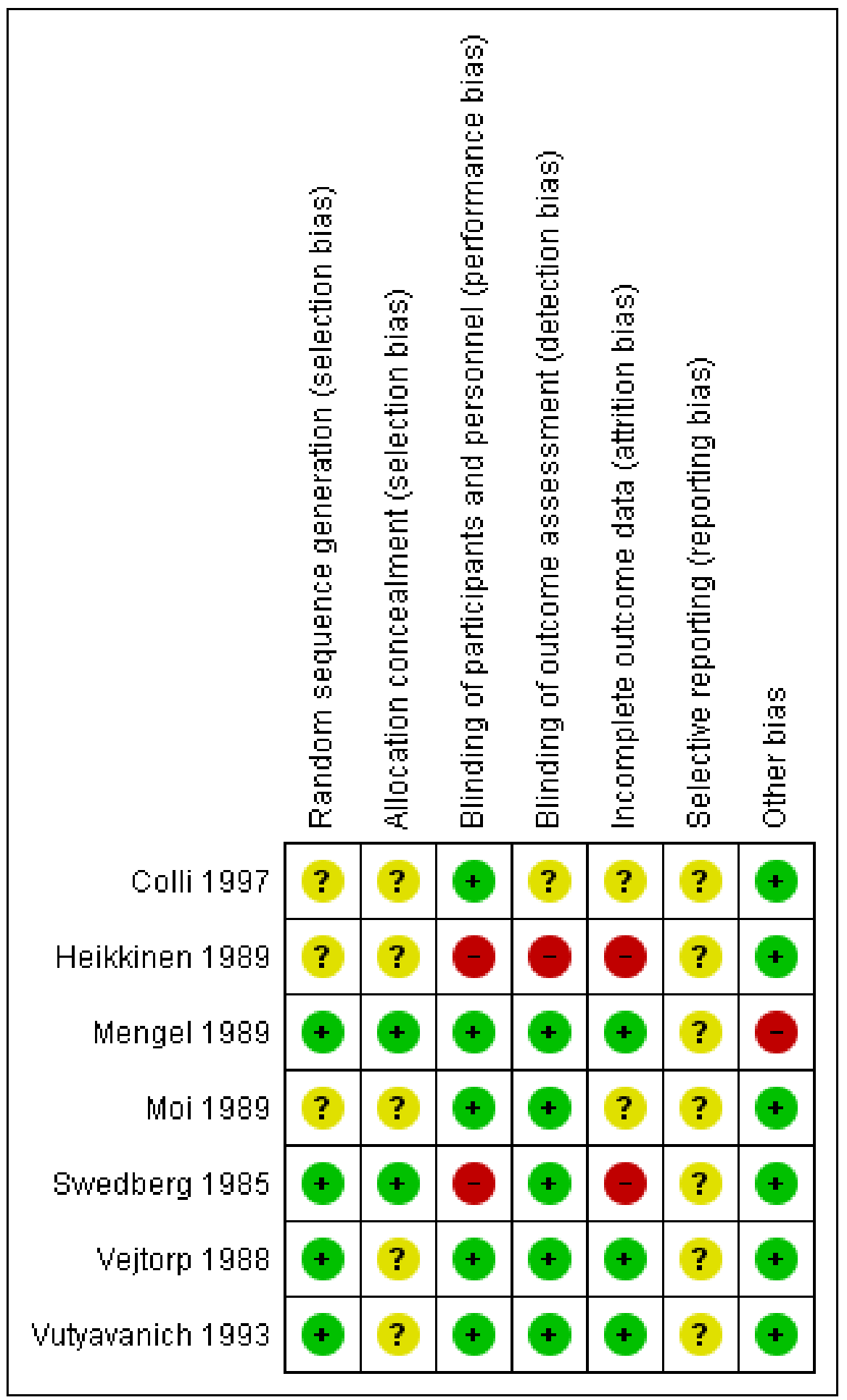

\section{Allocation}

Random sequence generation (checking for possible selection bias)

Four trials adequately reported the random sequence generation method by using a computer-generated randomisation list, so that selection bias at entry was low (Mengel 1989; Swedberg 1985;
Vejtorp 1988; Vutyavanich 1993). The remaining included trials did not report the random sequence generation methods, and the risk of selection bias at entry was unclear (Colli 1997; Heikkinen 1989; Moi 1989).

Antibiotic treatment for the sexual partners of women with bacterial vaginosis (Review) 


\section{Allocation concealment (checking for possible selection bias)}

Two trials adequately implemented a valid allocation concealment method using sequentially numbered drugs containers (Mengel 1989), or by pharmacy-controlled allocation (Swedberg 1985); thus the risk of selection bias at entry in these trials was low. The five remaining included trials did not report the method used to conceal allocation to interventions prior to assignment, and the risk of selection bias at entry was unclear (Colli 1997; Heikkinen 1989; Moi 1989; Vejtorp 1988; Vutyavanich 1993).

\section{Blinding}

Five trials used placebo for the control group to blind trial participants and personnel, and we judged the risk of performance bias as low (Colli 1997; Mengel 1989; Moi 1989; Vejtorp 1988; Vutyavanich 1993). The trial authors assessed two outcomes, recurrence and clinical improvement objectively, in contrast with other outcomes, such as symptomatic improvement and side effects pain, which were subjectively evaluated. However, we judged that the blinding of the outcome assessors from knowledge of which intervention each participant received prevented the risk of detection bias.

The remaining two trials compared the concurrent use of antibiotic treatment with no intervention (Heikkinen 1989; Swedberg 1985). Swedberg 1985 was unblinded to personnel and trial participants and was at high risk of performance bias. However, we appraised the outcome clinical improvement as at low risk of detection bias. This is because it was objectively assessed with Amsel's criteria, and lack of blinding of the outcome assessor was unlikely to affect the results. We considered Heikkinen 1989 as at high risk of performance and detection bias because was unblinded to personnel and trial participants. Also, the outcomes recurrence and symptomatic improvement were subjectively assessed and lack of blinding of the outcome assessor was likely to affect the results. The trial authors objectively assessed the outcome of clinical cure through Amsel's criteria, which made detection bias unlikely for this outcome.

\section{Incomplete outcome data}

Three trials appropriately stated the attrition and exclusions at each stage and the reasons were balanced across groups (Mengel 1989; Vejtorp 1988; Vutyavanich 1993). In addition, the level of missing data was not over $20 \%$ and the attrition or exclusion probably was unrelated to the outcomes, which made attrition bias unlikely.

We assessed two trials as at unclear risk of bias (Colli 1997; Moi 1989). In Colli 1997, we judged the outcomes of clinical cure at 1 , 4 and 12 weeks and gastrointestinal symptoms as at low risk of bias (e.g. no missing outcome data; missing outcome data balanced across groups). However, we assessed the outcome of recurrence as at high risk of bias because the level of missing data was over $20 \%$. Something similar occurred with Moi 1989, where we judged the outcomes of symptomatic improvement and clinical cure at the first and fourth week as at low risk of bias (e.g. no missing outcome data; missing outcome data balanced across groups). However, for the same outcomes at 12 weeks, the risk of bias was high according to the level of missing data (greater than $20 \%$ ).

Two trials had missing data greater that $20 \%$ and did not state the reasons why (Heikkinen 1989; Swedberg 1985); the trial authors conducted the analyses only for those participants who were completely treated (per protocol analysis). We assessed these trials as at high risk of bias.

\section{Selective reporting}

The trial protocol was unavailable for each of the included trials (Colli 1997; Heikkinen 1989; Mengel 1989; Moi 1989; Swedberg 1985; Vejtorp 1988; Vutyavanich 1993). It is unclear whether or not the published reports included all the expected outcomes, including those that were prespecified. The report had insufficient information to permit judgment of "yes" or "no", and we rated this factor as at unclear risk of bias in each of the included trials.

\section{Other potential sources of bias}

Pharmaceutical companies funded four trials (Heikkinen 1989; Moi 1989; Swedberg 1985; Vejtorp 1988), and academic institutions sponsored two trials (Mengel 1989; Vutyavanich 1993). One trial did not mention the funding sources (Colli 1997). We judged one trial, Mengel 1989, as at high risk of bias because of the nature and direction of their results. The remaining studies appeared to be free from other sources of bias.

\section{Effects of interventions}

See: Summary of findings for the main comparison Any antibiotic treatment versus placebo; Summary of findings 2 Any antibiotic treatment versus no intervention; Summary of findings 3 Any antibiotic treatment versus placebo

\section{Any antibiotic treatment versus placebo}

Five trials ( Colli 1997; Mengel 1989; Moi 1989; Vejtorp 1988; Vutyavanich 1993) including 854 participants compared any antibiotic treatment versus placebo. They did not all contribute data to each outcome.

\subsection{Recurrence of BV between the first and fourth week}

Only one trial reported on this outcome (Moi 1989). There was no evidence of significant difference between antibiotic treatment and placebo in the recurrence between first and fourth week of treatment (RR 1.28, 95\% Cl 0.68 to 2.43; 218 participants, one study; Analysis 1.1). The quality of evidence was low due to the limitations of imprecision.

\subsection{Recurrence of BV after the fourth week}

The results correspond to the meta-analysis of three trials (Colli 1997; Moi 1989; Vejtorp 1988). There was no evidence of significant difference between antibiotic treatment and placebo in recurrence of BV after the fourth week of treatment (RR 1.00, 95\% Cl 0.67 to $1.52 ; 372$ participants, three studies; $I^{2}$ statistic $=17 \%$; Analysis 1.2; Figure 4). The quality of the evidence was very low due to the limitations of imprecision. 
Figure 4. Forest plot of comparison: 1 Any antibiotic treatment versus placebo, outcome: 1.2 Recurrence of BV after the fourth week.

\begin{tabular}{|c|c|c|c|c|c|c|c|c|}
\hline \multirow[b]{2}{*}{ Study or Subgroup } & \multicolumn{2}{|c|}{ Antibiotic } & \multicolumn{2}{|c|}{ Placebo } & \multirow[b]{2}{*}{ Weight } & \multirow{2}{*}{$\begin{array}{c}\text { Risk Ratio } \\
\text { M-H, Fixed, 95\% Cl }\end{array}$} & \multirow{2}{*}{$\begin{array}{c}\text { Risk Ratio } \\
\text { M-H, Fixed, 95\% Cl }\end{array}$} & Risk of Bias \\
\hline & Events & Total & Events & Total & & & & $A B C D E F G$ \\
\hline Colli 1997 & 5 & 43 & 9 & 41 & $25.3 \%$ & $0.53[0.19,1.45]$ & $\rightarrow-$ & ? ? $+? ? ?+$ \\
\hline Moi 1989 & 20 & 95 & 15 & 95 & $41.1 \%$ & $1.33[0.73,2.44]$ & & ? ?††? ?† \\
\hline Vejtorp 1988 & 12 & 50 & 12 & 48 & $33.6 \%$ & $0.96[0.48,1.92]$ & & $\odot ? \odot \odot \odot ? \odot$ \\
\hline Total (95\% Cl) & & 188 & & 184 & $100.0 \%$ & $1.00[0.67,1.52]$ & & \\
\hline Total events & 37 & & 36 & & & & & \\
\hline $\begin{array}{l}\text { Heterogeneity: } \mathrm{Chi}^{2}= \\
\text { Test for overall effect }\end{array}$ & $\begin{array}{l}2.41, \mathrm{df}= \\
\mathrm{Z}=0.02\end{array}$ & $\begin{array}{l}2(P= \\
P=0.9\end{array}$ & $\begin{array}{l}0.30) ; 1^{2}= \\
\text { 8) }\end{array}$ & $17 \%$ & & & $\begin{array}{cccc} & 1 & 1 \\
0.005 & 0.1 & 1 & 10 \\
\text { Favours antibiotic } & \text { Favours }\end{array}$ & \\
\hline
\end{tabular}

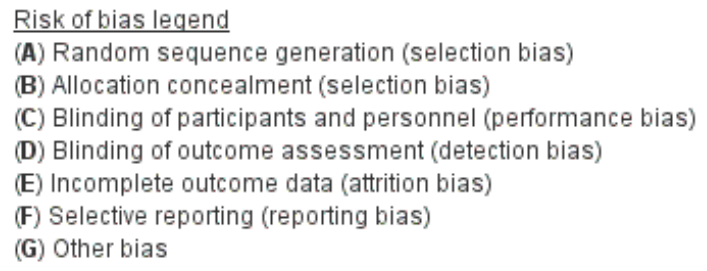

\subsection{Clinical improvement during the first week}

The results correspond to the meta-analysis of four trials (Colli 1997; Moi 1989; Vejtorp 1988; Vutyavanich 1993). There was no

evidence of significant difference in clinical improvement during the first week (RR $0.99,95 \% \mathrm{Cl} 0.96$ to $1.03 ; 712$ participants, four studies; $I^{2}$ statistic = 14\%; Analysis 1.3; Figure 5). The quality of the evidence was high.

Figure 5. Forest plot of comparison: 1 Any antibiotic treatment versus placebo, outcome: 1.3 Clinical improvement during the first week.

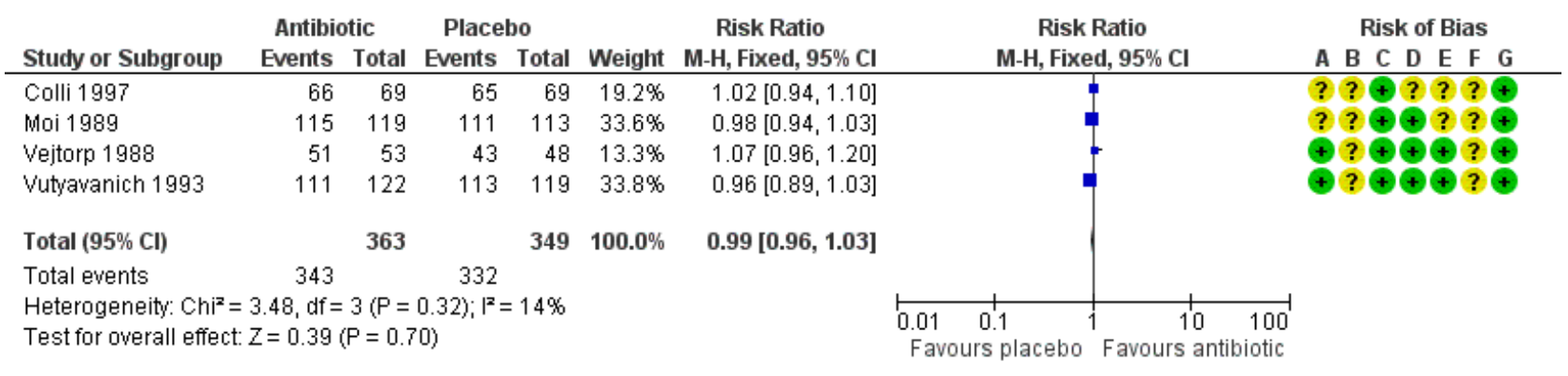

\footnotetext{
Risk of bias legend

(A) Random sequence generation (selection bias)

(B) Allocation concealment (selection bias)

(C) Blinding of participants and personnel (performance bias)

(D) Blinding of outcome assessment (detection bias)

(E) Incomplete outcome data (attrition bias)

(F) Selective reporting (reporting bias)

(G) Other bias
}

\subsection{Clinical improvement between the first and fourth week}

The results correspond to the meta-analysis of three trials (Colli 1997; Moi 1989; Vutyavanich 1993). There was no evidence of significant difference in clinical improvement between the first and fourth week (RR 1.02, 95\% Cl 0.94 to $1.11 ; 590$ participants, three studies; $I^{2}$ statistic = 31\%; Analysis 1.4; Figure 6 ). The quality of the evidence was high. 
Figure 6. Forest plot of comparison: 1 Any antibiotic treatment versus placebo, outcome: 1.4 Clinical improvement between the first and fourth week.

\begin{tabular}{|c|c|c|c|c|c|c|c|c|}
\hline \multirow[b]{2}{*}{ Study or Subgroup } & \multicolumn{2}{|c|}{ Antibiotic } & \multicolumn{2}{|c|}{ Placebo } & \multirow[b]{2}{*}{ Weight } & \multirow{2}{*}{$\begin{array}{c}\text { Risk Ratio } \\
\text { M-H, Fixed, 95\% Cl }\end{array}$} & \multirow{2}{*}{$\begin{array}{c}\text { Risk Ratio } \\
\text { M-H, Fixed, } 95 \% \text { Cl }\end{array}$} & Risk of Bias \\
\hline & Events & Total & Events & Total & & & & A B C D E F G \\
\hline Colli 1997 & 60 & 69 & 62 & 70 & $26.8 \%$ & $0.98[0.87,1.11]$ & 1 & ? ?†??? \\
\hline Moi 1989 & 93 & 112 & 92 & 106 & $41.1 \%$ & $0.96[0.86,1.07]$ & 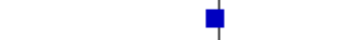 & ? ?†૯? ?† \\
\hline Vutyavanich 1993 & 83 & 116 & 74 & 117 & $32.1 \%$ & $1.13[0.95,1.35]$ & $=$ & $\oplus ?+\odot \odot ? \oplus$ \\
\hline Total $(95 \% \mathrm{Cl})$ & & 297 & & 293 & $100.0 \%$ & $1.02[0.94,1.11]$ & & \\
\hline Total events & 236 & & 228 & & & & & \\
\hline $\begin{array}{l}\text { Heterogeneity: } \mathrm{Chi}^{2}= \\
\text { Test for overall effect }\end{array}$ & $\begin{array}{l}2.88, \mathrm{df}= \\
Z=0.46\end{array}$ & $\begin{array}{l}2(P= \\
P=0.6\end{array}$ & $\begin{array}{l}0.24) ; 1^{2}= \\
5)\end{array}$ & $=31 \%$ & & & $\begin{array}{lll}0.01 & 0.1 & 1\end{array}$ & \\
\hline
\end{tabular}

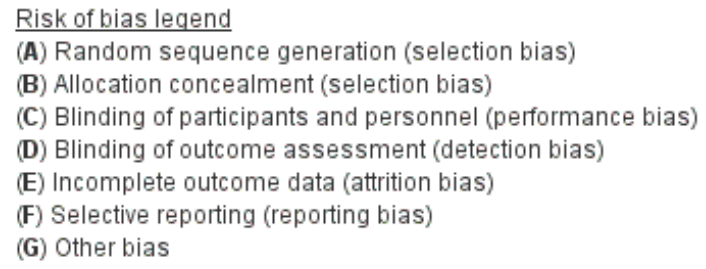

\subsection{Clinical improvement after the fourth week}

The results correspond to the meta-analysis of four trials (Colli 1997; Moi 1989; Vejtorp 1988; Mengel 1989). There was no evidence

of significant difference in clinical improvement after the fourth week (RR 0.98, 95\% Cl 0.90 to $1.07 ; 572$ participants, four studies; $\mathrm{I}^{2}$ statistic $=0 \%$; Analysis 1.5; Figure 7). The quality of the evidence was high.

Figure 7. Forest plot of comparison: 1 Any antibiotic treatment versus placebo, outcome: 1.5 Clinical improvement after the fourth week.

\begin{tabular}{|c|c|c|c|c|c|c|c|c|}
\hline \multirow[b]{2}{*}{ Study or Subgroup } & \multicolumn{2}{|c|}{ Antibiotic } & \multicolumn{2}{|c|}{ Placebo } & \multirow[b]{2}{*}{ Weight } & \multirow{2}{*}{$\begin{array}{c}\text { Risk Ratio } \\
\text { M-H, Fixed, 95\% Cl }\end{array}$} & \multirow{2}{*}{$\begin{array}{c}\text { Risk Ratio } \\
\text { M-H, Fixed, 95\% Cl }\end{array}$} & Risk of Bias \\
\hline & Events & Total & Events & Total & & & & A B C D E F G \\
\hline Colli 1997 & 47 & 69 & 49 & 70 & $21.9 \%$ & $0.97[0.78,1.22]$ & + & ??†? ? ? \\
\hline Mengel 1989 & 55 & 67 & 58 & 71 & $25.3 \%$ & $1.00[0.86,1.18]$ & & $\odot \odot \odot \odot \odot ? \ominus$ \\
\hline Moi 1989 & 75 & 95 & 80 & 95 & $36.0 \%$ & $0.94[0.82,1.07]$ & 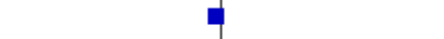 & ? ?††? ?† \\
\hline Vejtorp 1988 & 40 & 53 & 37 & 52 & $16.8 \%$ & $1.06[0.84,1.34]$ & + & $\odot ? \odot \odot \odot ? \odot$ \\
\hline Total $(95 \% \mathrm{Cl})$ & & 284 & & 288 & $100.0 \%$ & $0.98[0.90,1.07]$ & 1 & \\
\hline Total events & 217 & & 224 & & & & & \\
\hline $\begin{array}{l}\text { Heterogeneity: } \mathrm{Chi}^{2}= \\
\text { Test for overall effect }\end{array}$ & $\begin{array}{l}0.97, \mathrm{df}= \\
Z=0.38(\end{array}$ & $\begin{array}{l}3(P=0 \\
(P=0.7\end{array}$ & $\begin{array}{l}0.81) ;\left.\right|^{2}= \\
\text { (1) }\end{array}$ & $=0 \%$ & & & 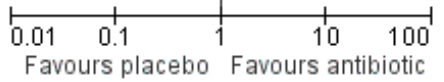 & \\
\hline $\begin{array}{l}\text { Risk of bias leqend } \\
\text { (A) Random sequen } \\
\text { (B) Allocation concea } \\
\text { (C) Blinding of partici } \\
\text { (D) Blinding of outcor } \\
\text { (E) Incomplete outco } \\
\text { (F) Selective reportin } \\
\text { (G) Other bias }\end{array}$ & $\begin{array}{l}\text { e generat } \\
\text { ment (sel } \\
\text { ants and } \\
\text { le assess } \\
\text { ne data (a } \\
\text { (reporting }\end{array}$ & $\begin{array}{l}\text { tion (se } \\
\text { Iection } \\
\text { I person } \\
\text { sment ( } \\
\text { attrition } \\
\text { g bias) }\end{array}$ & $\begin{array}{l}\text { lection bi } \\
\text { bias) } \\
\text { nnel (perf } \\
\text { (detection } \\
\text { bias) }\end{array}$ & $\begin{array}{l}\text { ias) } \\
\text { forman } \\
\text { n bias) }\end{array}$ & ce bias) & & & \\
\hline
\end{tabular}

\subsection{Symptomatic improvement during the first week}

The results correspond to the meta-analysis of three trials (Moi 1989; Vejtorp 1988; Vutyavanich 1993). Antibiotic treatment was not associated with a significant symptomatic improvement during the first week (RR $1.06,95 \% \mathrm{Cl} 1.00$ to $1.12 ; 577$ participants, three studies; $I^{2}$ statistic $=0 \%$; Analysis 1.6 ; Figure 8 ). The quality of the evidence was high. 
Figure 8. Forest plot of comparison: 1 Any antibiotic treatment versus placebo, outcome: 1.6 Symptomatic improvement during the first week.

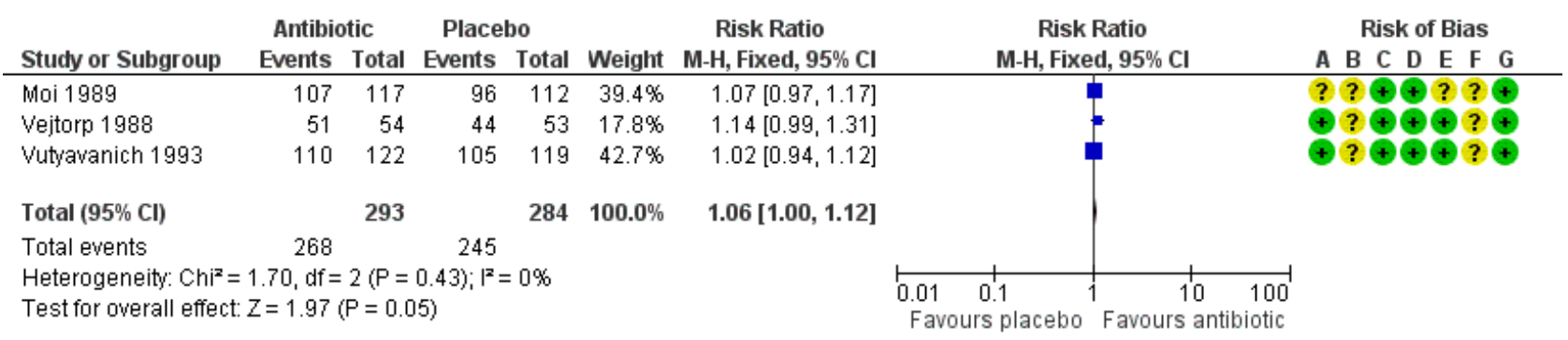

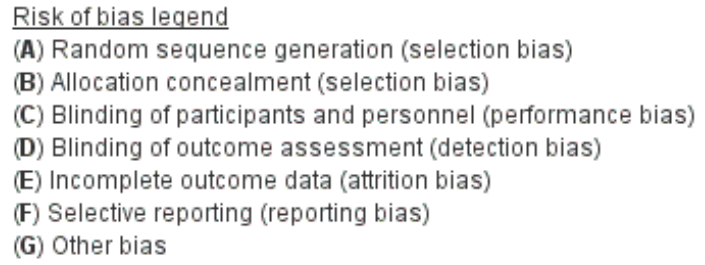

\subsection{Symptomatic improvement between the first and fourth} week

Two trials informed this outcome (Moi 1989; Vutyavanich 1993). There was no evidence of significant difference in this outcome (RR $0.93,95 \% \mathrm{Cl} 0.84$ to $1.03 ; 444$ participants, two studies; $I^{2}$ statistic $=$ $0 \%$; Analysis 1.7). The quality of the evidence was high.

\subsection{Symptomatic improvement after the fourth week}

Two trials informed this outcome (Moi 1989; Vejtorp 1988). There was no evidence of significant difference in this outcome (RR 1.03,
$95 \% \mathrm{Cl} 0.90$ to $1.17 ; 296$ participants, two studies; $\left.\right|^{2}$ statistic $=0 \%$; Analysis 1.8). The quality of the evidence was high.

\subsection{Minor adverse events during therapy in the sexual partner}

The results correspond to the meta-analysis of three trials (Colli 1997; Mengel 1989; Vutyavanich 1993). Antibiotic treatment was associated with a significant minor adverse events report during therapy in sexual partner (RR 2.55, 95\% Cl 1.55 to $4.18 ; 477$ participants, three studies; $I^{2}$ statistic $=0 \%$; Analysis 1.9; Figure 9). The quality of the evidence was low due to the limitations of imprecision.

Figure 9. Forest plot of comparison: 1 Any antibiotic treatment versus placebo, outcome: 1.9 Minor adverse events during therapy in sexual partner.

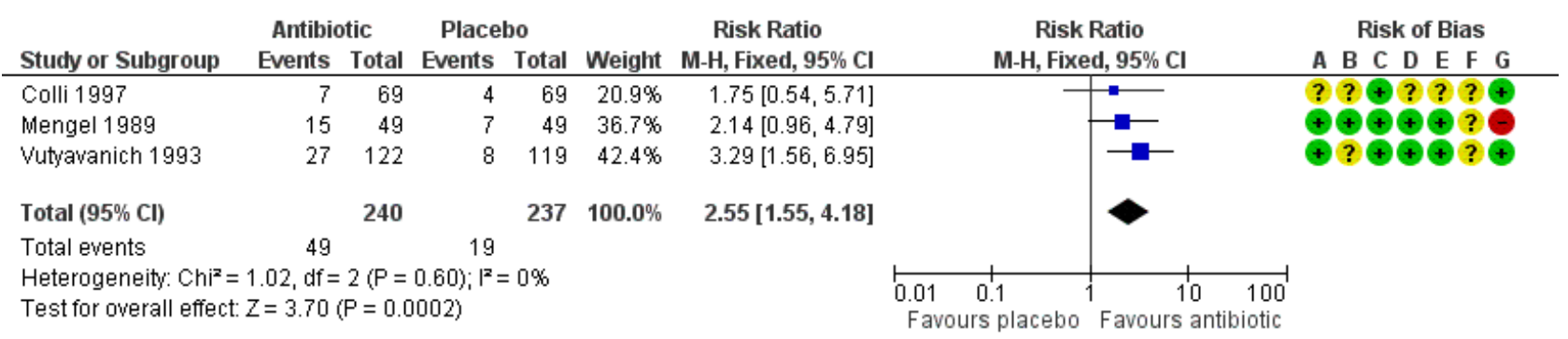

\section{Risk of bias legend}
(A) Random sequence generation (selection bias)
(B) Allocation concealment (selection bias)
(C) Blinding of participants and personnel (performance bias)
(D) Blinding of outcome assessment (detection bias)
(E) Incomplete outcome data (attrition bias)
(F) Selective reporting (reporting bias)
(G) Other bias

\section{Any antibiotic treatment versus no intervention}

Two trials including 172 participants compared the effectiveness of concurrent antibiotic treatment for the sexual partners with no intervention.

\subsection{Recurrence of BV after the fourth week}

One trial informed this outcome (Heikkinen 1989). There was no evidence of statistically significance difference in recurrence of BV after the fourth week (RR $1.71,95 \% \mathrm{Cl} 0.65$ to 4.55 ; 51 participants, one study; Analysis 2.1). The quality of the evidence was very low 
due to the limitations of imprecision, blinding and incomplete outcome data domains.

\subsection{Clinical improvement between the first and fourth week}

Two trials informed this outcome (Heikkinen 1989; Swedberg 1985) There was no evidence of statistically significance difference in this outcome (RR 0.93 , 95\% Cl 0.70 to $1.25 ; 152$ participants, two studies; $I^{2}$ statistic $=62 \%$; Analysis 2.2 ). The quality of the evidence was very low due to the limitations of imprecision, substantial heterogeneity, blinding and incomplete outcome data domains.

\subsection{Symptomatic improvement after the fourth week}

One trial informed this outcome (Heikkinen 1989). There was no evidence of statistically significance difference in symptomatic improvement after the fourth week (RR $0.66,95 \% \mathrm{Cl} 0.39$ to $1.11 ; 70$ participants, one study; Analysis 2.3). The quality of the evidence was very low due to the limitations of imprecision, blinding and incomplete outcome data domains.

\section{Subgroup analysis and investigation of heterogeneity}

We performed subgroup analyses to explore the heterogeneity sources that we found in the analyses of "recurrence" for the comparison antibiotic versus placebo. For this analysis we explored whether differences by antibiotic type (5-Nitroimidazoles versus Lincosamides) reduced the heterogeneity in the overall effect size. The tests for subgroup effect were not significantly different when we explored heterogeneity source by antibiotic type (assessed after the fourth week, $P=0.16$, Analysis 3.1). We did not perform subgroup analysis by antibiotic doses (single versus multiple), because the included trials did not provide enough information for this outcome.

In the analyses of "clinical improvement" for the comparison antibiotic versus placebo, neither of the tests for subgroup effect showed evidence of statistically significant differences, analysing by antibiotic type (assessed during first week, $P=0.53$, Analysis 3.2; between the first and fourth week, $\mathrm{P}=0.53$, Analysis 3.3; and after the fourth week, $P=0.92$, Analysis 3.4) or by antibiotic doses (assessed during first week, $P=0.18$, Analysis 4.1; between the first and fourth week, $P=0.12$, Analysis 4.2; and after the fourth week, $P=0.76$, Analysis 4.3). The effects of the intervention for these outcomes did not change according to the intervention characteristics.

In the analyses of "symptomatic improvement" for the comparison antibiotic versus placebo, neither of the tests for subgroup effect showed evidence of statistically significant differences, analysing by antibiotic doses (assessed during first week, $P=0.29$, Analysis 4.4; and between the first and fourth week, $P=0.71$, Analysis 4.5). We did not perform subgroup analysis by antibiotic type because the included trials did not provide the required information for these analyses. However, for the analyses "minor adverse events during therapy" for the same comparison, neither of the tests for subgroup effect showed evidence of statistically significant differences, analysing by antibiotic type $(P=0.49$, Analysis 3.5$)$ or by dose $(P=0.49$, Analysis 4.6).

We did not perform the subgroup analysis according to kind of relationship, because not all of the included trials, provided enough information on these basal conditions. Finally we neither analysed by income classifications (low- versus high-income) because all retrieved studies were performed in a high-income country.

\section{Sensitivity analysis}

We explored the impact of including trials at high or unclear risk of bias for incomplete outcome data domain in the overall assessment of treatment effects. For the comparison antibiotic treatment versus placebo, neither of the test effects showed evidence of statistically significant differences regardless of the outcome assessed (recurrence, clinical or symptomatic improvement and minor adverse events) or the period of time during which it was measured (during the first, between the first and fourth or after the fourth week).

In this sense, we observed the following results for low risk studies.

- Recurrence after the fourth week (RR $0.96,95 \% \mathrm{Cl} 0.48$ to 1.92 98 participants, one study; Vejtorp 1988)

- Clinical improvement during first week (RR 0.99, 95\% Cl 0.93 to $1.05 ; 242$ participants, two studies; $I^{2}$ statistic $=66 \%$; Vejtorp 1988; Vutyavanich 1993); between the first and fourth week (RR $1.13,95 \% \mathrm{Cl} 0.95$ to $1.35 ; 233$ participants, one study; Vutyavanich 1993); and after the fourth week (RR 1.03, 95\% $\mathrm{Cl} 0.90$ to $1.17 ; 243$ participants, two studies; $I^{2}$ statistic $=0 \%$; Mengel 1989; Vejtorp 1988)

- Symptomatic improvement during first week (RR 1.06, 95\% Cl 0.98 to $1.14 ; 348$ participants, two studies; $\mathrm{I}^{2}$ statistic $=40 \%$; Vejtorp 1988; Vutyavanich 1993); between the first and fourth week (RR 0.95, 95\% Cl 0.83 to 1.08; 232 participants, one study; Vutyavanich 1993); and after the fourth week (RR 1.03, 95\% Cl 0.83 to 1.29 ; 107 participants, one study; Vejtorp 1988 ).

- Minor adverse events of the intervention during therapy (RR $2.76,95 \% \mathrm{Cl} 1.60$ to $4.77 ; 339$ participants, two studies; I $^{2}$ statistic =0\%, Mengel 1989; Vutyavanich 1993).

We did not perform a sensitivity analysis for the comparison of antibiotic versus no intervention, because we assessed all of the included trials as at high risk of bias for incomplete outcome data domain.

\section{DISCUSSION}

\section{Summary of main results}

Seven RCTs (1026 participants) met our inclusion criteria of this review, and industry funded four of these trials. Five trials (854 patients) compared any antibiotic treatment for the treatment of sexual partners with placebo. Based on high quality evidence antibiotic treatment does not increase the rate of clinical or symptomatic improvement in women during the first week (risk ratio (RR) 0.99 , 95\% confidence interval $(\mathrm{Cl}) 0.96$ to $1.03 ; 712$ participants, four studies; RR $1.06,95 \% \mathrm{Cl} 1.00$ to $1.12 ; 577$ patients, three studies, respectively), between the first and fourth week (RR $1.02,95 \% \mathrm{Cl} 0.94$ to $1.11 ; 590$ participants, three studies; RR 0.93 , $95 \% \mathrm{Cl} 0.84$ to 1.03 ; 444 participants, two studies; respectively) or after the fourth week (RR $0.98,95 \% \mathrm{Cl} 0.90$ to $1.07 ; 572$ participants, four studies; RR 1.03, 95\% Cl 0.90 to $1.17 ; 296$ participants, two studies; respectively). Antibiotic treatment does not led to a lower recurrence rate during the first and fourth week (RR $1.28,95 \% \mathrm{Cl}$ 0.68 to 2.43 ; 218 participants, one study; low quality evidence) or after the fourth week of treatment (RR $1.00,95 \% \mathrm{Cl} 0.67$ to 1.52 ; 372 participants, three studies; low quality evidence) in women, 
but increases the frequency of adverse events (most frequently gastrointestinal symptoms) reported by sexual partners (RR 2.55, $95 \% \mathrm{Cl} 1.55$ to 4.18 ; 477 participants, three studies; low-certainty evidence) see the 'Summary of findings' tables Summary of findings for the main comparison; Summary of findings 2; Summary of findings 3.

Two trials (172 participants) compared any antibiotic treatment for the sexual partners with no intervention. When we compared it with no intervention, the effects of antibiotic treatment on recurrence rate after the fourth week (RR $1.71,95 \% \mathrm{Cl} 0.65$ to 4.55; 51 participants, one study), clinical improvement between the first and fourth week (RR $0.93,95 \% \mathrm{Cl} 0.70$ to $1.25 ; 152$ participants, two studies) and symptomatic improvement after the fourth week (RR $0.66,95 \% \mathrm{Cl} 0.39$ to $1.11 ; 70$ participants, one study) were imprecise and there were no differences between groups. We downgraded the quality of the evidence to low or very low.

\section{Overall completeness and applicability of evidence}

We conducted a comprehensive search to retrieve all published and unpublished RCTs. We were able to evaluate all primary outcomes except for serious adverse events and the secondary outcome of cost effectiveness of the intervention that were not reported in any trial. The applicability of the evidence into the target population (the sexual partners of women treated for non-recurrent bacterial vaginosis (BV)) is broad because the retrieved trials were conducted in different clinical settings. In this sense, the result of this systematic review can be applied into clinical practice regardless of the marital status, the form of relationship (monogamous or not), the concurrent use of contraceptive methods or the frequency of sexual intercourse during the treatment. On the other hand, the interventions analysed in the review encompass multiple clinical scenarios that are common in current practice: various antibiotic regimens including 5-nitroimidazoles and lincosamides with different schemes single dose, and treatments from two to seven days.

Finally, because the included studies only assessed the safety and effectiveness of the intervention for heterosexual relationships, the results should not be extrapolated to a different population.

\section{Quality of the evidence}

We considered five of the seven included trials to be at low risk of bias. These studies corresponded to the comparison of any antibiotic treatment versus placebo, and consequently with high confidence on the effect estimate for most outcomes. However, for the comparison any antibiotic treatment versus non-intervention, the confidence on the effect estimate was very low due to trial limitations (lack of blinding and incomplete outcome data), inconsistency (unexplained variability in some results) and some imprecise results (few participants and outcome events with wide Cls). We could not evaluate publication bias, because there were too few included trials into each comparison (see the 'Summary of findings' tables: Summary of findings for the main comparison; Summary of findings 2; Summary of findings 3).

\section{Potential biases in the review process}

This systematic review has many strengths regarding the review process: we adhered to the predefined objectives and study eligibility criteria; our literature search included an appropriate range of databases and sources, including relevant additional methods to identify relevant reports and retrieve as many eligible studies as possible; and we assessed all studies adequately for risk of bias. Two authors performed data extraction independently. However, we have some concerns about publication bias. Publication bias is a possibility because the included trials were mostly funded by industry and due to the limited number of trials for each comparison.

\section{Agreements and disagreements with other studies or reviews}

There are two previous systematic reviews published on this topic (Mehta 2012; Potter 1999). Our review includes one study that the previous two reviews did not include (Heikkinen 1989). The authors of those reviews considered that a meta-analysis could not be conducted due to significant risk of bias in the retrieved studies and by some limitations about heterogeneity; however, these were not a limiting issue for a meta-analysis. Also, as we have shown, the included studies (particularly for the antibiotic treatment versus placebo comparison) are of high quality, there is no significant heterogeneity and we have presented the meta-analyses.

Our conclusions, about the lack of benefit following sexual partner treatment, agree with the recommendation of some important guidelines where this is not recommended (Workowski 2015; van Schalkwyk 2015). However, these recommendations were not based on a systematic and explicit approach.

\section{AUTHORS' CONCLUSIONS}

\section{Implications for practice}

Given the high quality evidence for most outcomes we assessed in this Cochrane Review, there is no benefit of antibiotic treatment compared with placebo for sexual partners of women with BV. Also, there is no increase in the rate of clinical or symptomatic improvement during the first, between the first and fourth or after the fourth week of treatment into the women. There is still some uncertainty due to the low quality of evidence, which suggests that antibiotic treatment does not led to a lower recurrence rate during the first and fourth or after the fourth week of treatment into the women, but increases the frequency of adverse events reported by sexual partners.

\section{Implications for research}

Due to the high quality of evidence for most included outcomes in this Cochrane Review, future studies that evaluate the same outcomes will probably not change our conclusions. However, there is a need for high-quality RCTs that assess recurrence rate adequately, treatment of female partners, treatment for pregnant patients, use of other antibiotic treatments occasionally prescribed in clinical practice such as aminopenicillins and macrolides, and cost effectiveness of interventions. Therefore, study authors should focus their investigations on these problems in the future.

\section{ACKNOWLEDGEMENTS}

As part of the prepublication editorial process, three peers (an editor and two referees who were external to the editorial team), a member of the Sexually Transmitted Infection Group's international panel of consumers and the Group's Statistical Adviser commented on the review draft. 


\section{REFERE N C E S}

\section{References to studies included in this review}

Colli 1997 \{published data only\}

Colli E, Landoni M, Parazzini F. Treatment of male partners and recurrence of bacterial vaginosis: a randomised trial. Genitourinary Medicine 1997;73(4):267-70.

\section{Heikkinen 1989 \{published data only\}}

Heikkinen J, Vuopala S. Anaerobic vaginosis: treatment with tinidazole vaginal tablets. Gynecologic and Obstetric Investigation 1989;28(2):98-100.

\section{Mengel 1989 \{published data only\}}

Mengel MB, Berg AO, Weaver CH, Herman DJ, Herman SJ, Hughes VL, et al. The effectiveness of single-dose metronidazole therapy for patients and their partners with bacterial vaginosis. Journal of Family Practice 1989;28(2):163-71.

\section{Moi 1989 \{published data only\}}

Moi H, Erkkola R, Jerve F, Nelleman G, Bymose B, Alaksen K, et al. Should male consorts of women with bacterial vaginosis be treated?. Genitourinary Medicine 1989;652(4):263-8.

\section{Swedberg 1985 \{published data only\}}

Swedberg J, Steiner JF, Deiss F, Steiner S, Driggers DA. Comparison of single-dose vs one-week course of metronidazole for symptomatic bacterial vaginosis. JAMA 1985;254(8):1046-9.

\section{Vejtorp 1988 \{published data only\}} Vejtorp M, Bollerup AC, Vejtorp L, Fanøe E, Nathan E, Reiter A, et al. Bacterial vaginosis: a double-blind randomized trial of the effect of treatment of the sexual partner. British Journal of Obstetrics and Gynaecology 1988;95(9):920-6.

Vutyavanich 1993 \{published data only\}

Vutyavanich T, Pongsuthirak P, Vannareumol P, Ruangsri RA, Luangsook P. A randomized double-blind trial of tinidazole treatment of the sexual partners of females with bacterial vaginosis. Obstetrics and Gynecology 1993;82 (4 Pt 1):550-4.

\section{References to studies excluded from this review}

\section{Brenner 1986 \{published data only\}}

Brenner WE, Dingfelder JR. Metronidazole-containing vaginal sponges for the treatment of bacterial vaginosis. Advances in Contraception 1986;2(4):363-9.

\section{Bukusi 2011 \{published data only\}}

Bukusi E, Thomas KK, Nguti R, Cohen CR, Weiss N, Coombs RW, et al. Topical penile microbicide use by men to prevent recurrent bacterial vaginosis in sex partners: a randomized clinical trial. Sexually Transmitted Diseases 2011;38(6):483-9.

\section{Eschenbach 1983 \{published data only\}}

Eschenbach DA, Critchlow CW, Watkins H, Smith K, Spiegel CA, Chen KC, et al. A dose-duration study of metronidazole for the treatment of nonspecific vaginosis. Scandinavian Journal of Infectious Diseases. Supplementum 1983;40:73-80.
Giraldo 2013 \{published data only\}

Giraldo PC, Rodrigues HM, Melo AG, do Amaral RL, Passos MRL, Eleuterio $\mathrm{J}$, et al. Vulvovaginitis and the treatment of asymptomatic partners: a systematic review and meta-analysis. Jornal Brasileiro de Doenças Sexualmente Transmissíveis 2013;25(1):36-40.

\section{Hagström 1983 \{published data only\}}

Hagström B, Lindstedt J. Comparison of two different regimens of metronidazole in the treatment of non-specific vaginitis. Scandinavian Journal of Infectious Diseases. Supplementum 1983;40:95-6.

\section{Høvik 1983 \{published data only\}}

Høvik P. Nonspecific vaginitis in an outpatient clinic. Comparison of three dosage regimens of metronidazole. Scandinavian Journal of Infectious Diseases. Supplementum 1983;40:107-10.

\section{Jerve 1984 \{published data only\}}

Jerve F, Berdal TB, Bohman P, Smith CC, Evjen OK, Gjønnaess H, et al. Metronidazole in the treatment of non-specific vaginitis (NSV). British Journal of Venereal Diseases 1984;60(3):171-4.

\section{Koumans 2002 \{published data only\}}

Koumans EH, Markowitz LE, Hogan V, CDC BV Working Group. Indications for therapy and treatment recommendations for bacterial vaginosis in nonpregnant and pregnant women: a synthesis of data. Clinical Infectious Diseases 2002;35(Suppl 2):S152-72.

\section{Larsson 2011 \{published data only\}}

Larsson PG, Brandsborg E, Forsum U, Pendharkar S, Andersen KK, Nasic S, et al. Extended antimicrobial treatment of bacterial vaginosis combined with human lactobacilli to find the best treatment and minimize the risk of relapses. BMC Infectious Diseases 2011;11:223. [DOI: 10.1186/1471-2334-11-223]

Mehta 2012 \{published data only\}

Mehta SD. Systematic review of randomised trials of treatment of male sexual partners for improved bacteria vaginosis outcomes in women. Sexually Transmitted Diseases 2012;39(10):822-30.

\section{Potter 1999 \{published data only\}}

Potter J. Should sexual partners of women with bacterial vaginosis receive treatment?. British Journal of General Practice 1999;49(448):913-8.

\section{Sharma 2005 \{published data only\}}

Sharma JB, Mittal S, Raina U, Chanana C. Comparative efficacy of two regimens in syndromic management of lower genital infections. Archives of Gynecology and Obstetrics 2006;273(4):232-5 


\section{References to ongoing studies}

NCT02209519 \{published data only\}

NCT02209519. Randomized controlled trial of treatment of male partners of women With BV. clinicaltrials.gov/ct2/show/ NCT02209519 (first received 4 August 2014).

\section{Additional references}

\section{Amit 2013}

Amit A, Rawat DS, Rawat MSM. 5-Nitroimidazole derivatives: a scope of modification for medicinal chemists. Research Journal of Chemical Science 2013;3(7):104-13.

\section{Bilardi 2013}

Bilardi JE, Walker S, Temple-Smith M, McNair R, MooneySomers J, Bellhouse $\mathrm{C}$, et al. The burden of bacterial vaginosis: women's experience of the physical, emotional, sexual and social impact of living with recurrent bacterial vaginosis. PLOS One 2013;8(9):e74378.

\section{Bouazza 2012}

Bouazza N, Pestre V, Jullien V, Curis E, Urien S, Salmon D, et al. Population pharmacokinetics of clindamycin orally and intravenously administered in patients with osteomyelitis. British Journal of Clinical Pharmacology 2012;74(6):971-7.

\section{Bradshaw 2005}

Bradshaw CS, Morton AN, Garland SM, Morris MB, Moss LM, Fairley CK. Higher-risk behavioral practices associated with bacterial vaginosis compared with vaginal candidiasis. Obstetrics and Gynecology 2005;106(1):105-14. [PUBMED: 15994624]

\section{Bradshaw 2006}

Bradshaw CS, Morton AN, Hocking J, Garland SM, Morris MB, Moss LM, et al. High recurrence rates of bacterial vaginosis over the course of 12 months after oral metronidazole therapy and factors associated with recurrence. Journal of Infectious Diseases 2006;193(11):1478-86. [PUBMED: 16652274]

\section{Brocklehurst 2013}

Brocklehurst P, Gordon A, Heatley E, Milan SJ. Antibiotics for treating bacterial vaginosis in pregnancy. Cochrane Database of Systematic Reviews 2013, Issue 1. [DOI: 10.1002/14651858.CD000262.pub4]

\section{Brotman 2011}

Brotman RM. Vaginal microbiome and sexually transmitted infections: an epidemiologic perspective. Journal of Clinical Investigation 2011;121(12):4610-7.

\section{Brunton 2011}

Brunton LL, Chabner BA, Knollman BC, editors. Goodman and Gilman's The Pharmacological Basis of Therapeutics. 12th Edition. New York (NY): McGraw-Hill Companies Inc., 2011.

\section{Chavez 2009}

Chavez N, Molina H, Sánchez J, Gelaye B, Sánchez SE. Douches and other risks of bacterial vaginosis [Duchas vaginales y otros riesgos de vaginosis bacteriana]. Revista Peruana de Medicina
Experimental y Salud Pública 2009;26(3):299-306. [PUBMED: 21132048

\section{Cook 1992}

Cook RL, Redondo-Lopez V, Schmitt C, Meriwether C, Sobel JD. Clinical, microbiological and biochemical factors in recurrent bacterial vaginosis. Journal of Clinical Microbiology 1992;30(4):870-7.

\section{Derby 1993}

Derby LE, Jick H, Henry DA, Dean AD. Erythromycinassociated cholestatic hepatitis. Medical Journal of Australia 1993;158(9):600-2.

\section{Egger 1997}

Egger M, Davey Smith G, Schneider M, Minder C. Bias in meta-analysis detected by a simple, graphical test. BMJ 1997;315(7109):629-34.

\section{Fethers 2008}

Fethers KA, Fairley CK, Hocking JS, Gurrin LC, Bradshaw CS. Sexual risk factors and bacterial vaginosis: a systematic review and meta-analysis. Clinical Infectious Diseases 2008;47(11):1426-35. [PUBMED: 18947329]

\section{Fethers 2009}

Fethers KA, Fairley CK, Morton A, Hocking JS, Hopkins C, Kennedy LJ, et al. Early sexual experiences and risk factors for bacterial vaginosis. Journal of Infectious Diseases 2009;200(11):1662-70. [PUBMED: 19863439]

\section{Flaherty 1996}

Flaherty JF Jr, Gatti G, White J, Bubp J, Borin M, Gambertoglio JG. Protein binding of clindamycin in sera of patients with AIDS. Antimicrobial Agents and Chemotherapy 1996;40(5):1134-8.

\section{Gatti 1993}

Gatti G, Flaherty J, Bubp J, White J, Borin M, Gambertoglio J. Comparative study of bioavailabilities and pharmacokinetics of clindamycin in healthy volunteers and patients with AIDS. Antimicrobial Agents and Chemotherapy 1993;37(5):1137-43.

\section{Gillet 2012}

Gillet E, Meys JF, Verstraelen H, Verhelst R, De Sutter P, Temmerman $\mathrm{M}$, et al. Association between bacterial vaginosis and cervical intraepithelial neoplasia: systematic review and meta-analysis. PLoS One 2012;7(10):e45201.

\section{Goldenberg 2005}

Goldenberg RL, Culhane JF, Johnson DC. Maternal infection and adverse fetal and neonatal outcomes. Clinics in Perinatology 2005;32(3):523-59.

\section{GRADEpro}

GRADEpro. [Computer program on www.gradepro.org]. Version [July, 2016]. McMaster University, 2014.

\section{Gurwith 1977}

Gurwith MJ, Rabin HR, Love K. Diarrhea associated with clindamycin and ampicillin therapy: preliminary results of 
a cooperative study. Journal of Infectious Diseases 1977;135 Suppl:S104-10.

\section{Harbord 2006}

Harbord RM, Egger M, Sterne JA. A modified test for smallstudy effects in meta-analyses of controlled trials with binary endpoints. Statistics in Medicine 2006;25(20):3443-57.

\section{Higgins 2011}

Higgins JPT, Green S, editor(s). Cochrane Handbook for Systematic Reviews of Interventions Version 5.1.0 (updated March 2011). The Cochrane Collaboration, 2011. Available from handbook.cochrane.org.

\section{Josefsson 1982}

Josefsson K, Bergan T, Magni L. Dose-related pharmacokinetics after oral administration of a new formulation of erythromycin base. British Journal of Clinical Pharmacology 1982;13(5):685-91.

\section{Kenyon 2013}

Kenyon C, Colebunders R, Crucitti T. The global epidemiology of bacterial vaginosis: a systematic review. American Journal of Obstetrics and Gynecology 2013;209(6):505-23.

\section{Lamp 1999}

Lamp KC, Freeman CD, Klutman NE, Lacy MK. Pharmacokinetics and pharmacodynamics of the nitroimidazole antimicrobials. Clinical Pharmacokinetics 1999;36(5):353-73.

\section{Madhivanan 2013}

Madhivanan P, Barreto GA, Revawala A, Anderson C, McKinney S, Pierre-Victor $D$. Where are we with partner treatment in bacterial vaginosis? A critical appraisal of the latest systematic review. Sexually Transmitted Diseases 2013;40(6):518.

\section{Mandar 2013}

Mandar R. Microbiota of male genital tract: impact on the health of man and his partner. Pharmacological Research 2013;69(1):32-41. [PUBMED: 23142212]

\section{Marrazzo 2005}

Marrazzo J, Coffey P, Bingham A. Sexual practices, risk perception and knowledge of sexually transmitted disease risk among lesbian and bisexual women. Perspectives on Sexual and Reproductive Health 2005;37(1):6-12. [PUBMED: 15888397]

\section{Marrazzo 2011}

Marrazzo JM. Interpreting the epidemiology and natural history of bacterial vaginosis: are we still confused?. Anaerobe 2011;17(4):186-90.

\section{Mehta 2013}

Mehta SD. Response to Madhivanan et al. Sexually Transmitted Diseases 2013;40(6):518-9.

\section{Ministerio de Salud y Protección Social 2013}

Ministerio de Salud y Protección Social - Colciencias. Clinical Practice Guideline for the syndromic approach to the diagnosis and treatment of patients with sexually transmitted infections and other infections of the genital tract. [Guía de práctica clínica para el manejo sindrómico de los pacientes con infecciones de transmisión sexual y otras infecciones del tracto genital]. http:// gpc.minsalud.gov.co/gpc_sites/repositorio/conv_500/GPC_its/ gpc_its.aspx April 2013. Accessed 23/07/2015.

\section{Mirmonsef 2012}

Mirmonsef P, Krass L, Landay A, Spear GT. The role of bacterial vaginosis and trichomonas in HIV transmission across the female genital tract. Current HIV Research 2012;10(3):202-10.

\section{Morris 2001}

Morris MC, Rogers PA, Kinghorn GR. Is bacterial vaginosis a sexually transmitted infection?. Sexually Transmitted Infections 2001;77(1):63-8. [PUBMED: 11158694]

\section{Mylonas 2011}

Mylonas I, Bergauer F. Diagnosis of vaginal discharge by wet mount microscopy: a simple and underrated method. Obstetrical \& Gynecological Survey 2011;66(6):359-68.

\section{Nelson 2012}

Nelson DE, Dong Q, Van der Pol B, Toh E, Fan B, Katz BP, et al. Bacterial communities of the coronal sulcus and distal urethra of adolescent males. PLoS One 2012;7(5):e36298. [PUBMED: 22606251]

\section{Oduyebo 2009}

Oduyebo 00, Anorlu RI, Ogunsola FT. The effects of antimicrobial therapy on bacterial vaginosis in non-pregnant women. Cochrane Database of Systematic Reviews 2009, Issue 3. [DOI: 10.1002/14651858.CD006055.pub2]

\section{Oleen-Burkey 1995}

Oleen-Burkey MA, Hillier SL. Pregnancy complications associated with bacterial vaginosis and their estimated costs. Infectious Diseases in Obstetrics and Gynecology 1995;3(4):14957.

\section{RevMan 2014 [Computer program]}

The Nordic Cochrane Centre, The Cochrane Collaboration. Review Manager (RevMan). Version 5.3. Copenhagen: The Nordic Cochrane Centre, The Cochrane Collaboration, 2014.

\section{Sangkomkamhang 2008}

Sangkomkamhang US, Lumbiganon P, Prasertcharoensook W, Laopaiboon M. Antenatal lower genital tract infection screening and treatment programs for preventing preterm delivery. Cochrane Database of Systematic Reviews 2015, Issue 2. [DOI: 10.1002/14651858.CD006178.pub3]

\section{Smart 2004}

Smart S, Singal A, Mindel A. Social and sexual risk factors for bacterial vaginosis. Sexually Transmitted Infections 2004;80(1):58-62.

\section{Taylor 2013}

Taylor BD, Darville T, Haggerty CL. Does bacterial vaginosis cause pelvic inflammatory disease?. Sexually Transmitted Diseases 2013;40(2):117-22. 


\section{Trevor 2012}

Trevor AJ, Katzung BG, Kruidering-Hall M, Masters SB. Katzung \& Trevor's Pharmacology Examination and Board Review. 10th Edition. New York (NY): McGraw-Hill Companies Inc., 2012.

\section{van Schalkwyk 2015}

van Schalkwyk J, Yudin MH, Infectious Disease Committee. Vulvovaginitis: screening for and management of trichomoniasis, vulvovaginal candidiasis, and bacterial vaginosis. Journal of Obstetrics and Gynaecological Canada 2015;37(3):266-76.

\section{Workowski 2015}

Workowski KA, Bolan GA, Centers for Disease Control and Prevention. Sexually transmitted diseases treatment guidelines, 2015. MMWR Recomm Rep 2015;64(RR-03):1-137.

\section{Wynalda 2003}

Wynalda MA, Hutzler JM, Koets MD, Podoll T, Wienkers LC. In vitro metabolism of clindamycin in human liver and intestinal microsomes. Drug Metabolism and Disposition 2003;31(7):878-87.

\section{Yasuda 2008}

Yasuda K, Ranade A, Venkataramanan R, Strom S, Chupka J, Ekins $S$, et al. A comprehensive in vitro and in silico analysis of antibiotics that activate pregnane $X$ receptor and induce
CYP3A4 in liver and intestine. Drug Metabolism and Disposition 2008;36(8):1689-97.

\section{Zuckerman 2011}

Zuckerman JM, Qamar F, Bono BR. Review of macrolides (azithromycin, clarithromycin), ketolids (telithromycin) and glycylcyclines (tigecycline). Medical Clinics of North America 2011;95(4):761-91.

\section{Ángel-Müller 2012}

Ángel-Müller E, Rodríguez A, Núñez-Forero LM, Moyano LF, González P, Osorio E, et al. The prevalence of and factors associated with C. trachomatis, N. gonorrheae, T. vaginalis, C. albicans infection, syphilis, HIV and bacterial vaginosis in females suffering lower genital tract infection symptoms in three healthcare attention sites in Bogotá, Colombia, 2010. Revista Colombiana de Obstetricia y Ginecología 2012;63(1):25-35.

\section{References to other published versions of this review Amaya 2015}

Amaya-Guio J, Martinez-Velasquez MY, Viveros-Carreño DA, Sierra-Barrios EM, Grillo-Ardila CF. Antibiotic treatment for the sexual partners of women with bacterial vaginosis. Cochrane Database of Systematic Reviews 2015, Issue 5. [DOI: 10.1002/14651858.CD011701]

\section{CHARACTERISTICS OF STUDIES}

Characteristics of included studies [ordered by study ID]

Colli 1997

Methods Setting: Italy, outpatient clinic.

Trial design: multicentre randomized clinical trial, parallel, 2 arms.

Funding sources: not mentioned.

Ethical issues: ethical board and signed consent.

Participants

Age of participants: from 18 to 45 years.

\section{Inclusion criteria:}

sexually-active women with 1 current sexual partner. Clinical diagnosis of bacterial vaginosis (BV and whose partner agreed to be treated. The study authors defined BV as the presence of clue cells on a wet mount slide plus at least 2 of the following.

- Vaginal discharge with $\mathrm{pH}$ greater than 4.5.

- Increased thin homogeneous vaginal discharge that adheres to vaginal walls.

- Release of amine odour from a simple of the discharge after addition of $10 \% \mathrm{KOH}$.

Exclusion criteria: patients treated with systemic or topical antibacterial agents in the 2 weeks before diagnosis of BV; use of intrauterine device or condom; clinical evidence of mucopurulent cervicitis, candidiasis, trichomoniasis, herpes genitalis, papilloma virus, Chlamydia trachomatis, or Neisseria gonorrhoeae infection.

Population

Number of participants: 139 women, 139 men. 
Colli 1997 (Continued)

Baseline characteristics: sexually-active women with 1 current sexual partner. Women were treated with clindamycin $2 \%$ cream, administered intravaginally at bed time for 7 days. Participants were invited to abstain from intercourse during the treatment period and for 1 week after the end of treatment. Most participant couples were married (intervention 66\% versus placebo $75 \%$ ), did not use contraception method (intervention 66\% versus placebo 63\%) and lacked a previous history of pelvic infection (intervention $79 \%$ versus placebo 68\%) or male urethritis (intervention $98 \%$ versus placebo $95 \%$ ).

Total number of intervention groups: Two groups.
Interventions
Iays.
Comparison: placebo.

Outcomes

The trial included evaluation at 1, 4 and 12 weeks after the start of treatment. The participants and their partners had a clinical examination, including the collection of samples of vaginal discharge to check for clue cells, the determination of vaginal $\mathrm{pH}$, and a $\mathrm{KOH}$ test. At both visits, the participant and her partner were asked about medication side effects. The study authors defined cure as the absence of clue cells plus at least 2 of the following: vaginal $\mathrm{pH}$ less than 4.5; negative $10 \% \mathrm{KOH}$ sniff test or grossly normal vaginal discharge (defined as translucent white, flocculent, low volume). The study authors defined recurrence as participants previously healthy after treatment that developed a new episode of BV (Amsel criteria). Participants reported adverse events as symptoms.

Notes None

\section{Risk of bias}

\begin{tabular}{lll}
\hline Bias & Authors' judgement & Support for judgement \\
\hline $\begin{array}{l}\text { Random sequence genera- } \\
\text { tion (selection bias) }\end{array}$ & Unclear risk & $\begin{array}{l}\text { “...This was a double blind, randomised, controlled trial...” } \\
\text { Comment: there was insufficient information to enable us to make a judge- } \\
\text { ment. }\end{array}$ \\
\hline $\begin{array}{l}\text { Allocation concealment } \\
\text { (selection bias) }\end{array}$ & Unclear risk & $\begin{array}{l}\text { Comment: there was insufficient information to enable us to make a judge- } \\
\text { ment. }\end{array}$ \\
\hline $\begin{array}{l}\text { Blinding of participants } \\
\text { and personnel (perfor- } \\
\text { mance bias) } \\
\text { All outcomes }\end{array}$ & Low risk & $\begin{array}{l}\text { The trial authors did not adequately report the method implemented to blind } \\
\text { study participants and personnel from knowledge of which intervention a par- } \\
\text { ticipant received. "The clinicians were blind to the study treatment...” } \\
\text { Comment: this was probably done. }\end{array}$
\end{tabular}

Blinding of outcome as- Unclear risk
sessment (detection bias) All outcomes The trial authors did not adequately report the method implemented to blind
outcome assessment from knowledge of which intervention a participant re-
ceived. Comment: there was insufficient information to enable us to make a
judgement. \begin{tabular}{ll}
$\begin{array}{l}\text { Incomplete outcome data } \\
\text { (attrition bias) }\end{array}$ & Unclear risk \\
All outcomes & $\begin{array}{l}\text { For the outcomes clinical cure at 1, } 4 \text { and } 12 \text { weeks and gastrointestinal symp- } \\
\text { toms the risk of bias was low (e.g. no missing outcome data; missing outcome } \\
\text { data was balanced across groups). However, for the outcome recurrence, the } \\
\text { risk of bias was high according to the level of missing data (greater than 20\%). }\end{array}$ \\
\hline
\end{tabular}

\begin{tabular}{|c|c|c|}
\hline $\begin{array}{l}\text { Selective reporting (re- } \\
\text { porting bias) }\end{array}$ & Unclear risk & $\begin{array}{l}\text { The report did not have sufficient information to permit a judgment of "yes" or } \\
\text { "no". }\end{array}$ \\
\hline
\end{tabular}

Other bias Low risk This study appeared to be free of other sources of bias.


Trial design: single randomized clinical trial, parallel, 2 arms.

Funding sources: Orion pharmaceutical.

Ethical issues: not mentioned.

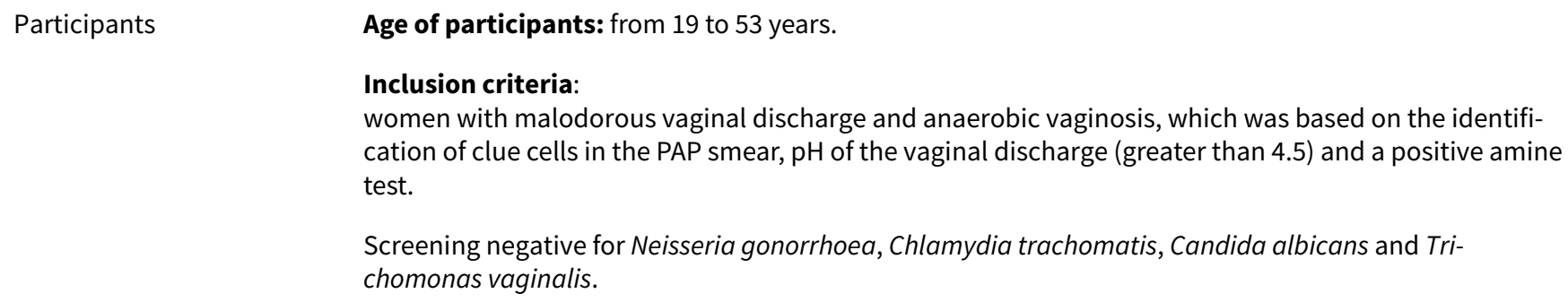

Baseline characteristics: the women were treated with oral tinidazole $500 \mathrm{mg}$ twice a day for 4 days or oral tinidazole $150 \mathrm{mg}$ twice a day for 7 days or intravaginal tinidazole $500 \mathrm{mg}$ at bedtime for 14 days. The trial authors did not provide any more information.

Interventions

Total number of intervention groups:Two groups.

Intervention: oral tinidazol $1 \mathrm{~g}$ for 4 days.

Control: no treatment.

The trial included evaluation at 1 and 3 months after the start of treatment. Women had a clinical ex-
amination, including the collection of PAP smear to check for clue
cells, the determination of vaginal $\mathrm{pH}$, and a
$\mathrm{KOH}$ test.
Cure was defined as the absence of symptoms of BV or absence of clinically verified BV (Amsell criteria)
Relapse was defined as patients who were asymptomatic after treatment and again developed symp-
toms of BV. Adverse events were not reported.

\section{Risk of bias}

\begin{tabular}{lll}
\hline Bias & Authors' judgement & Support for judgement \\
\hline $\begin{array}{l}\text { Random sequence genera- } \\
\text { tion (selection bias) }\end{array}$ & Unclear risk & $\begin{array}{l}\text { "Prospective randomised trial" } \\
\text { Comment: there was insufficient information to enable us to make a judge- } \\
\text { ment. }\end{array}$ \\
\hline $\begin{array}{l}\text { Allocation concealment } \\
\text { (selection bias) }\end{array}$ & Unclear risk & $\begin{array}{l}\text { Comment: there was insufficient information to enable us to make a judge- } \\
\text { ment. }\end{array}$ \\
\hline
\end{tabular}


Heikkinen 1989 (Continued)

Blinding of participants High risk There was no blinding or incomplete blinding, and the outcome or outcome and personnel (performance bias)

All outcomes

\section{Blinding of outcome as- High risk sessment (detection bias)}

All outcomes

$x^{2}$


Mengel 1989 (Continued)

Interventions
Total number of intervention groups: Two groups.

Intervention: $2 \mathrm{~g}$ metronidazole oral single dose.

Comparison: placebo.
The trial included evaluations at 2 and 8 weeks after the onset of the treatment. Women had a clinical examination, including the collection of samples of vaginal discharge to check for clue cells, gram staining and $\mathrm{KOH}$ test; sexual partners were contacted by phone for instructions. At the follow-up visits participants completed a questionnaire on symptoms and medication side effects, and underwent a pelvic examination.

The trial authors defined cure as the absence of at least 3 of the 4 Amsell criteria. They did not define recurrence. Participants reported adverse events as symptoms of BV.

Notes None

\section{Risk of bias}

\begin{tabular}{lll}
\hline Bias & Authors' judgement & Support for judgement \\
\hline $\begin{array}{ll}\text { Random sequence genera- } \\
\text { tion (selection bias) }\end{array}$ & Low risk & $\begin{array}{l}\text { "Randomization was accomplished by blocks of varying sizes (4, } 8 \text { or 12) so } \\
\text { that an equal number of women in each block entered each of the four treat- } \\
\text { ment groups". } \\
\end{array}$ \\
& & Comment: this was probably done. \\
\hline
\end{tabular}

$\begin{array}{ll}\begin{array}{l}\text { Allocation concealment } \\ \text { (selection bias) }\end{array} & \text { "Randomization was accomplished by blocks of varying sizes ( } 4,8 \text { or } 12) \text { so } \\ & \text { that an equal number of women in each block entered each of the four treat- } \\ \text { ment groups" }\end{array}$

Comment: this was probably done. We considered that the authors implemented a valid randomized method which implies that the allocation concealment was probably through the use of consecutively numbered sealed opaque envelopes.

\begin{tabular}{ll}
\hline $\begin{array}{l}\text { Blinding of participants } \\
\text { and personnel (perfor- }\end{array}$ & Low risk \\
$\begin{array}{l}\text { mance bias) } \\
\text { All outcomes }\end{array}$ & $\begin{array}{l}\text { "placebo was used to ensure that both subjects and physicians did not know } \\
\text { the subject's treatment" "metronidazole was identically coloured and shaped }\end{array}$ \\
\end{tabular}

\begin{tabular}{|c|c|c|}
\hline $\begin{array}{l}\text { Blinding of outcome as- } \\
\text { sessment (detection bias) } \\
\text { All outcomes }\end{array}$ & Low risk & $\begin{array}{l}\text { "placebo was used to ensure that both subjects and physicians did not know } \\
\text { the subject's treatment" "metronidazole was identically coloured and shaped } \\
\text { to placebo". The outcomes of cure rate and side effect were objectively as- } \\
\text { sessed. Comment: this was probably done. }\end{array}$ \\
\hline
\end{tabular}

Incomplete outcome data Low risk 20\% or fewer participants were excluded and also intention to treat analyses (attrition bias) was reported.

All outcomes

\begin{tabular}{|c|c|c|}
\hline $\begin{array}{l}\text { Selective reporting (re- } \\
\text { porting bias) }\end{array}$ & Unclear risk & The report had insufficient information to permit a judgment of "yes" or "no". \\
\hline Other bias & High risk & $\begin{array}{l}\text { This trial was supported by grants from the research committee, American } \\
\text { Academy of Family Physicians; Family Health Foundation of America; Washing- } \\
\text { ton Academy of Family Physicians, and the Washington Family Health Founda- } \\
\text { tion. }\end{array}$ \\
\hline
\end{tabular}


Setting: Sweden, Denmark, Finland and Norway. Outpatient clinic.

Trial design: multicentric randomized clinical trial, parallel, 2 arms.

Funding sources: grants from Rhone-Paulenc Pharma Norden AS and Örebro County Council Research Committee.

Ethical issues: ethical board and signed consent.

Age of participants: from 17 to 56 years.
Inclusion criteria:
non-pregnant sexually-active women with 3 of the 4 Amsel criteria. Women had 1 male consort with
whom they had sexual intercourse without using a condom, at least once a week during the study peri-
od.
Exclusion criteria:
pregnancy or lactation; haematological or neurological disease; history of allergy to metronidazole;
antibiotic treatment in the preceding week.
Population
Number of participants: 241 women: 241 men
Baseline characteristics: women were treated with $2 \mathrm{~g}$ metronidazole on days 1 and 3 . A few of the
men were circumcized. Participants were not invited to abstain from intercourse during the treatment
period. Women had 1 male consort with whom they had sexual intercourse without using a condom.
The most frequently used contraception method was oral contraceptives or IUCD.

Interventions

Total number of intervention groups: Two groups.

Intervention: oral metronidazole $2 \mathrm{~g}$, that was repeated 2 days later.

Comparison: placebo.

The trial included evaluation at 1, 4, and 12 weeks after starting treatment. The trial asked participants
about symptoms of BV and had a clinical examination including collection of samples of vaginal dis-
charge to check for odour of the discharge, vaginal $\mathrm{pH}, \mathrm{KOH}$ test and wetness of the vaginal discharge.
The trial authors defined cure as the disappearance of at least 2 previous signs or symptoms reported.
The trial authors defined recurrence as participants who were previously healthy after treatment but
developed a new episode of BV (Amsell criteria). Adverse events were not reported.

Notes None

\section{Risk of bias}

\begin{tabular}{|c|c|c|}
\hline Bias & Authors' judgement & Support for judgement \\
\hline $\begin{array}{l}\text { Random sequence genera- } \\
\text { tion (selection bias) }\end{array}$ & Unclear risk & $\begin{array}{l}\text { "They were randomly allocated to one of two groups for a double blind trial". } \\
\text { Comment: there was insufficient information to make a judgement. }\end{array}$ \\
\hline $\begin{array}{l}\text { Allocation concealment } \\
\text { (selection bias) }\end{array}$ & Unclear risk & Comment: there was insufficient information to make a judgement \\
\hline $\begin{array}{l}\text { Blinding of participants } \\
\text { and personnel (perfor- } \\
\text { mance bias) } \\
\text { All outcomes }\end{array}$ & Low risk & $\begin{array}{l}\text { "They were randomly allocated to one of two groups for a double blind trial", } \\
\text { "Whose male consorts were given inert but identical placebo tablets". } \\
\text { Comment: this was probably done. }\end{array}$ \\
\hline $\begin{array}{l}\text { Blinding of outcome as- } \\
\text { sessment (detection bias) } \\
\text { All outcomes }\end{array}$ & Low risk & $\begin{array}{l}\text { "They were randomly allocated to one of two groups for a double blind trial", } \\
\text { "Whose male consorts were given inert but identical placebo tablets". } \\
\text { Comment: this was probably done. }\end{array}$ \\
\hline
\end{tabular}


Moi 1989 (Continued)

Incomplete outcome data Unclear risk For the outcomes of symptomatic improvement and clinical cure at first and (attrition bias) fourth week the risk of bias was low (e.g. no missing outcome data; missing

All outcomes outcome data balanced across groups). For the same outcomes but assessed at 12 weeks, the risk of bias was high according to the level of missing data (greater than 20\%).

\begin{tabular}{lll}
\hline $\begin{array}{l}\text { Selective reporting (re- } \\
\text { porting bias) }\end{array}$ & Unclear risk & The report had insufficient information to permit judgment of "yes” or “no". \\
\hline Other bias & Low risk & $\begin{array}{l}\text { The trial was sponsored by industry. However, because the results were not } \\
\text { positives, the study would be free of other sources of bias. }\end{array}$
\end{tabular}

Swedberg 1985

Setting: USA, outpatient of family practice clinic.
Trial design: single randomized clinical trial, parallel, 2 arms.
Funding sources: Searle Pharmaceuticals and School of Human Medicine, University of Wyoming.
Ethical issues: ethical board and signed consent.

$\begin{array}{ll}\text { Participants } & \text { Age of participants: from } 18 \text { to } 45 \text { years. } \\ & \text { Inclusion criteria: } \\ \text { non-pregnant women symptomatic for BV; } 3 \text { of the } 4 \text { Amsel criteria; absence of uterine infection, mu- } \\ \text { copurulent cervicitis, trichomoniasis or yeast on microscopic examination. }\end{array}$

\section{Exclusion criteria:}

antibiotics or vaginal cream in the previous 30 days; history of allergy to metronidazole.

\section{Population}

Number of participants: 82 women, 82 men.

Number of participants who received the intervention: 14 (single 2-g dose) and 13 (7-day regimen).

Number of participants who received other(s) intervention(s) or placebo: No treatment was administred to 55 participants, 32 in yhe 2-g single dose group and 23 in the seven day regimen group.

Baseline characteristics: women were treated with metronidazole $500 \mathrm{mg}$ twice a day for 7 days or $2 \mathrm{~g}$ single doses. The trial authors did not provide more information.

$\begin{array}{ll}\text { Interventions } & \text { Total number of intervention groups: Two groups. } \\ \text { Intervention: single oral } 2 \mathrm{~g} \text { or } 500 \mathrm{mg} \text { of metronidazole twice daily for } 7 \text { days. } \\ \text { Comparison: no intervention. }\end{array}$

Outcomes

The trial included evaluation at 7 to 10 and 21 days after starting treatment. All participants had a clinical examination, including the collection of samples of vaginal discharge to check for clue cells, $\mathrm{KOH}$ test, vaginal $\mathrm{pH}$ and cultures for gonorrhoea. At both visits, the participants were evaluated by a Likert-type questionnaire for symptoms of vaginitis (vulvar itching, vulvar burning, odour and quantity of discharge).

Cure was defined if $G$ vaginalis was not isolated on culture and if symptoms had markedly improved or been assent (Likert-type questionnaire). The participants reported adverse events as symptoms.

Notes None


Swedberg 1985 (Continued)

Risk of bias

\begin{tabular}{|c|c|c|}
\hline Bias & Authors' judgement & Support for judgement \\
\hline $\begin{array}{l}\text { Random sequence genera- } \\
\text { tion (selection bias) }\end{array}$ & Low risk & $\begin{array}{l}\text { "Computer generated random number list". } \\
\text { Comments: this was probably done. }\end{array}$ \\
\hline $\begin{array}{l}\text { Allocation concealment } \\
\text { (selection bias) }\end{array}$ & Low risk & $\begin{array}{l}\text { "Regimen dispensed by the clinic pharmacist" } \\
\text { Comment: this was probably done. Telephone or central randomization. }\end{array}$ \\
\hline $\begin{array}{l}\text { Blinding of participants } \\
\text { and personnel (perfor- } \\
\text { mance bias) } \\
\text { All outcomes }\end{array}$ & High risk & $\begin{array}{l}\text { There was no blinding or incomplete blinding, and the outcome or outcome } \\
\text { measurement is likely to have been influenced by a lack of blinding. }\end{array}$ \\
\hline $\begin{array}{l}\text { Blinding of outcome as- } \\
\text { sessment (detection bias) } \\
\text { All outcomes }\end{array}$ & Low risk & $\begin{array}{l}\text { "The clinical practitioner and the laboratory personnel were "blinded" in that } \\
\text { they did not know to which treatment group the patient would be assigned". } \\
\text { Comment: this was probably done. }\end{array}$ \\
\hline $\begin{array}{l}\text { Incomplete outcome data } \\
\text { (attrition bias) } \\
\text { All outcomes }\end{array}$ & High risk & $\begin{array}{l}\text { More than } 20 \% \text { were excluded: " } 18 \text { did no return at } 21 \text { days after treatment, } 14 \\
\text { were excluded because they failed to return at } 7-10 \text { day". }\end{array}$ \\
\hline $\begin{array}{l}\text { Selective reporting (re- } \\
\text { porting bias) }\end{array}$ & Unclear risk & The report had insufficient information to permit judgment of "yes" or "no". \\
\hline Other bias & Low risk & $\begin{array}{l}\text { Searle Pharmaceuticals provided the medication, Other funds for this project } \\
\text { were provided by the School of Human Medicine, University of Wyoming. } \\
\text { Comment: sponsored by industry. However, because the result were not posi- } \\
\text { tives, the study would be free of other sources of bias. }\end{array}$ \\
\hline
\end{tabular}

Vejtorp 1988

Methods Setting: Denmark, outpatient clinic.

Trial design: single randomized clinical trial, parallel, 2 arms.

Funding sources: Rhone-Poulenc Pharma Norden A/S.

Ethical issues: ethical board and sign consent.

Participants

Age of participants: from 17 to 50 years.

Inclusion criteria:

non-pregnant women with 3 of the 4 Amsel criteria.

\section{Exclusion criteria:}

women diagnosed with Candida or trichomonal infection; mucopurulent cervical discharge; tenderness of the uterus or adnexa; adnexal masses.

\section{Population}

Number of participants: 126 women, 126 men. 
Vejtorp 1988 (Continued)

Baseline characteristics: women were treated with $2 \mathrm{~g}$ metronidazole on days 1 and 3. Most participant couples used a contraception method (birth control pill and IUCD). The trial authors did not provide any more information.
Total number of intervention groups: Two groups.

Intervention: metronidazole tablets, $2 \mathrm{~g}$ on days 1 and 3.

Comparison: placebo. The trial included evaluation at 1 and 5 weeks after the start of treatment. The women had a clinical ex-
amination, including the collection of samples of vaginal discharge to check for clue
cells, the determination of vaginal $\mathrm{pH}$, and a
$\mathrm{KOH}$ test. At both visits, the participant and her
partner were asked about medication side effects.
The trial authors defined cure as the absence or symptoms of BV (increased discharge, malodour, burn-
ing sensation or itching) and without at least 3 of the 4 Amsell criteria.

The trial authors defined recurrence as participants that were clinically cured after treatment and then developed a new episode of BV (Amsel criteria).

Adverse events were not reported.

Notes None.

\section{Risk of bias}

\begin{tabular}{lll}
\hline Bias & Authors' judgement & Support for judgement \\
\hline $\begin{array}{ll}\text { Random sequence genera- } \\
\text { tion (selection bias) }\end{array}$ & Low risk & $\begin{array}{l}\text { "The partners were allocated to receive metronidazole or placebo by random } \\
\text { allocation in blocks of four" } \\
\text { Comment: this was probably done. }\end{array}$ \\
\hline
\end{tabular}

\begin{tabular}{lll}
\hline $\begin{array}{l}\text { Allocation concealment } \\
\text { (selection bias) }\end{array}$ & Unclear risk & Comment: there was insufficient information to make a judgement. \\
\hline $\begin{array}{l}\text { Blinding of participants } \\
\text { and personnel (perfor- }\end{array}$ & Low risk & $\begin{array}{l}\text { The trial authors did not adequately report the method implemented to blind } \\
\text { mance bias) }\end{array}$ \\
$\begin{array}{l}\text { stl outcomes } \\
\text { ticipant received. "The women were treated with metronidazole tablets, } 2 \mathrm{~g} \text { on } \\
\text { days } 1 \text { and } 3 . \text { The partner was given the same treatment or a placebo". } \\
\text { Comment: this was probably done. }\end{array}$
\end{tabular}

\begin{tabular}{|c|c|c|}
\hline $\begin{array}{l}\text { Blinding of outcome as- } \\
\text { sessment (detection bias) } \\
\text { All outcomes }\end{array}$ & Low risk & $\begin{array}{l}\text { The trial authors did not adequately report the method implemented to blind } \\
\text { study participants and personnel from knowledge of which intervention a par- } \\
\text { ticipant received. "The women were treated with metronidazole tablets, } 2 \text { g on } \\
\text { days } 1 \text { and } 3 \text {. The partner was given the same treatment or a placebo". } \\
\text { Comment: this was probably done. }\end{array}$ \\
\hline
\end{tabular}

\begin{tabular}{lll}
\hline $\begin{array}{l}\text { Incomplete outcome data } \\
\text { (attrition bias) } \\
\text { All outcomes }\end{array}$ & Low risk & $\begin{array}{l}20 \% \text { or fewer participants were excluded and also intention to treat analyses } \\
\text { was reported. }\end{array}$ \\
\hline $\begin{array}{l}\text { Selective reporting (re- } \\
\text { porting bias) }\end{array}$ & Unclear risk & $\begin{array}{l}\text { The report did not have sufficient information to permit a judgment of "yes" or } \\
\text { no". }\end{array}$ \\
\hline Other bias & Low risk & $\begin{array}{l}\text { Rhone-Poulenc Pharma Norden A/S supported the trial. } \\
\text { Comment: this trial was sponsored by industry. However, because the results } \\
\text { were not positive, the study would be free of other sources of bias. }\end{array}$
\end{tabular}


Trial design: single randomized clinical trial, parallel, 2 arms.

Funding sources: Faculty of Medicine, Chiang Mai University.

Ethical issues: ethical board and signed consent.

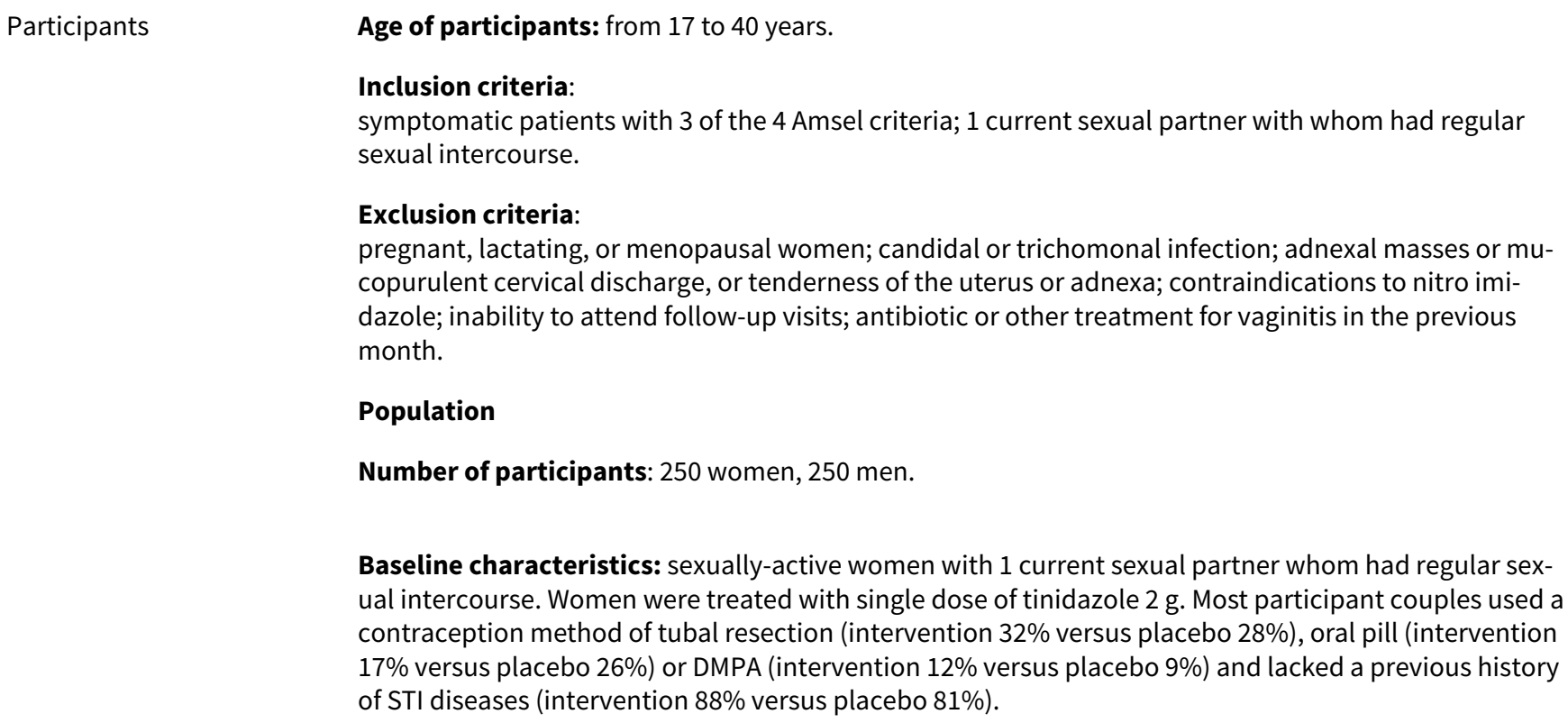

Exclusion criteria:

pregnant, lactating, or menopausal women; candidal or trichomonal infection; adnexal masses or mucopurulent cervical discharge, or tenderness of the uterus or adnexa; contraindications to nitro imidazole; inability to attend follow-up visits; antibiotic or other treatment for vaginitis in the previous month.

\section{Population}

Number of participants: 250 women, 250 men.

Baseline characteristics: sexually-active women with 1 current sexual partner whom had regular sexual intercourse. Women were treated with single dose of tinidazole $2 \mathrm{~g}$. Most participant couples used a contraception method of tubal resection (intervention $32 \%$ versus placebo $28 \%$ ), oral pill (intervention $17 \%$ versus placebo $26 \%$ ) or DMPA (intervention $12 \%$ versus placebo $9 \%$ ) and lacked a previous history of STI diseases (intervention $88 \%$ versus placebo $81 \%$ ).

Interventions

Total number of intervention groups: Two groups.

Intervention: a single oral dose of $2 \mathrm{~g}$ tinidazole.

Comparison: placebo.

The trial included evaluation at 1 and 4 weeks after the start of treatment. The women had a clinical ex-
amination, including the collection of samples of vaginal discharge to check for clue
cells, the determination of vaginal $\mathrm{pH}$ and a
KOH test. At both visits, the participant and her
partner were asked about of any symptoms after taking the medication.
The trial authors defined clinical cure as the proportion of women who remained without at least 2 of
the 4 criteria for BV (Amsell criteria). The trial authors defined symptomatic improvement as partici-
pants with an absence of symptoms of BV (abnormal vaginal discharge or pruritus vulvae, or both). The
participants reported adverse events as symptoms.

\section{Risk of bias}

\begin{tabular}{lll}
\hline Bias & Authors' judgement & Support for judgement \\
\hline $\begin{array}{ll}\text { Random sequence genera- } \\
\text { tion (selection bias) }\end{array}$ & Low risk & $\begin{array}{l}\text { "patients were randomized into two groups using a table of random num- } \\
\text { bers". } \\
\end{array}$ \\
& Comment: this was probably done. \\
\hline
\end{tabular}

Allocation concealment $\quad$ Unclear risk $\quad$ Comment: there was insufficient information to make a judgement.
(selection bias)


Vutyavanich 1993 (Continued)
Blinding of participants
Low risk
"Either $2 \mathrm{~g}$ tinidazole or identical-looking placebo packed similarly in packets and personnel (perfor- of four tablets". Comment: this was probably done.

mance bias)

All outcomes

\begin{tabular}{lll}
\hline $\begin{array}{l}\text { Blinding of outcome as- } \\
\text { sessment (detection bias) } \\
\text { All outcomes }\end{array}$ & Low risk & $\begin{array}{l}\text { "Either } 2 \mathrm{~g} \text { tinidazole or identical-looking placebo packed similarly in packets } \\
\text { of four tablet". Comment: this was probably done. }\end{array}$ \\
\hline $\begin{array}{l}\text { Incomplete outcome data } \\
\text { (attrition bias) } \\
\text { All outcomes }\end{array}$ & Low risk & $\begin{array}{l}20 \% \text { or fewer participants were excluded and also intention to treat analyses } \\
\text { was reported. }\end{array}$ \\
\hline $\begin{array}{l}\text { Selective reporting (re- } \\
\text { porting bias) }\end{array}$ & Unclear risk & The report had insufficient information to permit a judgment of "yes" or "no". \\
\hline $\begin{array}{l}\text { Other bias } \\
\text { Low risk }\end{array}$ & $\begin{array}{l}\text { The study was supported by grant from the Faculty of Medicine Endowment } \\
\text { Fund for Medical Research, Chiang Mai University. Comment: the industry } \\
\text { probably did not influence the results. }\end{array}$
\end{tabular}

Abbreviations: BV: bacterial vaginosis. PAP: Papanicolaou ; IUCD:inrauterine divice, USA: United States of America, DMPA: Depot medroxyprogesterone acetate.

Characteristics of excluded studies [ordered by study ID]

\begin{tabular}{|c|c|}
\hline Study & Reason for exclusion \\
\hline Brenner 1986 & Randomized controlled trial (RCT), but all sexual partners were treated. \\
\hline Bukusi 2011 & RCT, but sexual partners did not received antibiotic treatment. \\
\hline Eschenbach 1983 & RCT, but all sexual partners were treated. \\
\hline Giraldo 2013 & Not a RCT. \\
\hline Hagström 1983 & Not a RCT. \\
\hline Høvik 1983 & RCT, but all sexual partners were treated. \\
\hline Jerve 1984 & Not a RCT. \\
\hline Koumans 2002 & Not a RCT. \\
\hline Larsson 2011 & Not a RCT. \\
\hline Mehta 2012 & Not a RCT. \\
\hline Potter 1999 & Not a RCT. \\
\hline Sharma 2005 & RCT, but all sexual partners were treated. \\
\hline
\end{tabular}

Abbreviations: RCT: randomized controlled trial. 
Characteristics of ongoing studies [ordered by study ID]

\begin{tabular}{ll} 
NCT02209519 & Randomized controlled trial of treatment of male partners of women With BV \\
\hline Mrial name or title & Double-blinded RCT \\
\hline Participants & Male partners of women with recurrent BV \\
\hline Interventions & Metronidazole 500 mg PO twice a day for 7 days versus placebo capsules PO twice a day for 7 days. \\
\hline Outcomes & $\begin{array}{l}\text { Recurrence of BV in the female, recurrence/persistence of BV, number of couples with concordance } \\
\text { of biotypes/strains of Gardnerella vaginalis and time to recurrence. }\end{array}$ \\
\hline Starting date & February 2015 \\
\hline Contact information & Jane R Schwebke, MD; e-mail: schwebke@uab.edu \\
\hline Notes & Study sponsor: University of Alabama at Birmingham
\end{tabular}

Abbreviations: BV: bacterial vaginosis. RCT: randomized controlled trial. PO: per os.

\section{DATA AND ANALYSES}

\section{Comparison 1. Any antibiotic treatment versus placebo}

\begin{tabular}{|c|c|c|c|c|}
\hline Outcome or subgroup title & No. of studies & $\begin{array}{l}\text { No. of partici- } \\
\text { pants }\end{array}$ & Statistical method & Effect size \\
\hline $\begin{array}{l}1 \text { Recurrence of BV between the first and } \\
\text { fourth week }\end{array}$ & 1 & 218 & $\begin{array}{l}\text { Risk Ratio (M-H, Fixed, } \\
95 \% \mathrm{Cl})\end{array}$ & $1.28[0.68,2.43]$ \\
\hline 2 Recurrence of BV after the fourth week & 3 & 372 & $\begin{array}{l}\text { Risk Ratio (M-H, Fixed, } \\
95 \% \mathrm{Cl})\end{array}$ & $1.00[0.67,1.52]$ \\
\hline $\begin{array}{l}3 \text { Clinical improvement during the first } \\
\text { week }\end{array}$ & 4 & 712 & $\begin{array}{l}\text { Risk Ratio }(\mathrm{M}-\mathrm{H}, \text { Fixed, } \\
95 \% \mathrm{Cl})\end{array}$ & $0.99[0.96,1.03]$ \\
\hline $\begin{array}{l}4 \text { Clinical improvement between the first } \\
\text { and fourth week }\end{array}$ & 3 & 590 & $\begin{array}{l}\text { Risk Ratio (M-H, Fixed, } \\
95 \% \mathrm{Cl})\end{array}$ & $1.02[0.94,1.11]$ \\
\hline $\begin{array}{l}5 \text { Clinical improvement after the fourth } \\
\text { week }\end{array}$ & 4 & 572 & $\begin{array}{l}\text { Risk Ratio }(\mathrm{M}-\mathrm{H}, \text { Fixed, } \\
95 \% \mathrm{Cl})\end{array}$ & $0.98[0.90,1.07]$ \\
\hline $\begin{array}{l}6 \text { Symptomatic improvement during the } \\
\text { first week }\end{array}$ & 3 & 577 & $\begin{array}{l}\text { Risk Ratio (M-H, Fixed, } \\
95 \% \mathrm{Cl})\end{array}$ & $1.06[1.00,1.12]$ \\
\hline $\begin{array}{l}7 \text { Symptomatic improvement between } \\
\text { the first and fourth week }\end{array}$ & 2 & 444 & $\begin{array}{l}\text { Risk Ratio (M-H, Fixed, } \\
95 \% \mathrm{Cl})\end{array}$ & $0.93[0.84,1.03]$ \\
\hline $\begin{array}{l}8 \text { Symptomatic improvement after the } \\
\text { fourth week }\end{array}$ & 2 & 296 & $\begin{array}{l}\text { Risk Ratio (M-H, Fixed, } \\
95 \% \mathrm{Cl})\end{array}$ & $1.03[0.90,1.17]$ \\
\hline
\end{tabular}




\begin{tabular}{lllll}
\hline Outcome or subgroup title & No. of studies & $\begin{array}{l}\text { No. of partici- } \\
\text { pants }\end{array}$ & Statistical method & Effect size \\
\hline $\begin{array}{l}\text { 9 Minor adverse events during therapy in } \\
\text { sexual partner }\end{array}$ & 3 & 477 & $\begin{array}{l}\text { Risk Ratio (M-H, Fixed, } \\
95 \% \mathrm{Cl})\end{array}$ & $2.55[1.55,4.18]$ \\
\hline
\end{tabular}

Analysis 1.1. Comparison 1 Any antibiotic treatment versus placebo, Outcome 1 Recurrence of BV between the first and fourth week.

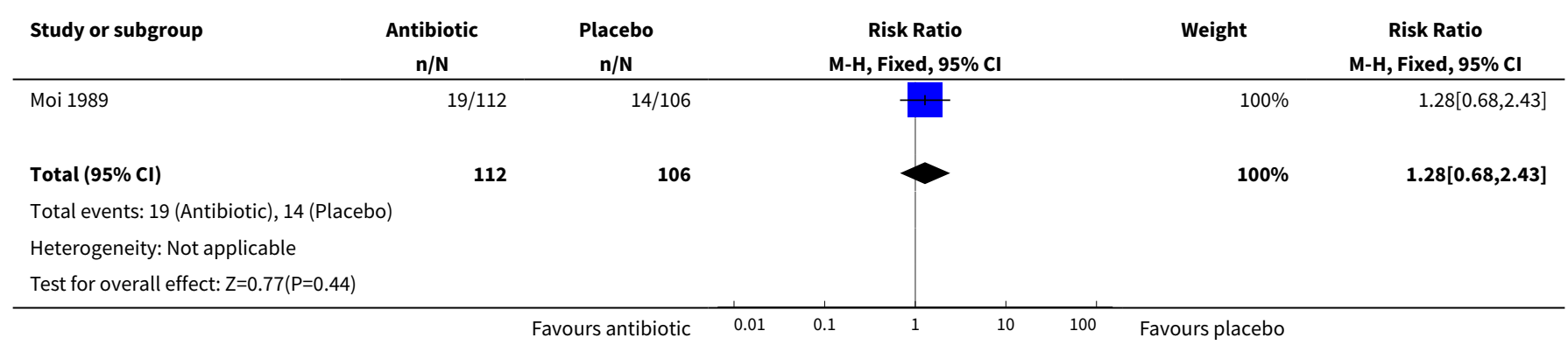

Analysis 1.2. Comparison 1 Any antibiotic treatment versus placebo, Outcome 2 Recurrence of BV after the fourth week.

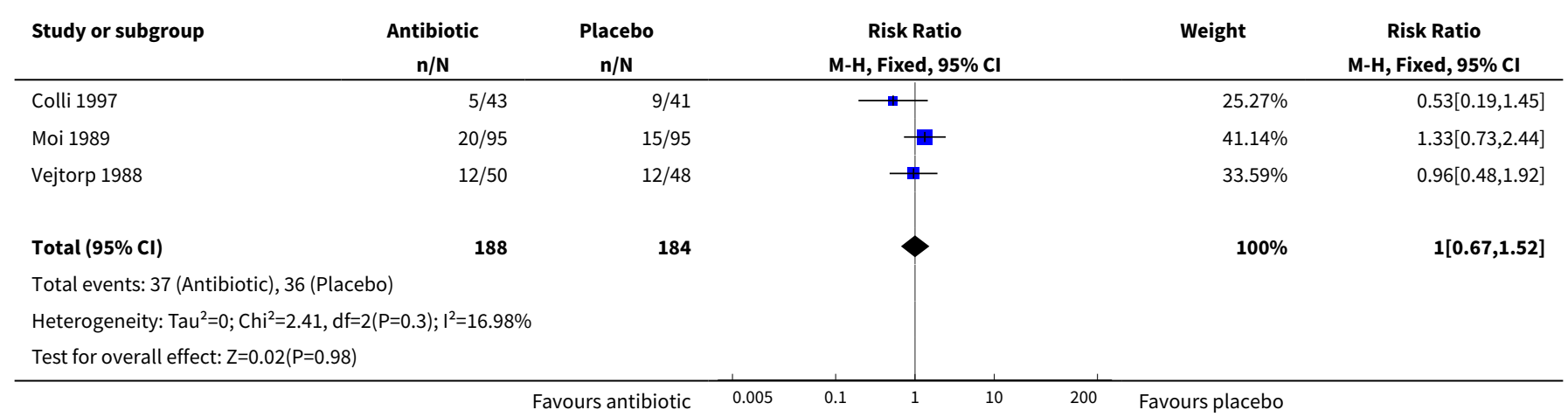

Analysis 1.3. Comparison 1 Any antibiotic treatment versus placebo, Outcome 3 Clinical improvement during the first week.

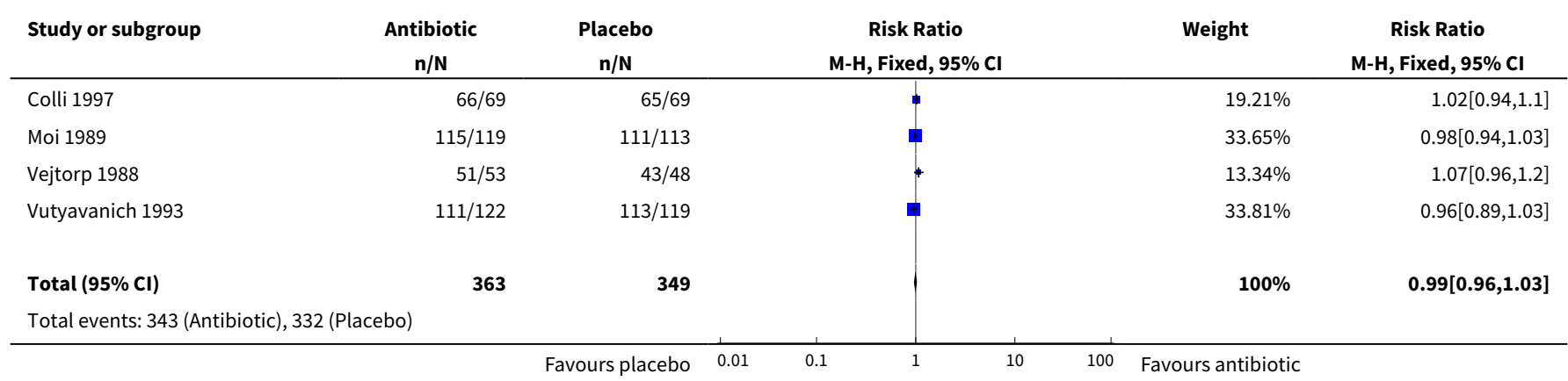




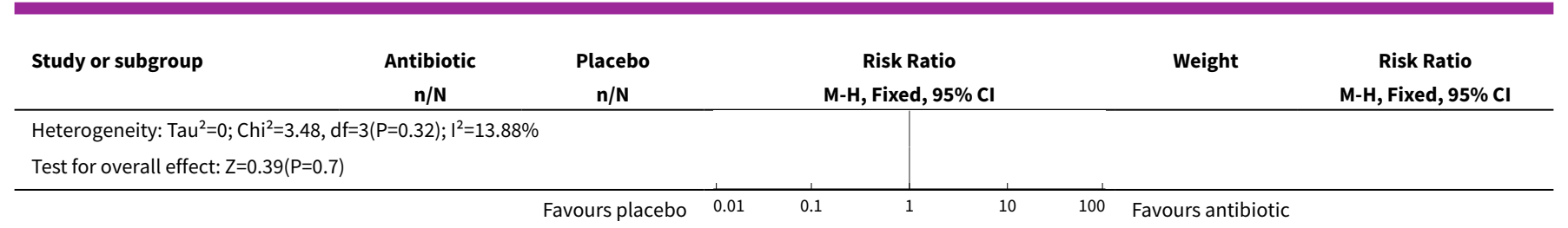

Analysis 1.4. Comparison 1 Any antibiotic treatment versus placebo, Outcome 4 Clinical improvement between the first and fourth week.

\begin{tabular}{|c|c|c|c|c|c|}
\hline Study or subgroup & $\begin{array}{c}\text { Antibiotic } \\
\mathrm{n} / \mathrm{N}\end{array}$ & $\begin{array}{c}\text { Placebo } \\
n / N\end{array}$ & $\begin{array}{c}\text { Risk Ratio } \\
\text { M-H, Fixed, 95\% Cl }\end{array}$ & Weight & $\begin{array}{c}\text { Risk Ratio } \\
\text { M-H, Fixed, 95\% Cl }\end{array}$ \\
\hline Colli 1997 & $60 / 69$ & $62 / 70$ & 申 & $26.79 \%$ & $0.98[0.87,1.11]$ \\
\hline Moi 1989 & $93 / 112$ & $92 / 106$ & 由 & $41.14 \%$ & $0.96[0.86,1.07]$ \\
\hline Vutyavanich 1993 & $83 / 116$ & $74 / 117$ & 贯 & $32.07 \%$ & $1.13[0.95,1.35]$ \\
\hline Total $(95 \% \mathrm{Cl})$ & 297 & 293 & 1 & $100 \%$ & $1.02[0.94,1.11]$ \\
\hline \multicolumn{6}{|c|}{ Total events: 236 (Antibiotic), 228 (Placebo) } \\
\hline \multicolumn{6}{|c|}{ Heterogeneity: $\mathrm{Tau}^{2}=0 ; \mathrm{Chi}^{2}=2.88, \mathrm{df}=2(\mathrm{P}=0.24) ; \mathrm{I}^{2}=30.56 \%$} \\
\hline \multicolumn{6}{|c|}{ Test for overall effect: $Z=0.46(P=0.65)$} \\
\hline
\end{tabular}

Analysis 1.5. Comparison 1 Any antibiotic treatment versus placebo, Outcome 5 Clinical improvement after the fourth week.

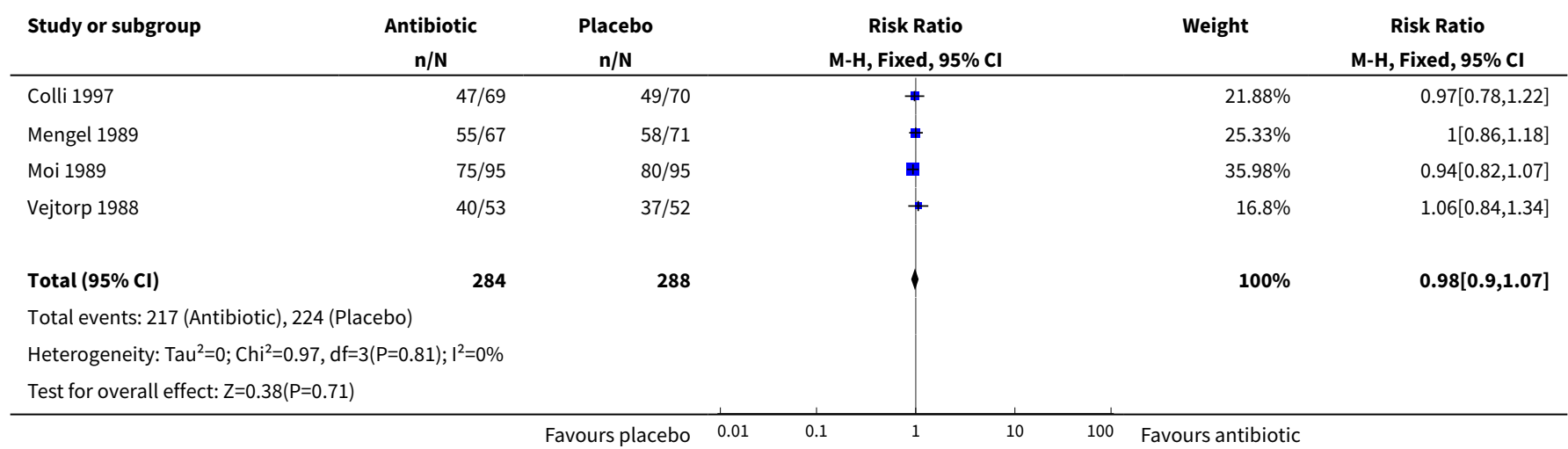

Analysis 1.6. Comparison 1 Any antibiotic treatment versus placebo, Outcome 6 Symptomatic improvement during the first week.

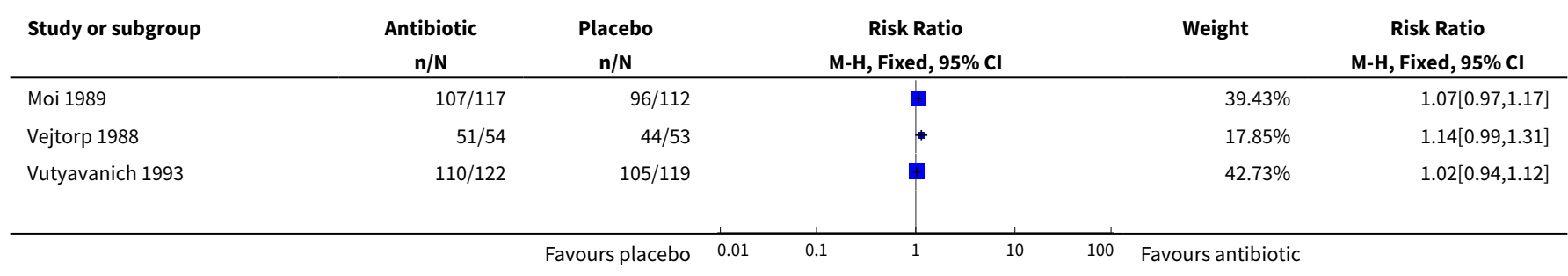




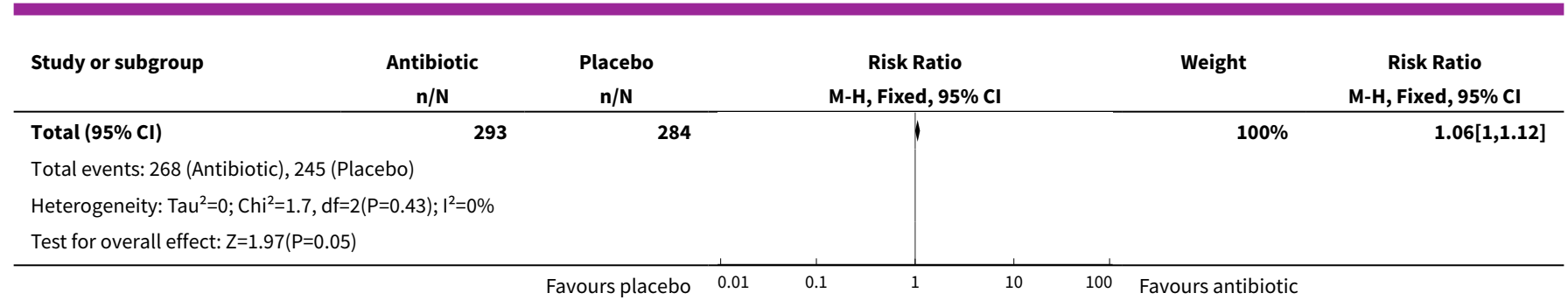

Analysis 1.7. Comparison 1 Any antibiotic treatment versus placebo, Outcome 7 Symptomatic improvement between the first and fourth week.

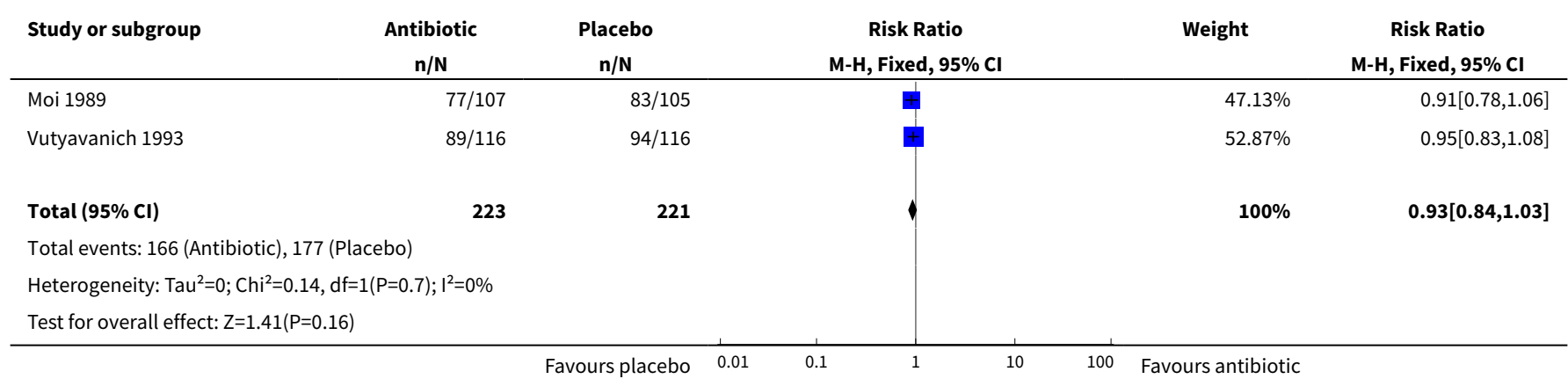

Analysis 1.8. Comparison 1 Any antibiotic treatment versus placebo, Outcome 8 Symptomatic improvement after the fourth week.

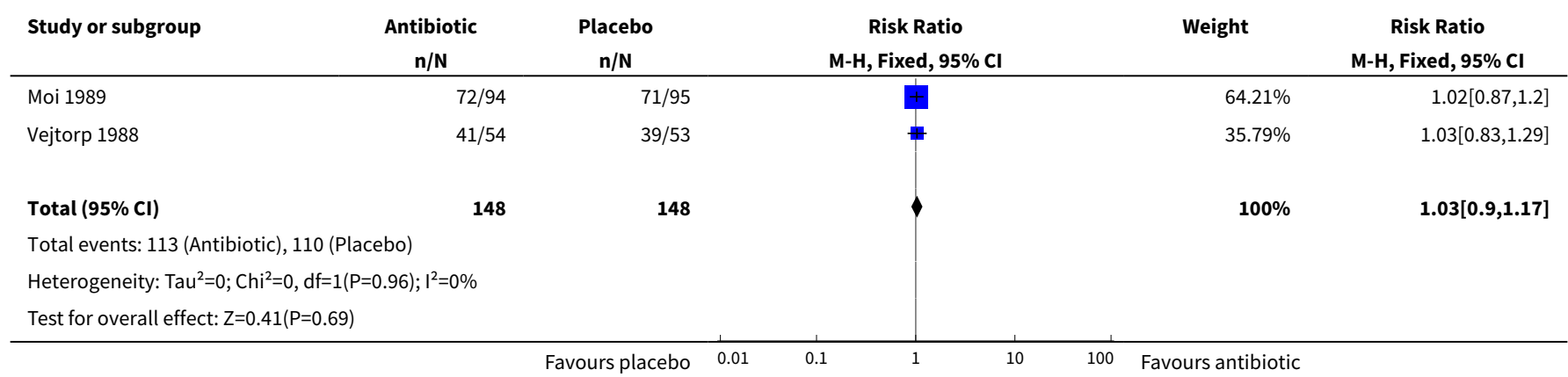

Analysis 1.9. Comparison 1 Any antibiotic treatment versus placebo, Outcome 9 Minor adverse events during therapy in sexual partner.

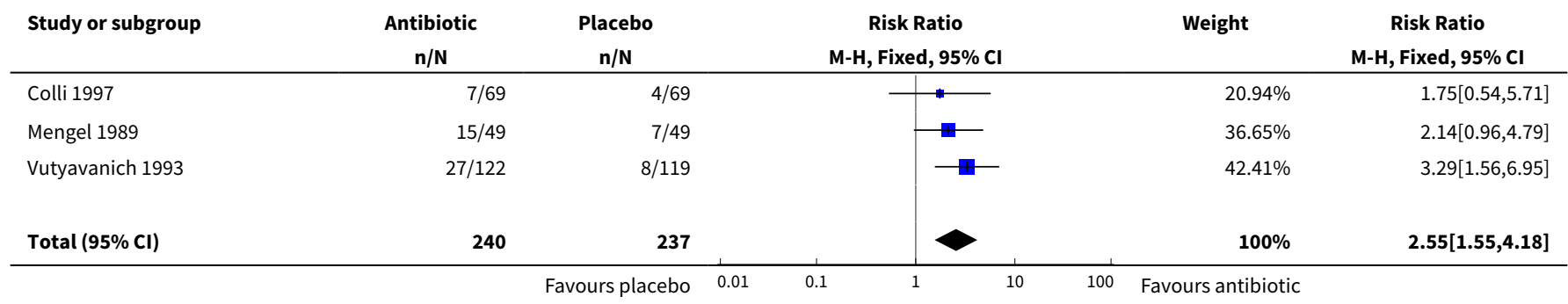




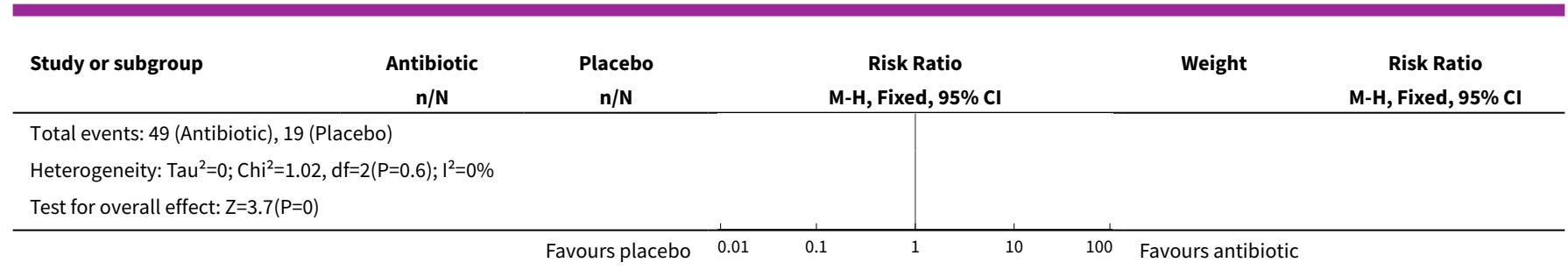

\section{Comparison 2. Any antibiotic treatment versus no intervention}

\begin{tabular}{|c|c|c|c|c|}
\hline Outcome or subgroup title & No. of studies & $\begin{array}{l}\text { No. of partici- } \\
\text { pants }\end{array}$ & Statistical method & Effect size \\
\hline 1 Recurrence of BV after the fourth week & 1 & 51 & $\begin{array}{l}\text { Risk Ratio (M-H, Fixed, } \\
95 \% \mathrm{Cl})\end{array}$ & $1.71[0.65,4.55]$ \\
\hline $\begin{array}{l}2 \text { Clinical improvement between the first } \\
\text { and fourth week }\end{array}$ & 2 & 152 & $\begin{array}{l}\text { Risk Ratio (M-H, Random, } \\
95 \% \mathrm{Cl})\end{array}$ & $0.93[0.70,1.25]$ \\
\hline $\begin{array}{l}3 \text { Symptomatic improvement after the } \\
\text { fourth week }\end{array}$ & 1 & 70 & $\begin{array}{l}\text { Risk Ratio (M-H, Fixed, } \\
95 \% \mathrm{Cl})\end{array}$ & $0.66[0.39,1.11]$ \\
\hline
\end{tabular}

Analysis 2.1. Comparison 2 Any antibiotic treatment versus no intervention, Outcome 1 Recurrence of BV after the fourth week.

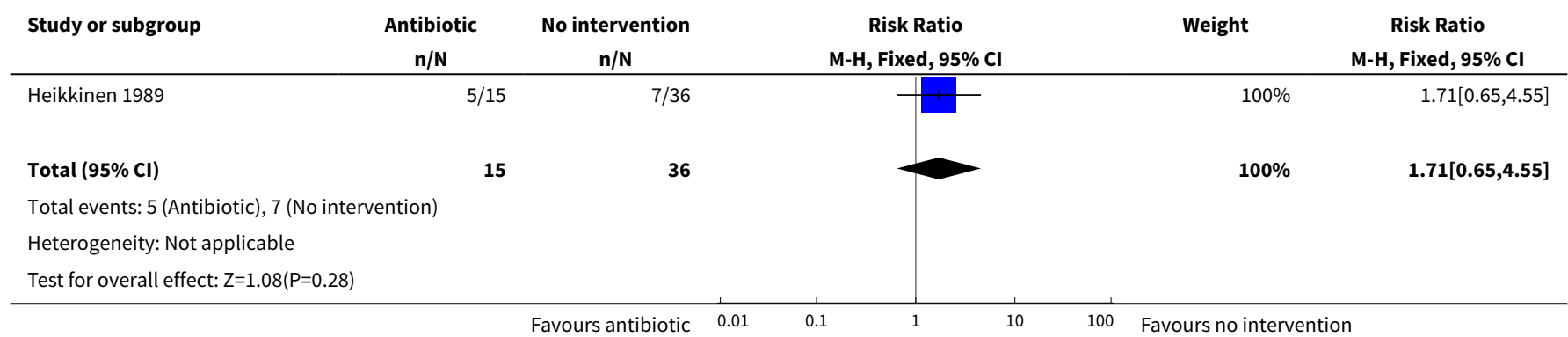

Analysis 2.2. Comparison 2 Any antibiotic treatment versus no intervention, Outcome 2 Clinical improvement between the first and fourth week.

\begin{tabular}{|c|c|c|c|c|c|}
\hline Study or subgroup & $\begin{array}{c}\text { Antibiotic } \\
\mathrm{n} / \mathrm{N} \\
\end{array}$ & $\begin{array}{c}\text { No intervention } \\
\mathrm{n} / \mathrm{N} \\
\end{array}$ & $\begin{array}{c}\text { Risk Ratio } \\
\text { M-H, Random, 95\% Cl }\end{array}$ & Weight & $\begin{array}{c}\text { Risk Ratio } \\
\text { M-H, Random, 95\% Cl } \\
\end{array}$ \\
\hline Heikkinen 1989 & $15 / 24$ & $36 / 46$ & $\rightarrow$ & $36.22 \%$ & $0.8[0.57,1.13]$ \\
\hline Swedberg 1985 & $25 / 27$ & $50 / 55$ & & $63.78 \%$ & $1.02[0.89,1.17]$ \\
\hline Total $(95 \% \mathrm{Cl})$ & 51 & 101 & & $100 \%$ & $0.93[0.7,1.25]$ \\
\hline \multicolumn{6}{|c|}{ Total events: 40 (Antibiotic), 86 (No intervention) } \\
\hline \multicolumn{6}{|c|}{ Test for overall effect: $Z=0.47(P=0.64)$} \\
\hline
\end{tabular}


Analysis 2.3. Comparison 2 Any antibiotic treatment versus no intervention, Outcome 3 Symptomatic improvement after the fourth week.

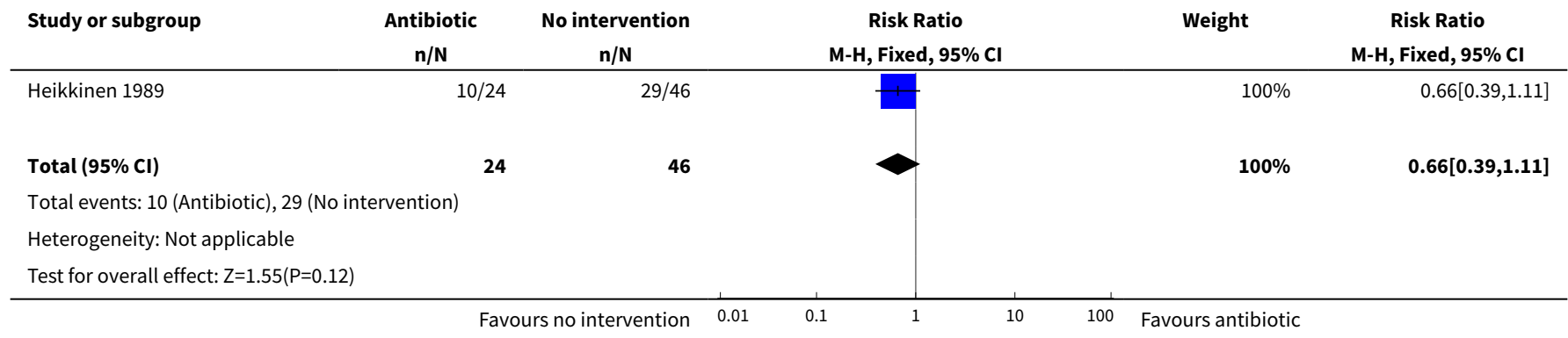

\section{Comparison 3. Any antibiotic treatment versus placebo (by antibiotic type)}

\begin{tabular}{|c|c|c|c|c|}
\hline Outcome or subgroup title & No. of studies & $\begin{array}{l}\text { No. of partici- } \\
\text { pants }\end{array}$ & Statistical method & Effect size \\
\hline $\begin{array}{l}1 \text { Recurrence of BV after the } \\
\text { fourth week }\end{array}$ & 3 & 372 & Risk Ratio (M-H, Fixed, 95\% Cl) & $1.00[0.67,1.52]$ \\
\hline 1.15-Nitroimidazoles & 2 & 288 & Risk Ratio $(\mathrm{M}-\mathrm{H}$, Fixed, $95 \% \mathrm{Cl})$ & $1.17[0.74,1.84]$ \\
\hline 1.2 Lincosamides & 1 & 84 & Risk Ratio (M-H, Fixed, 95\% Cl) & $0.53[0.19,1.45]$ \\
\hline $\begin{array}{l}2 \text { Clinical improvement during } \\
\text { the first week }\end{array}$ & 4 & 712 & Risk Ratio (M-H, Fixed, 95\% Cl) & $0.99[0.96,1.03]$ \\
\hline 2.15-Nitroimidazoles & 3 & 574 & Risk Ratio (M-H, Fixed, 95\% Cl) & $0.99[0.95,1.03]$ \\
\hline 2.2 Lincosamides & 1 & 138 & Risk Ratio (M-H, Fixed, 95\% Cl) & $1.02[0.94,1.10]$ \\
\hline $\begin{array}{l}3 \text { Clinical improvement be- } \\
\text { tween the first and fourth } \\
\text { week }\end{array}$ & 3 & 590 & Risk Ratio (M-H, Fixed, 95\% Cl) & $1.02[0.94,1.11]$ \\
\hline 3.15-Nitroimidazoles & 2 & 451 & Risk Ratio (M-H, Fixed, 95\% Cl) & $1.03[0.93,1.14]$ \\
\hline 3.2 Lincosamides & 1 & 139 & Risk Ratio (M-H, Fixed, 95\% Cl) & $0.98[0.87,1.11]$ \\
\hline $\begin{array}{l}4 \text { Clinical improvement after } \\
\text { the fourth week }\end{array}$ & 4 & 572 & Risk Ratio (M-H, Fixed, 95\% Cl) & $0.98[0.90,1.07]$ \\
\hline 4.15-Nitroimidazoles & 3 & 433 & Risk Ratio (M-H, Fixed, 95\% Cl) & $0.99[0.90,1.08]$ \\
\hline 4.2 Lincosamides & 1 & 139 & Risk Ratio (M-H, Fixed, 95\% Cl) & $0.97[0.78,1.22]$ \\
\hline $\begin{array}{l}5 \text { Minor adverse events during } \\
\text { therapy in sexual partner }\end{array}$ & 3 & 477 & Risk Ratio (M-H, Fixed, 95\% Cl) & $2.55[1.55,4.18]$ \\
\hline 5.15-Nitroimidazoles & 2 & 339 & Risk Ratio (M-H, Fixed, 95\% Cl) & $2.76[1.60,4.77]$ \\
\hline 5.2 Lincosamides & 1 & 138 & Risk Ratio (M-H, Fixed, 95\% Cl) & $1.75[0.54,5.71]$ \\
\hline
\end{tabular}


Analysis 3.1. Comparison 3 Any antibiotic treatment versus placebo (by antibiotic type), Outcome 1 Recurrence of BV after the fourth week.

\begin{tabular}{|c|c|c|c|c|c|}
\hline Study or subgroup & $\begin{array}{c}\text { Antibiotic } \\
n / N\end{array}$ & $\begin{array}{c}\text { Placebo } \\
n / N\end{array}$ & $\begin{array}{c}\text { Risk Ratio } \\
\text { M-H, Fixed, 95\% Cl }\end{array}$ & Weight & $\begin{array}{c}\text { Risk Ratio } \\
\text { M-H, Fixed, 95\% Cl }\end{array}$ \\
\hline \multicolumn{6}{|c|}{ 3.1.1 5-Nitroimidazoles } \\
\hline Moi 1989 & $20 / 95$ & $15 / 95$ & - & $41.14 \%$ & $1.33[0.73,2.44]$ \\
\hline Vejtorp 1988 & $12 / 50$ & $12 / 48$ & & $33.59 \%$ & $0.96[0.48,1.92]$ \\
\hline Subtotal $(95 \% \mathrm{Cl})$ & 145 & 143 & & $74.73 \%$ & $1.17[0.74,1.84]$ \\
\hline \multicolumn{6}{|c|}{ Total events: 32 (Antibiotic), 27 (Placebo) } \\
\hline \multicolumn{6}{|c|}{ Test for overall effect: $Z=0.66(P=0.51)$} \\
\hline \multicolumn{6}{|l|}{ 3.1.2 Lincosamides } \\
\hline Colli 1997 & $5 / 43$ & $9 / 41$ & $\longrightarrow$ & $25.27 \%$ & $0.53[0.19,1.45]$ \\
\hline Subtotal $(95 \% \mathrm{Cl})$ & 43 & 41 & & $25.27 \%$ & $0.53[0.19,1.45]$ \\
\hline \multicolumn{6}{|c|}{ Total events: 5 (Antibiotic), 9 (Placebo) } \\
\hline \multicolumn{6}{|c|}{ Test for overall effect: $Z=1.24(P=0.22)$} \\
\hline Total $(95 \% \mathrm{Cl})$ & 188 & 184 & & $100 \%$ & $1[0.67,1.52]$ \\
\hline \multicolumn{6}{|c|}{ Total events: 37 (Antibiotic), 36 (Placebo) } \\
\hline \multicolumn{6}{|c|}{ Heterogeneity: $\mathrm{Tau}^{2}=0 ; \mathrm{Chi}^{2}=2.41, \mathrm{df}=2(\mathrm{P}=0.3) ; \mathrm{I}^{2}=16.98 \%$} \\
\hline \multicolumn{6}{|c|}{ Test for overall effect: $Z=0.02(P=0.98)$} \\
\hline Test for subgroup dif & , $d f=1(P=0.16)$, & $94 \%$ & & & \\
\hline
\end{tabular}

Analysis 3.2. Comparison 3 Any antibiotic treatment versus placebo (by antibiotic type), Outcome 2 Clinical improvement during the first week.

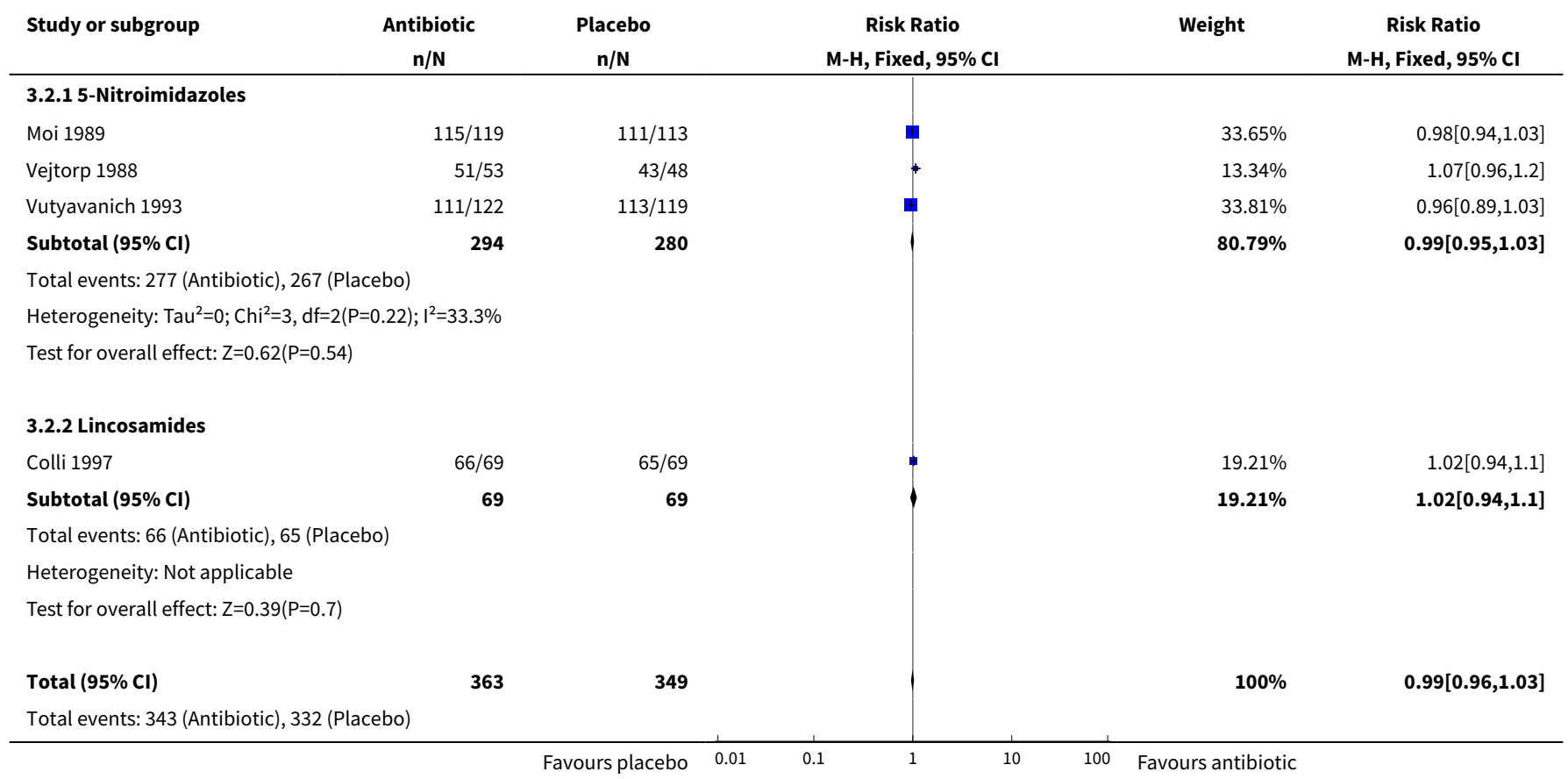




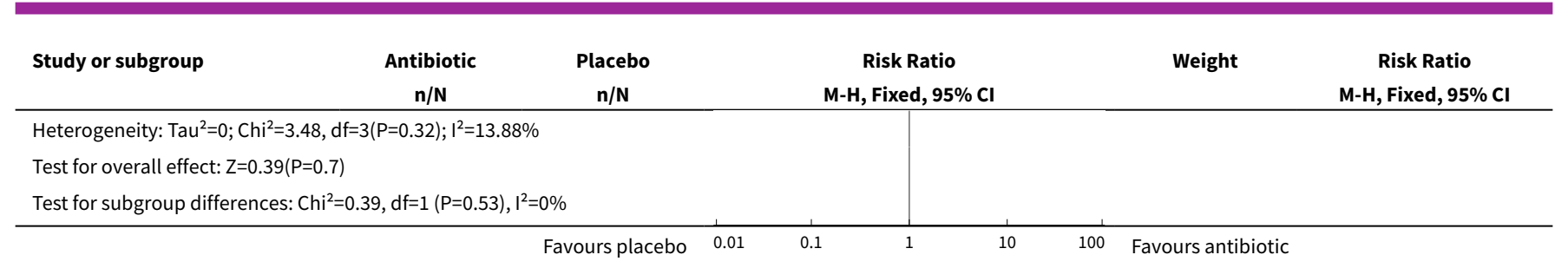

Analysis 3.3. Comparison 3 Any antibiotic treatment versus placebo (by antibiotic type), Outcome 3 Clinical improvement between the first and fourth week.

\begin{tabular}{|c|c|c|c|c|c|}
\hline Study or subgroup & $\begin{array}{c}\text { Antibiotic } \\
\mathrm{n} / \mathrm{N} \\
\end{array}$ & $\begin{array}{c}\text { Placebo } \\
\mathrm{n} / \mathrm{N}\end{array}$ & $\begin{array}{c}\text { Risk Ratio } \\
\text { M-H, Fixed, 95\% Cl }\end{array}$ & Weight & $\begin{array}{c}\text { Risk Ratio } \\
\text { M-H, Fixed, 95\% Cl }\end{array}$ \\
\hline \multicolumn{6}{|c|}{ 3.3.1 5-Nitroimidazoles } \\
\hline Moi 1989 & $93 / 112$ & $92 / 106$ & 由 & $41.14 \%$ & $0.96[0.86,1.07]$ \\
\hline Vutyavanich 1993 & $83 / 116$ & $74 / 117$ & \# & $32.07 \%$ & $1.13[0.95,1.35]$ \\
\hline Subtotal $(95 \% \mathrm{Cl})$ & 228 & 223 & 1 & $73.21 \%$ & $1.03[0.93,1.14]$ \\
\hline \multicolumn{6}{|c|}{ Total events: 176 (Antibiotic), 166 (Placebo) } \\
\hline \multicolumn{6}{|c|}{ Heterogeneity: $\mathrm{Tau}^{2}=0 ; \mathrm{Chi}^{2}=2.79, \mathrm{df}=1(\mathrm{P}=0.09) ; \mathrm{I}^{2}=64.21 \%$} \\
\hline \multicolumn{6}{|c|}{ Test for overall effect: $Z=0.63(P=0.53)$} \\
\hline \multicolumn{6}{|l|}{ 3.3.2 Lincosamides } \\
\hline Colli 1997 & $60 / 69$ & $62 / 70$ & $\phi$ & $26.79 \%$ & $0.98[0.87,1.11]$ \\
\hline Subtotal $(95 \% \mathrm{Cl})$ & 69 & 70 & $\varphi$ & $26.79 \%$ & $0.98[0.87,1.11]$ \\
\hline \multicolumn{6}{|c|}{ Total events: 60 (Antibiotic), 62 (Placebo) } \\
\hline \multicolumn{6}{|c|}{ Test for overall effect: $Z=0.29(P=0.77)$} \\
\hline Total $(95 \% \mathrm{CI})$ & 297 & 293 & 1 & $100 \%$ & $1.02[0.94,1.11]$ \\
\hline \multicolumn{6}{|c|}{ Total events: 236 (Antibiotic), 228 (Placebo) } \\
\hline \multicolumn{6}{|c|}{ Heterogeneity: $\mathrm{Tau}^{2}=0 ; \mathrm{Chi}^{2}=2.88, \mathrm{df}=2(\mathrm{P}=0.24) ; \mathrm{I}^{2}=30.56 \%$} \\
\hline \multicolumn{6}{|c|}{ Test for overall effect: $Z=0.46(P=0.65)$} \\
\hline \multicolumn{6}{|c|}{ Test for subgroup differences: $\mathrm{Chi}^{2}=0.39, \mathrm{df}=1(\mathrm{P}=0.53), \mathrm{I}^{2}=0 \%$} \\
\hline
\end{tabular}

Analysis 3.4. Comparison 3 Any antibiotic treatment versus placebo (by antibiotic type), Outcome 4 Clinical improvement after the fourth week.

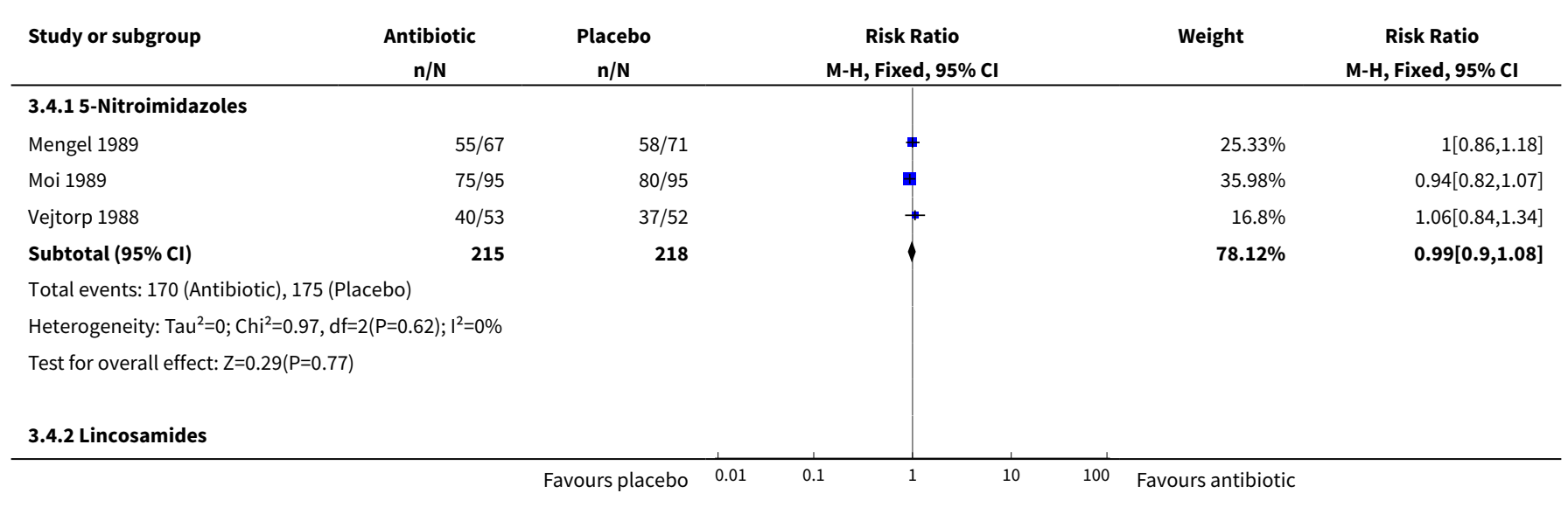




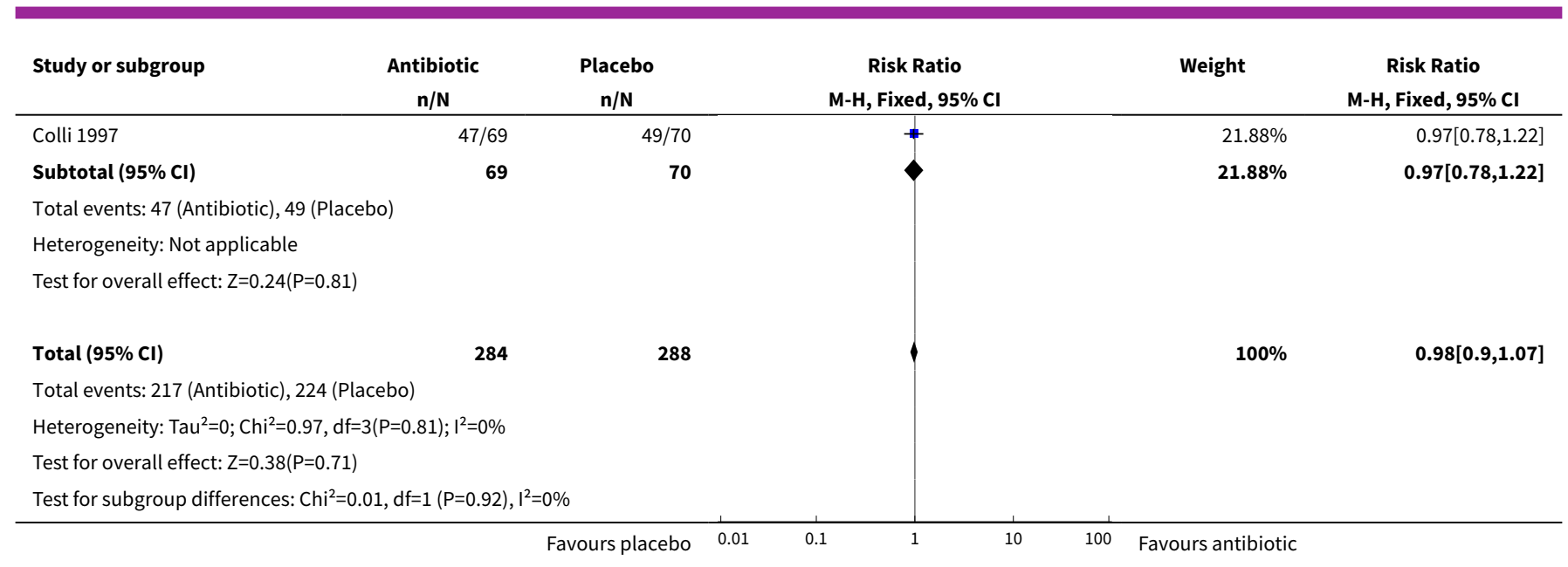

\section{Analysis 3.5. Comparison 3 Any antibiotic treatment versus placebo (by antibiotic} type), Outcome 5 Minor adverse events during therapy in sexual partner.

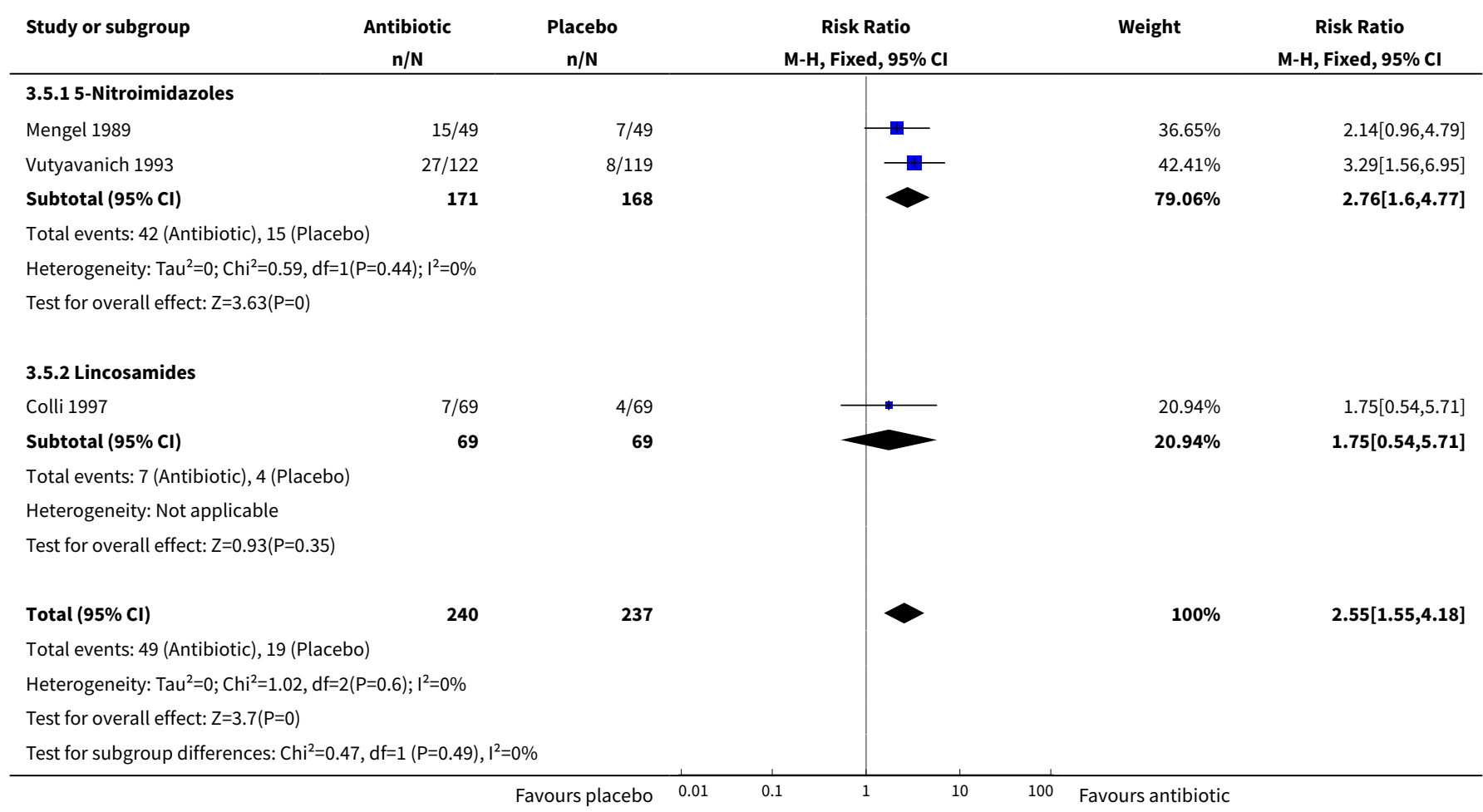

\section{Comparison 4. Any antibiotic treatment versus placebo (by dose)}

\begin{tabular}{lllll}
\hline Outcome or subgroup title & No. of studies & $\begin{array}{l}\text { No. of partici- } \\
\text { pants }\end{array}$ & Statistical method & Effect size \\
\hline $\begin{array}{l}1 \text { Clinical improvement dur- } \\
\text { ing the first week }\end{array}$ & 4 & 712 & Risk Ratio (M-H, Fixed, 95\% Cl) & $0.99[0.96,1.03]$ \\
\hline
\end{tabular}




\begin{tabular}{|c|c|c|c|c|}
\hline Outcome or subgroup title & No. of studies & $\begin{array}{l}\text { No. of partici- } \\
\text { pants }\end{array}$ & Statistical method & Effect size \\
\hline 1.1 Single & 1 & 241 & Risk Ratio (M-H, Fixed, 95\% Cl) & $0.96[0.89,1.03]$ \\
\hline 1.2 Multiple dose & 3 & 471 & Risk Ratio (M-H, Fixed, 95\% Cl) & $1.01[0.97,1.05]$ \\
\hline $\begin{array}{l}2 \text { Clinical improvement be- } \\
\text { tween the first and fourth } \\
\text { week }\end{array}$ & 3 & 590 & Risk Ratio (M-H, Fixed, 95\% Cl) & $1.02[0.94,1.11]$ \\
\hline 2.1 Single & 1 & 233 & Risk Ratio (M-H, Fixed, 95\% Cl) & $1.13[0.95,1.35]$ \\
\hline 2.2 Multiple dose & 2 & 357 & Risk Ratio (M-H, Fixed, 95\% Cl) & $0.97[0.89,1.05]$ \\
\hline $\begin{array}{l}3 \text { Clinical improvement after } \\
\text { the fourth week }\end{array}$ & 4 & 572 & Risk Ratio (M-H, Fixed, 95\% Cl) & $0.98[0.90,1.07]$ \\
\hline 3.1 Single & 1 & 138 & Risk Ratio (M-H, Fixed, 95\% Cl) & $1.00[0.86,1.18]$ \\
\hline 3.2 Multiple dose & 3 & 434 & Risk Ratio (M-H, Fixed, 95\% Cl) & $0.98[0.88,1.09]$ \\
\hline $\begin{array}{l}4 \text { Symptomatic improvement } \\
\text { during the first week }\end{array}$ & 3 & 577 & Risk Ratio (M-H, Fixed, 95\% Cl) & $1.06[1.00,1.12]$ \\
\hline 4.1 Single & 1 & 241 & Risk Ratio (M-H, Fixed, 95\% Cl) & $1.02[0.94,1.12]$ \\
\hline 4.2 Multiple dose & 2 & 336 & Risk Ratio (M-H, Fixed, 95\% Cl) & $1.09[1.01,1.18]$ \\
\hline $\begin{array}{l}5 \text { Symptomatic improvement } \\
\text { between the first and fourth } \\
\text { week }\end{array}$ & 2 & 444 & Risk Ratio (M-H, Fixed, 95\% Cl) & $0.93[0.84,1.03]$ \\
\hline 5.1 Single & 1 & 232 & Risk Ratio (M-H, Fixed, 95\% Cl) & $0.95[0.83,1.08]$ \\
\hline 5.2 Multiple dose & 1 & 212 & Risk Ratio (M-H, Fixed, 95\% Cl) & $0.91[0.78,1.06]$ \\
\hline $\begin{array}{l}6 \text { Minor adverse events dur- } \\
\text { ing therapy in sexual partner }\end{array}$ & 3 & 477 & Risk Ratio (M-H, Fixed, 95\% Cl) & $2.55[1.55,4.18]$ \\
\hline 6.1 Single & 2 & 339 & Risk Ratio (M-H, Fixed, 95\% Cl) & $2.76[1.60,4.77]$ \\
\hline 6.2 Multiple dose & 1 & 138 & Risk Ratio (M-H, Fixed, 95\% Cl) & $1.75[0.54,5.71]$ \\
\hline
\end{tabular}

\section{Analysis 4.1. Comparison 4 Any antibiotic treatment versus placebo (by dose), Outcome 1 Clinical improvement during the first week.}

\begin{tabular}{|c|c|c|c|c|c|}
\hline Study or subgroup & $\begin{array}{c}\text { Antibiotic } \\
n / N\end{array}$ & $\begin{array}{c}\text { Placebo } \\
n / N\end{array}$ & $\begin{array}{c}\text { Risk Ratio } \\
\text { M-H, Fixed, 95\% Cl }\end{array}$ & Weight & $\begin{array}{c}\text { Risk Ratio } \\
\text { M-H, Fixed, } 95 \% \text { CI }\end{array}$ \\
\hline \multicolumn{6}{|l|}{ 4.1.1 Single } \\
\hline Vutyavanich 1993 & $111 / 122$ & $113 / 119$ & 由 & $33.81 \%$ & $0.96[0.89,1.03]$ \\
\hline Subtotal $(95 \% \mathrm{Cl})$ & 122 & 119 & 1 & $33.81 \%$ & $0.96[0.89,1.03]$ \\
\hline \multicolumn{6}{|c|}{ Total events: 111 (Antibiotic), 113 (Placebo) } \\
\hline
\end{tabular}




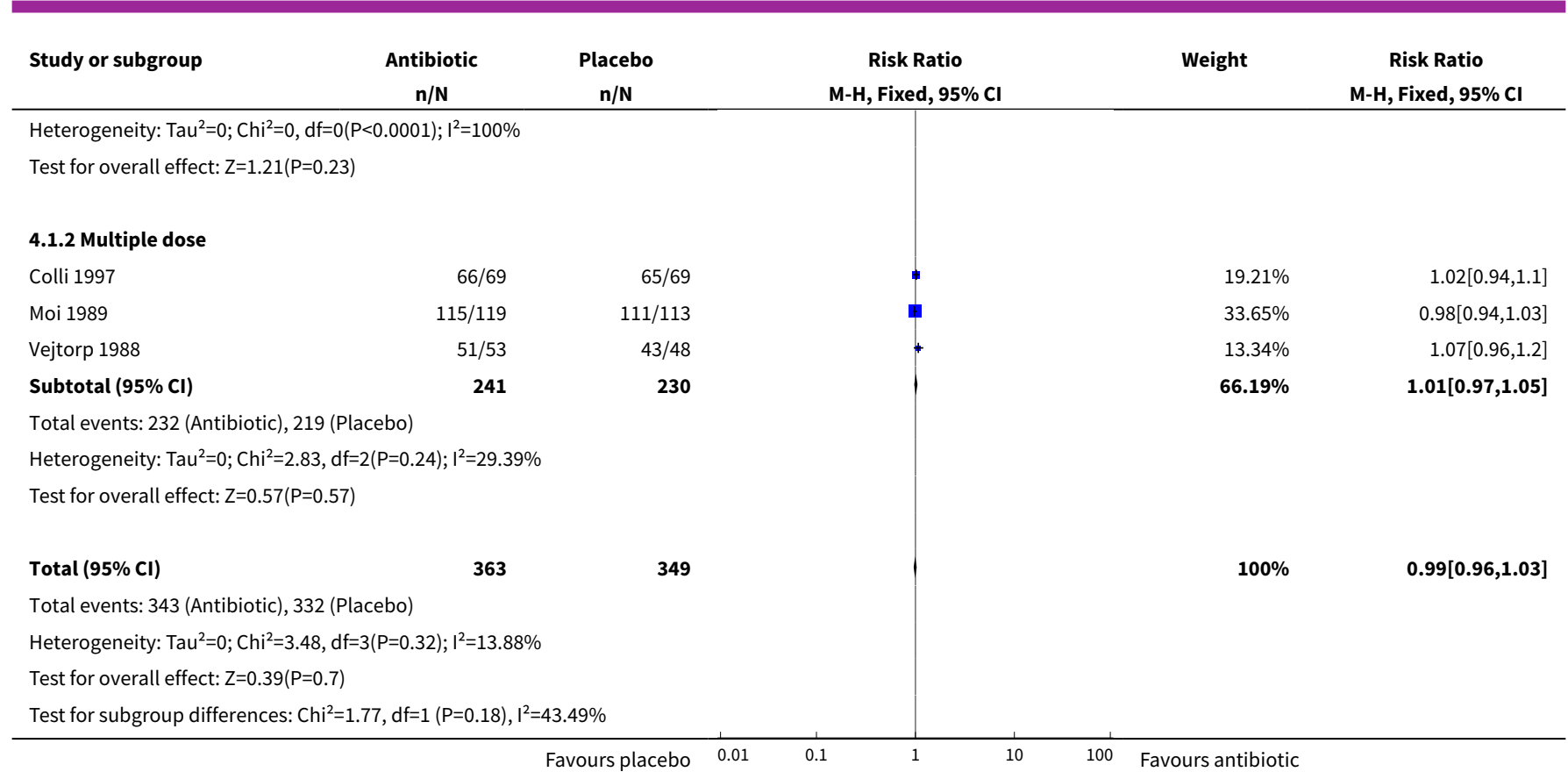

Analysis 4.2. Comparison 4 Any antibiotic treatment versus placebo (by dose), Outcome 2 Clinical improvement between the first and fourth week.

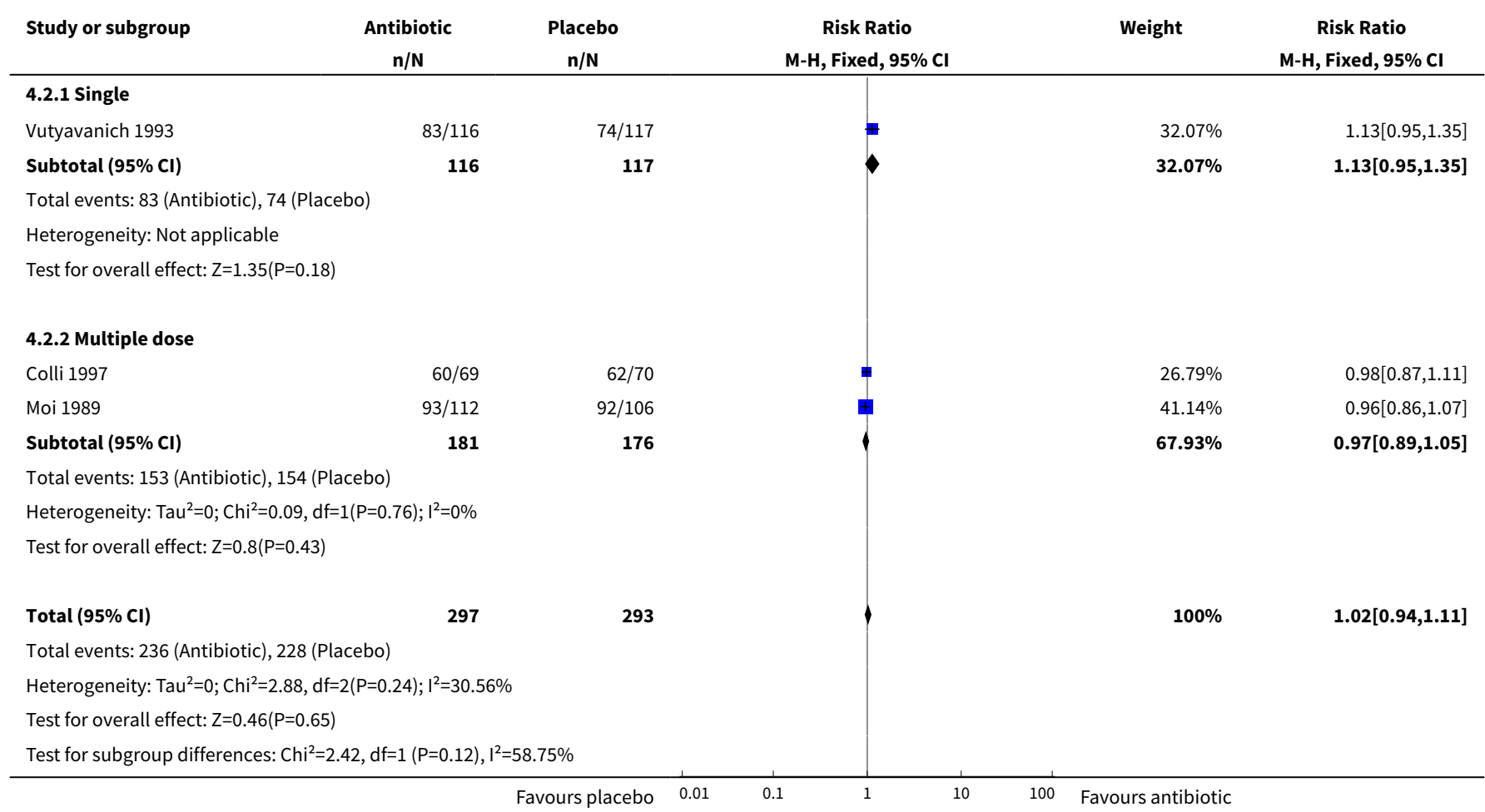


Analysis 4.3. Comparison 4 Any antibiotic treatment versus placebo (by dose), Outcome 3 Clinical improvement after the fourth week.

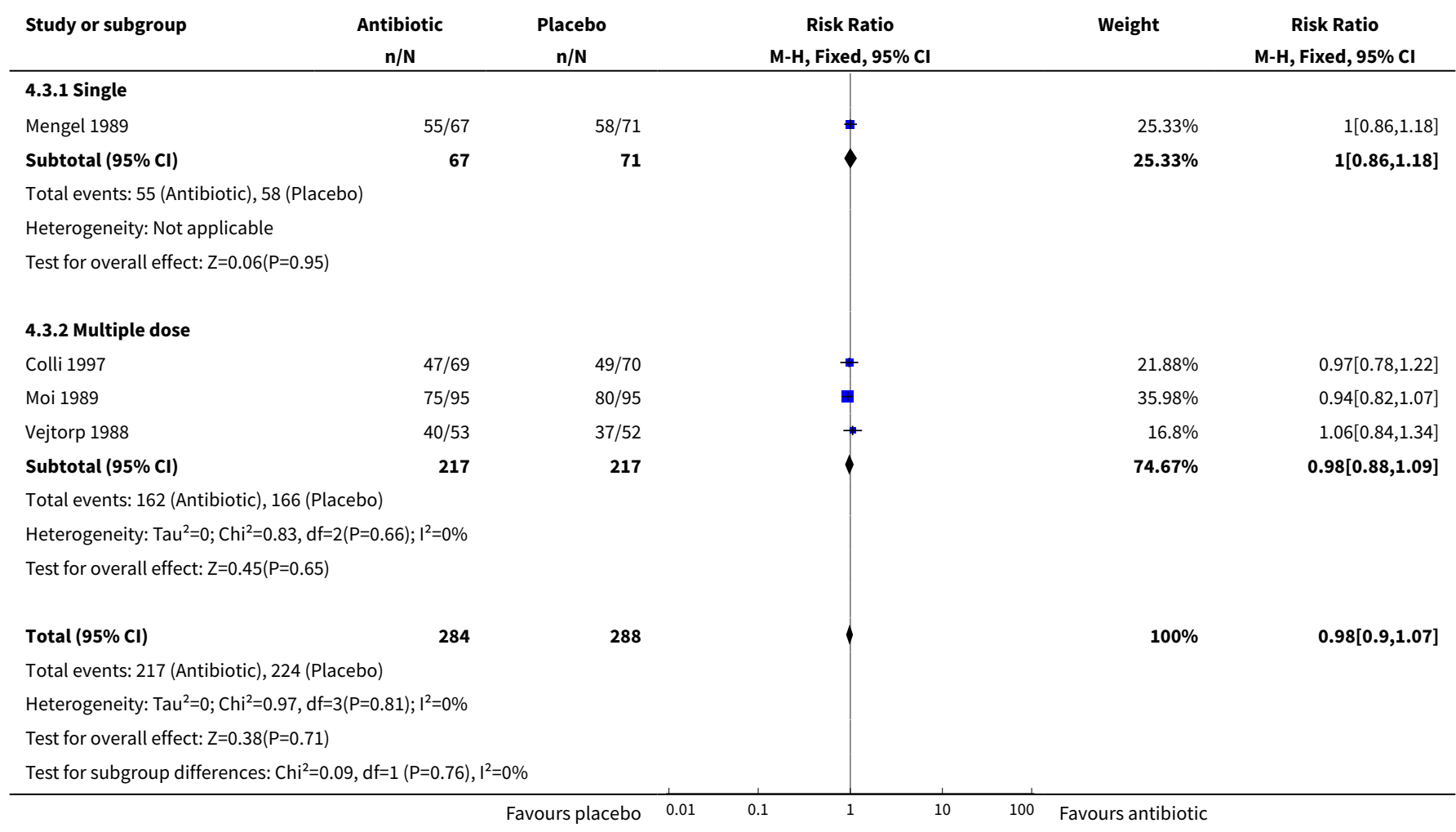

Analysis 4.4. Comparison 4 Any antibiotic treatment versus placebo (by dose), Outcome 4 Symptomatic improvement during the first week.

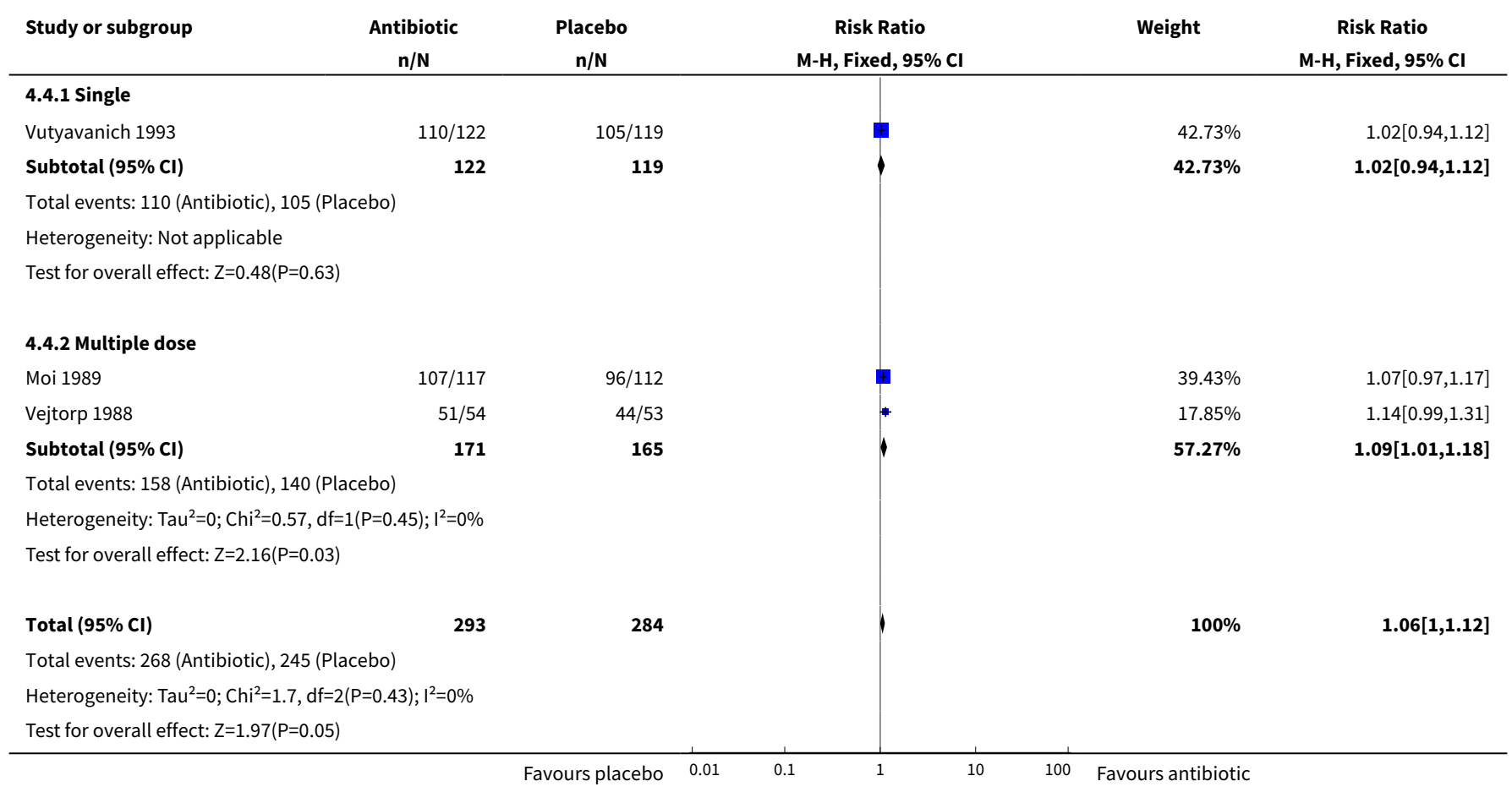




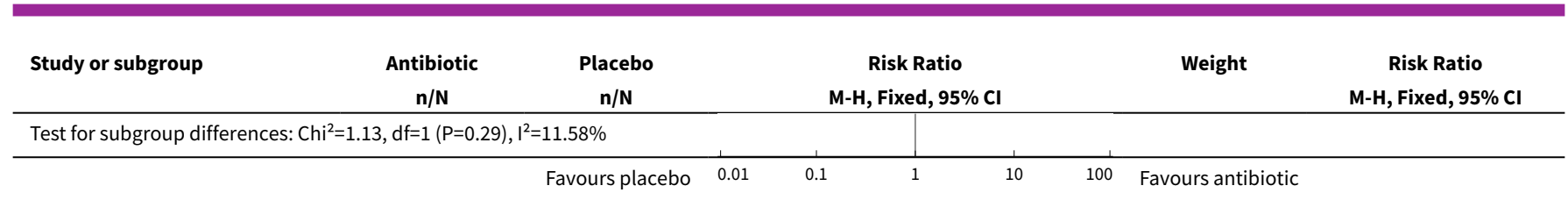

Analysis 4.5. Comparison 4 Any antibiotic treatment versus placebo (by dose), Outcome 5 Symptomatic improvement between the first and fourth week.

\begin{tabular}{|c|c|c|c|c|c|}
\hline Study or subgroup & $\begin{array}{c}\text { Antibiotic } \\
\mathrm{n} / \mathrm{N}\end{array}$ & $\begin{array}{l}\text { Placebo } \\
\mathrm{n} / \mathrm{N}\end{array}$ & $\begin{array}{c}\text { Risk Ratio } \\
\text { M-H, Fixed, } 95 \% \mathrm{CI}\end{array}$ & Weight & $\begin{array}{c}\text { Risk Ratio } \\
\text { M-H, Fixed, } 95 \% \mathrm{Cl}\end{array}$ \\
\hline \multicolumn{6}{|l|}{ 4.5.1 Single } \\
\hline Vutyavanich 1993 & $89 / 116$ & $94 / 116$ & 由 & $52.87 \%$ & $0.95[0.83,1.08]$ \\
\hline Subtotal $(95 \% \mathrm{Cl})$ & 116 & 116 & 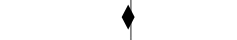 & $52.87 \%$ & $0.95[0.83,1.08]$ \\
\hline \multicolumn{6}{|c|}{ Total events: 89 (Antibiotic), 94 (Placebo) } \\
\hline \multicolumn{6}{|c|}{ Heterogeneity: Not applicable } \\
\hline \multicolumn{6}{|c|}{ Test for overall effect: $\mathrm{Z}=0.8(\mathrm{P}=0.42)$} \\
\hline \multicolumn{6}{|l|}{ 4.5.2 Multiple dose } \\
\hline Moi 1989 & $77 / 107$ & $83 / 105$ & H & $47.13 \%$ & $0.91[0.78,1.06]$ \\
\hline Subtotal $(95 \% \mathrm{Cl})$ & 107 & 105 & $\bullet$ & $47.13 \%$ & $0.91[0.78,1.06]$ \\
\hline \multicolumn{6}{|c|}{ Total events: 77 (Antibiotic), 83 (Placebo) } \\
\hline \multicolumn{6}{|c|}{ Heterogeneity: Not applicable } \\
\hline \multicolumn{6}{|c|}{ Test for overall effect: $Z=1.2(P=0.23)$} \\
\hline Total $(95 \% \mathrm{Cl})$ & 223 & 221 & 1 & $100 \%$ & $0.93[0.84,1.03]$ \\
\hline \multicolumn{6}{|c|}{ Total events: 166 (Antibiotic), 177 (Placebo) } \\
\hline \multicolumn{6}{|c|}{ Heterogeneity: $\mathrm{Tau}^{2}=0 ; \mathrm{Chi}^{2}=0.14, \mathrm{df}=1(\mathrm{P}=0.7) ; 1^{2}=0 \%$} \\
\hline \multicolumn{6}{|c|}{ Test for overall effect: $Z=1.41(P=0.16)$} \\
\hline \multicolumn{6}{|c|}{ Test for subgroup differences: $\mathrm{Chi}^{2}=0.14, \mathrm{df}=1(\mathrm{P}=0.71), \mathrm{I}^{2}=0 \%$} \\
\hline
\end{tabular}

Analysis 4.6. Comparison 4 Any antibiotic treatment versus placebo (by dose), Outcome 6 Minor adverse events during therapy in sexual partner.

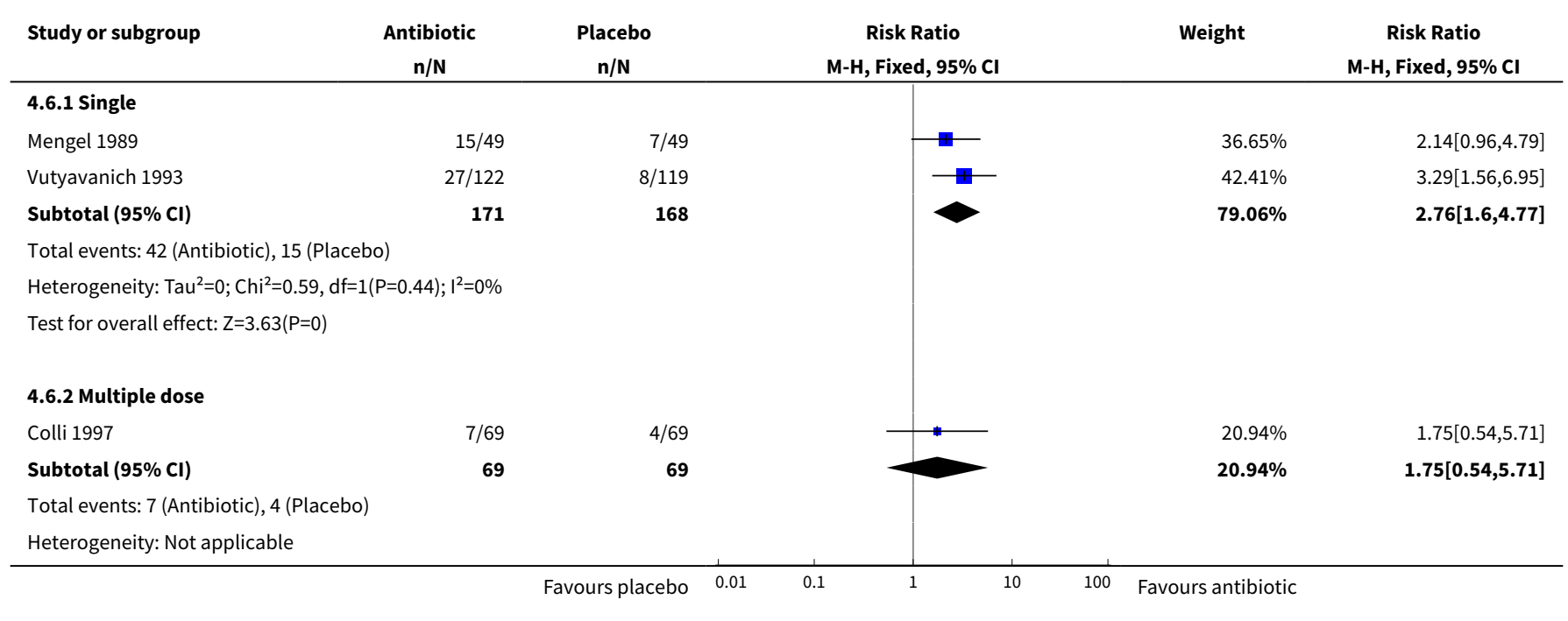




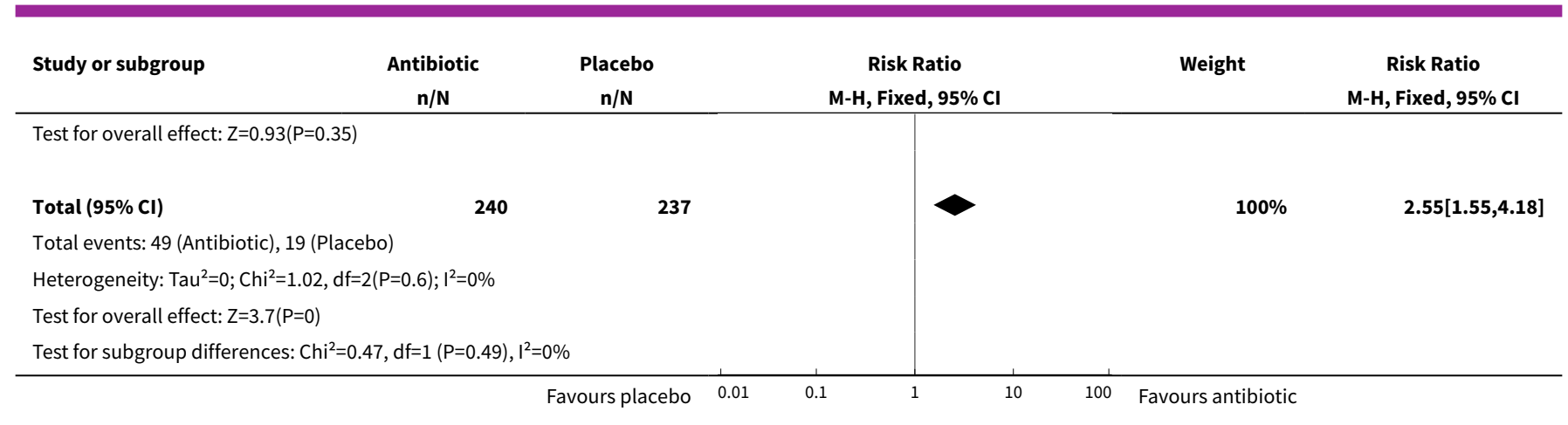

\section{Comparison 5. Any antibiotic treatment versus placebo (attrition bias)}

\begin{tabular}{|c|c|c|c|c|}
\hline Outcome or subgroup title & No. of studies & $\begin{array}{l}\text { No. of partici- } \\
\text { pants }\end{array}$ & Statistical method & Effect size \\
\hline $\begin{array}{l}1 \text { Recurrence of BV after the } \\
\text { fourth week }\end{array}$ & 3 & 372 & Risk Ratio (M-H, Fixed, 95\% Cl) & $1.00[0.67,1.52]$ \\
\hline 1.1 Low risk & 1 & 98 & Risk Ratio (M-H, Fixed, 95\% Cl) & $0.96[0.48,1.92]$ \\
\hline 1.2 Unclear risk & 2 & 274 & Risk Ratio (M-H, Fixed, 95\% Cl) & $1.03[0.62,1.71]$ \\
\hline $\begin{array}{l}2 \text { Clinical improvement dur- } \\
\text { ing the first week }\end{array}$ & 4 & 712 & Risk Ratio (M-H, Fixed, 95\% Cl) & $0.99[0.96,1.03]$ \\
\hline 2.1 Low risk & 2 & 342 & Risk Ratio (M-H, Fixed, 95\% Cl) & $0.99[0.93,1.05]$ \\
\hline 2.2 Unclear risk & 2 & 370 & Risk Ratio (M-H, Fixed, 95\% Cl) & $1.00[0.96,1.03]$ \\
\hline $\begin{array}{l}3 \text { Clinical improvement be- } \\
\text { tween the first and fourth } \\
\text { week }\end{array}$ & 3 & 590 & Risk Ratio (M-H, Fixed, 95\% Cl) & $1.02[0.94,1.11]$ \\
\hline 3.1 Low risk & 1 & 233 & Risk Ratio (M-H, Fixed, 95\% Cl) & $1.13[0.95,1.35]$ \\
\hline 3.2 Unclear risk & 2 & 357 & Risk Ratio (M-H, Fixed, 95\% Cl) & $0.97[0.89,1.05]$ \\
\hline $\begin{array}{l}4 \text { Clinical improvement after } \\
\text { the fourth week }\end{array}$ & 4 & 572 & Risk Ratio (M-H, Fixed, 95\% Cl) & $0.98[0.90,1.07]$ \\
\hline 4.1 Low risk & 2 & 243 & Risk Ratio (M-H, Fixed, 95\% Cl) & $1.03[0.90,1.17]$ \\
\hline 4.2 Unclear risk & 2 & 329 & Risk Ratio (M-H, Fixed, 95\% Cl) & $0.95[0.84,1.07]$ \\
\hline $\begin{array}{l}5 \text { Symptomatic improvement } \\
\text { during the first week }\end{array}$ & 3 & 577 & Risk Ratio (M-H, Fixed, 95\% Cl) & $1.06[1.00,1.12]$ \\
\hline 5.1 Low risk & 2 & 348 & Risk Ratio (M-H, Fixed, 95\% Cl) & $1.06[0.98,1.14]$ \\
\hline 5.2 Unclear risk & 1 & 229 & Risk Ratio (M-H, Fixed, 95\% Cl) & $1.07[0.97,1.17]$ \\
\hline
\end{tabular}




\begin{tabular}{lllll}
\hline Outcome or subgroup title & No. of studies & $\begin{array}{l}\text { No. of partici- } \\
\text { pants }\end{array}$ & Statistical method & Effect size \\
\hline $\begin{array}{l}\text { 6 Symptomatic improvement } \\
\text { between the first and fourth } \\
\text { week }\end{array}$ & 2 & 444 & Risk Ratio (M-H, Fixed, 95\% Cl) & $0.93[0.84,1.03]$ \\
\hline $\begin{array}{l}6.1 \text { Low risk } \\
\text { 6.2 Unclear risk }\end{array}$ & 1 & 232 & Risk Ratio (M-H, Fixed, 95\% Cl) & $0.95[0.83,1.08]$ \\
\hline $\begin{array}{l}7 \text { Symptomatic improvement } \\
\text { after the fourth week }\end{array}$ & 2 & 212 & Risk Ratio (M-H, Fixed, 95\% Cl) & $0.91[0.78,1.06]$ \\
\hline $\begin{array}{l}7.1 \text { Low risk } \\
7.2 \text { Unclear risk }\end{array}$ & 1 & 296 & Risk Ratio (M-H, Fixed, 95\% Cl) & $1.03[0.90,1.17]$ \\
\hline $\begin{array}{l}8 \text { Minor adverse events dur- } \\
\text { ing therapy in sexual partner }\end{array}$ & 3 & 107 & Risk Ratio (M-H, Fixed, 95\% Cl) & $1.03[0.83,1.29]$ \\
\hline $\begin{array}{l}8.1 \text { Low risk } \\
8.2 \text { Unclear risk }\end{array}$ & 2 & 189 & Risk Ratio (M-H, Fixed, 95\% Cl) & $1.02[0.87,1.20]$ \\
\hline
\end{tabular}

Analysis 5.1. Comparison 5 Any antibiotic treatment versus placebo (attrition bias), Outcome 1 Recurrence of BV after the fourth week.

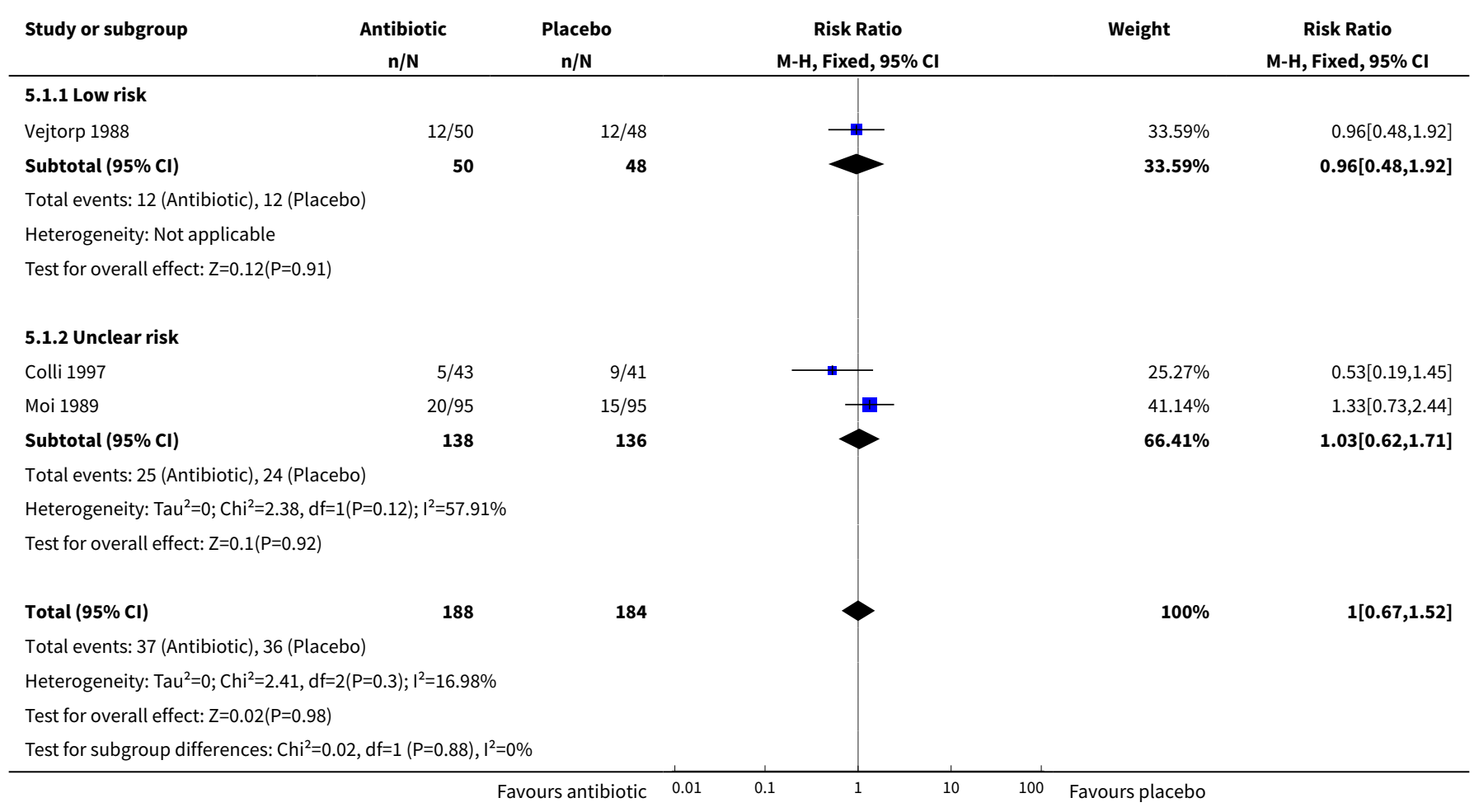


Analysis 5.2. Comparison 5 Any antibiotic treatment versus placebo

(attrition bias), Outcome 2 Clinical improvement during the first week.

\begin{tabular}{|c|c|c|c|c|c|}
\hline Study or subgroup & $\begin{array}{c}\text { Antibiotic } \\
\mathrm{n} / \mathrm{N}\end{array}$ & $\begin{array}{c}\text { Placebo } \\
n / N\end{array}$ & $\begin{array}{c}\text { Risk Ratio } \\
\text { M-H, Fixed, 95\% Cl }\end{array}$ & Weight & $\begin{array}{c}\text { Risk Ratio } \\
\text { M-H, Fixed, } 95 \% \mathrm{Cl}\end{array}$ \\
\hline \multicolumn{6}{|l|}{ 5.2.1 Low risk } \\
\hline Vejtorp 1988 & $51 / 53$ & $43 / 48$ & * & $13.34 \%$ & $1.07[0.96,1.2]$ \\
\hline Vutyavanich 1993 & $111 / 122$ & $113 / 119$ & $\mathbf{m}$ & $33.81 \%$ & $0.96[0.89,1.03]$ \\
\hline Subtotal $(95 \% \mathrm{Cl})$ & 175 & 167 & 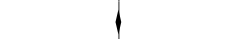 & $47.14 \%$ & $0.99[0.93,1.05]$ \\
\hline \multicolumn{6}{|c|}{ Total events: 162 (Antibiotic), 156 (Placebo) } \\
\hline \multicolumn{6}{|c|}{ Test for overall effect: $Z=0.3(P=0.76)$} \\
\hline \multicolumn{6}{|l|}{ 5.2.2 Unclear risk } \\
\hline Colli 1997 & $66 / 69$ & $65 / 69$ & 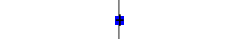 & $19.21 \%$ & $1.02[0.94,1.1]$ \\
\hline Moi 1989 & $115 / 119$ & $111 / 113$ & 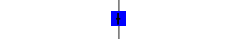 & $33.65 \%$ & $0.98[0.94,1.03]$ \\
\hline Subtotal $(95 \% \mathrm{Cl})$ & 188 & 182 & 1 & $52.86 \%$ & $1[0.96,1.03]$ \\
\hline \multicolumn{6}{|c|}{ Heterogeneity: $\operatorname{Tau}^{2}=0 ; \mathrm{Chi}^{2}=0.56, \mathrm{df}=1(\mathrm{P}=0.46) ;\left.\right|^{2}=0 \%$} \\
\hline \multicolumn{6}{|c|}{ Test for overall effect: $Z=0.24(P=0.81)$} \\
\hline Total $(95 \% \mathrm{Cl})$ & 363 & 349 & & $100 \%$ & $0.99[0.96,1.03]$ \\
\hline \multicolumn{6}{|c|}{ Total events: 343 (Antibiotic), 332 (Placebo) } \\
\hline \multicolumn{6}{|c|}{ Heterogeneity: $\mathrm{Tau}^{2}=0 ; \mathrm{Chi}^{2}=3.48, \mathrm{df}=3(\mathrm{P}=0.32) ; \mathrm{I}^{2}=13.88 \%$} \\
\hline \multicolumn{6}{|c|}{ Test for overall effect: $Z=0.39(P=0.7)$} \\
\hline Test for subgroup dif & $1, \mathrm{df}=1(\mathrm{P}=0.9), \mathrm{I}^{2}$ & & & & \\
\hline
\end{tabular}

Analysis 5.3. Comparison 5 Any antibiotic treatment versus placebo (attrition bias), Outcome 3 Clinical improvement between the first and fourth week.

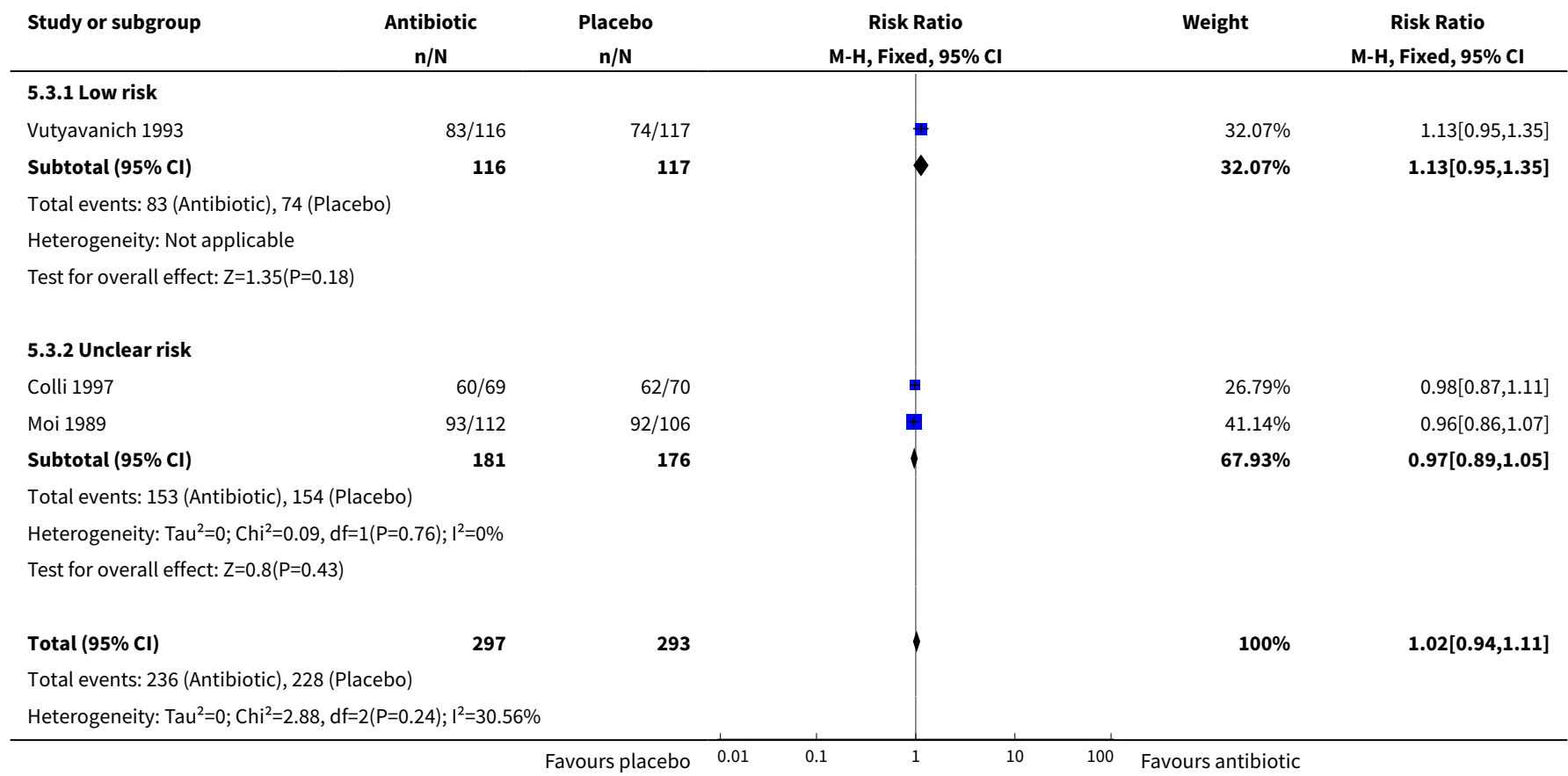




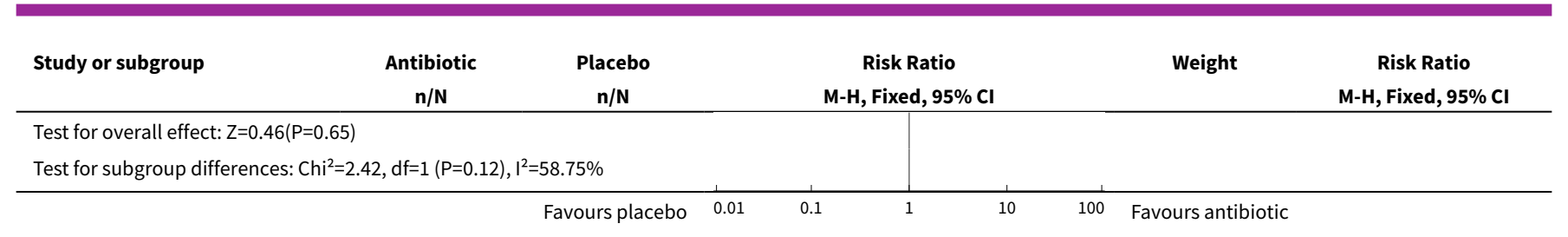

Analysis 5.4. Comparison 5 Any antibiotic treatment versus placebo (attrition bias), Outcome 4 Clinical improvement after the fourth week.

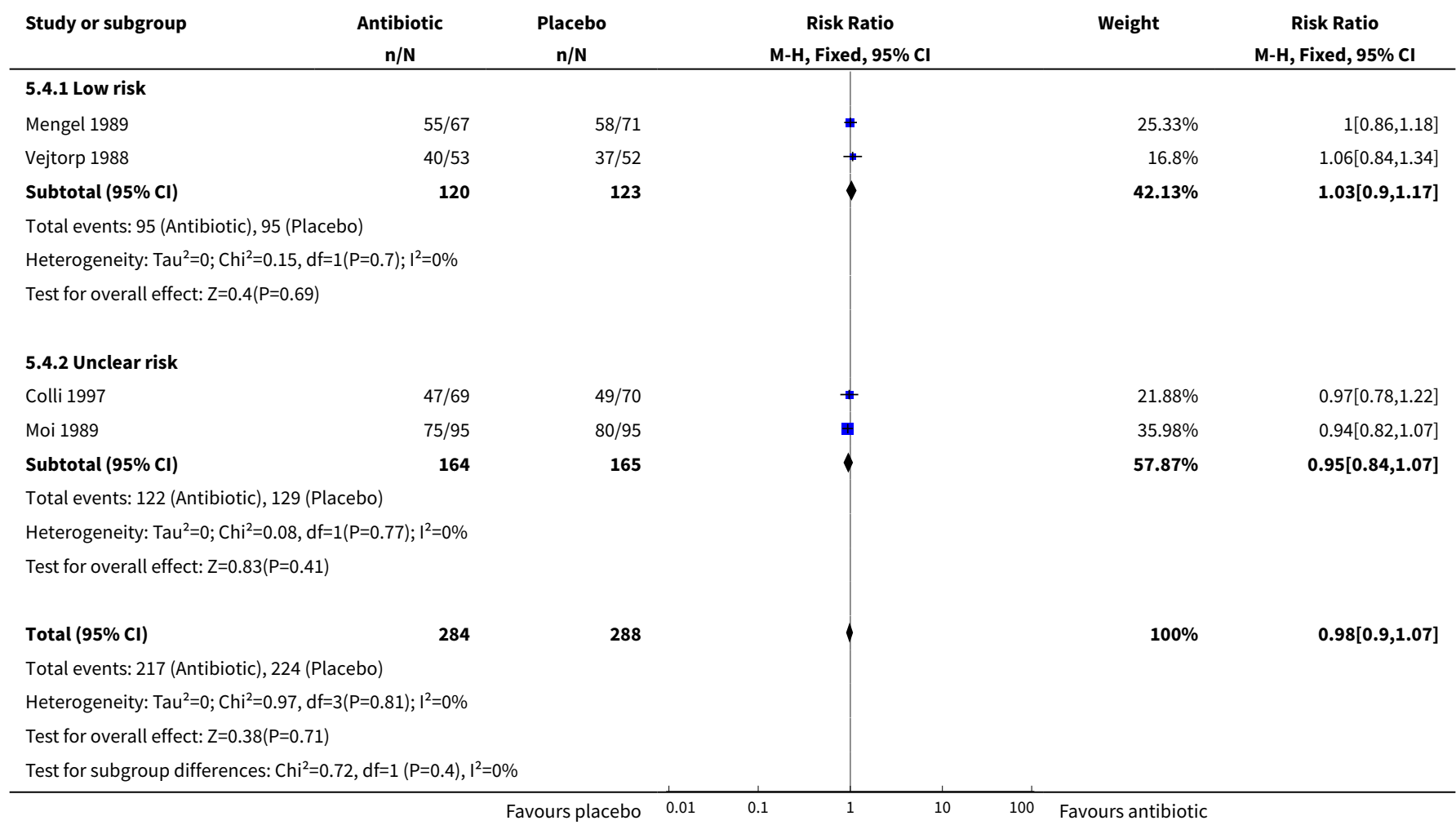

Analysis 5.5. Comparison 5 Any antibiotic treatment versus placebo (attrition bias), Outcome 5 Symptomatic improvement during the first week.

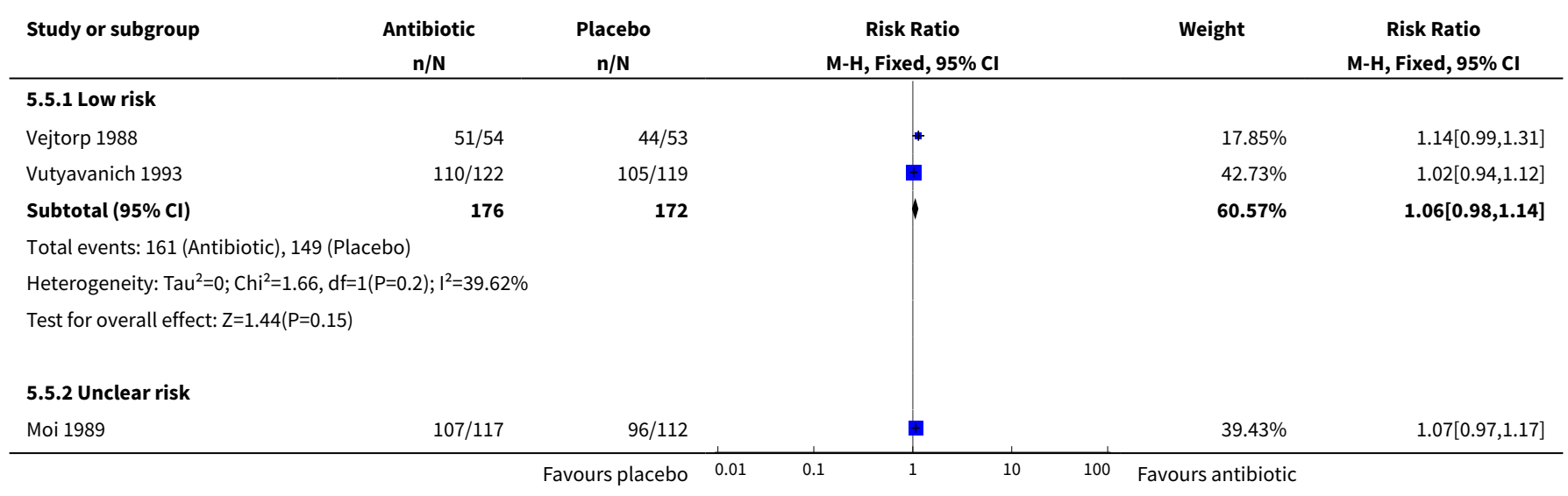




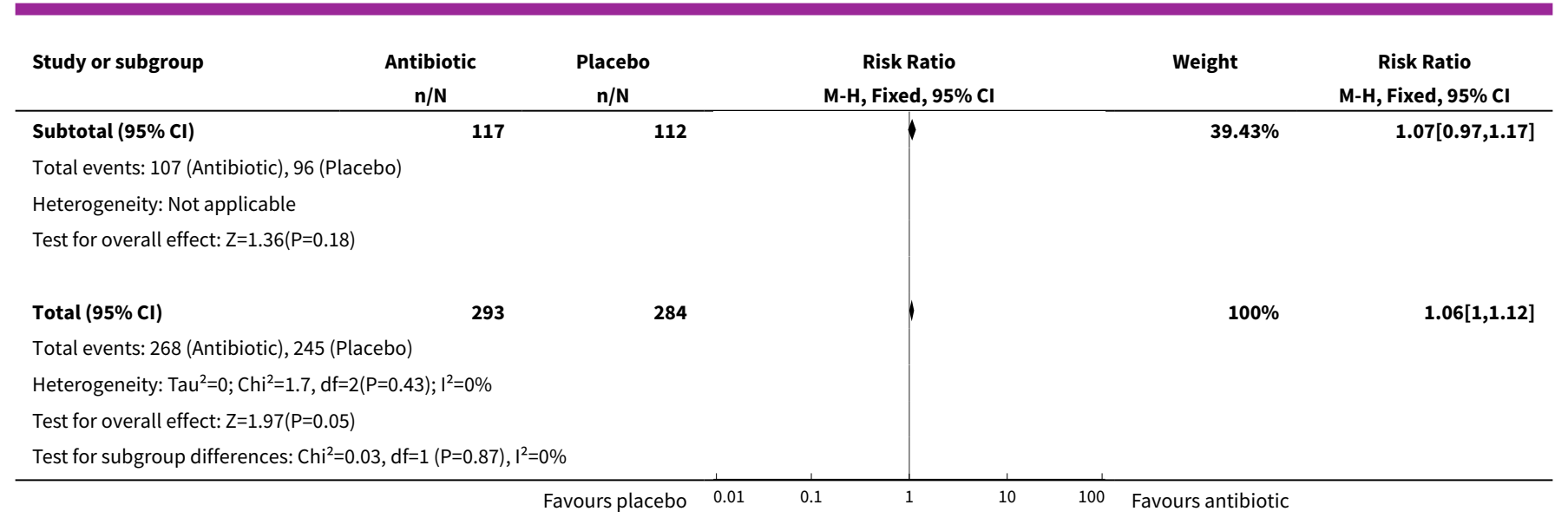

Analysis 5.6. Comparison 5 Any antibiotic treatment versus placebo (attrition bias), Outcome 6 Symptomatic improvement between the first and fourth week.

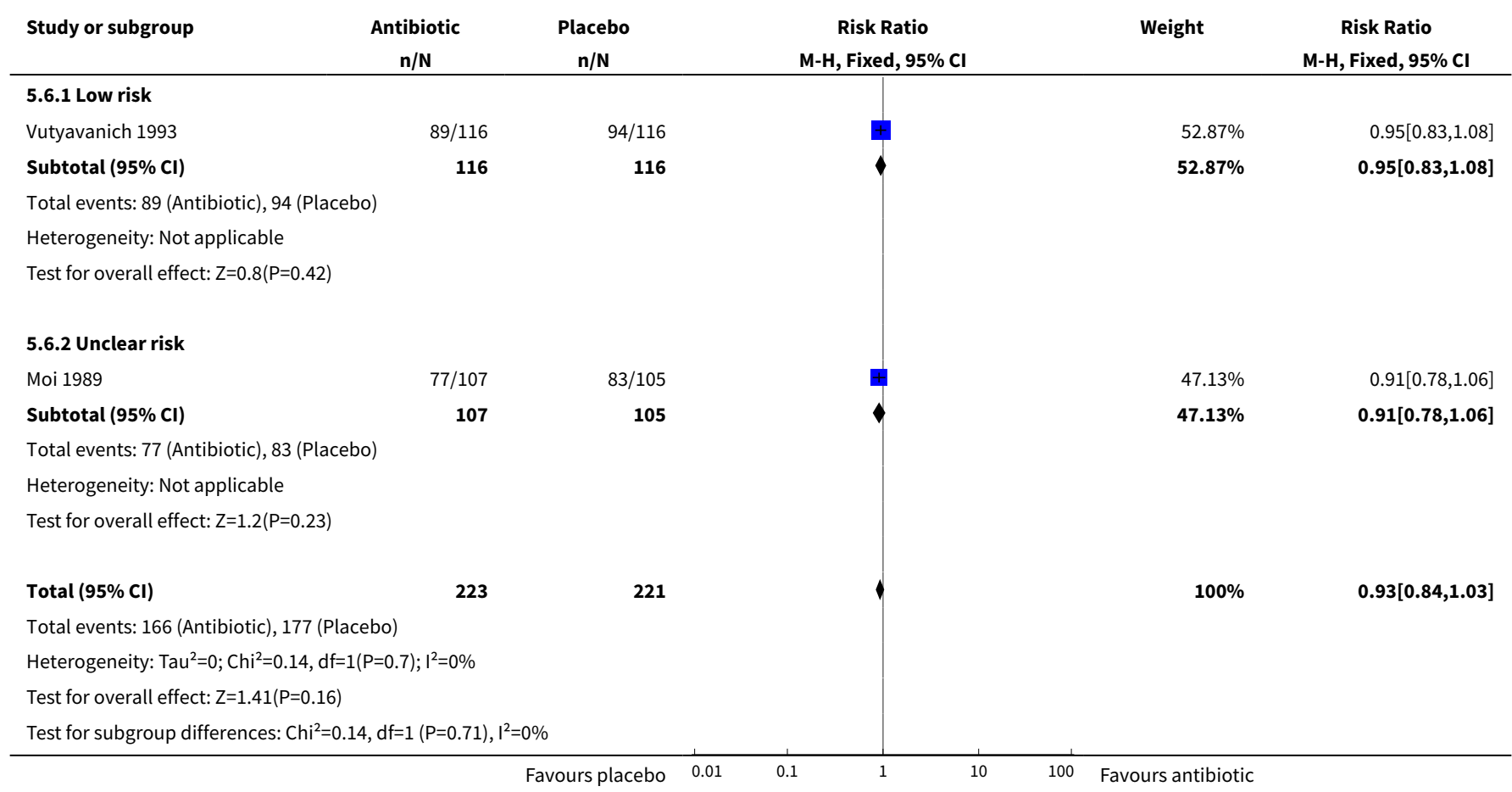

Analysis 5.7. Comparison 5 Any antibiotic treatment versus placebo (attrition bias), Outcome 7 Symptomatic improvement after the fourth week.

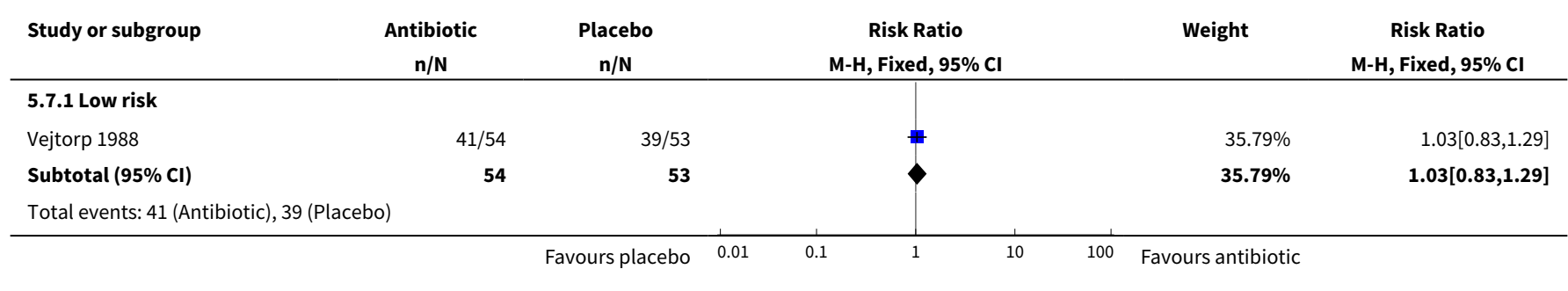




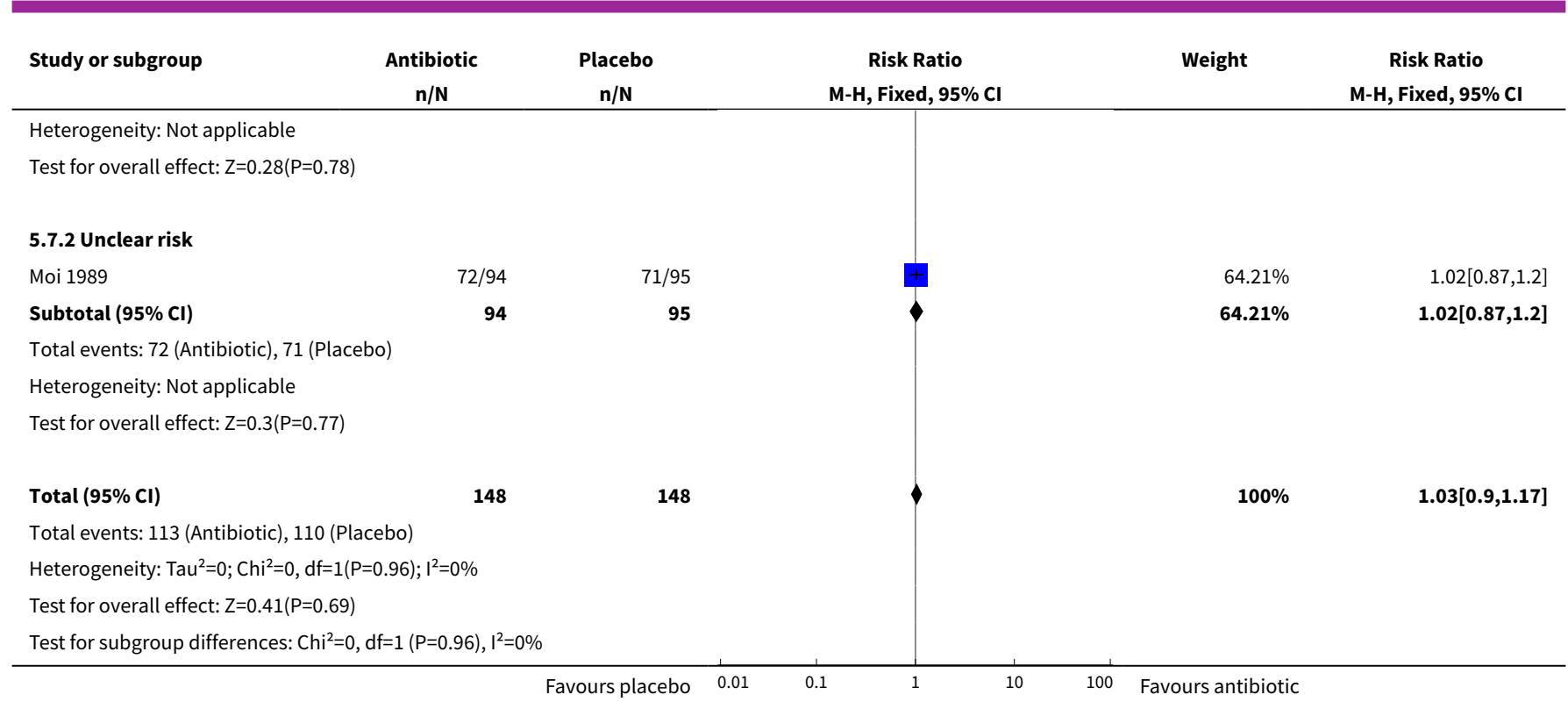

\section{Analysis 5.8. Comparison 5 Any antibiotic treatment versus placebo (attrition bias), Outcome 8 Minor adverse events during therapy in sexual partner.}

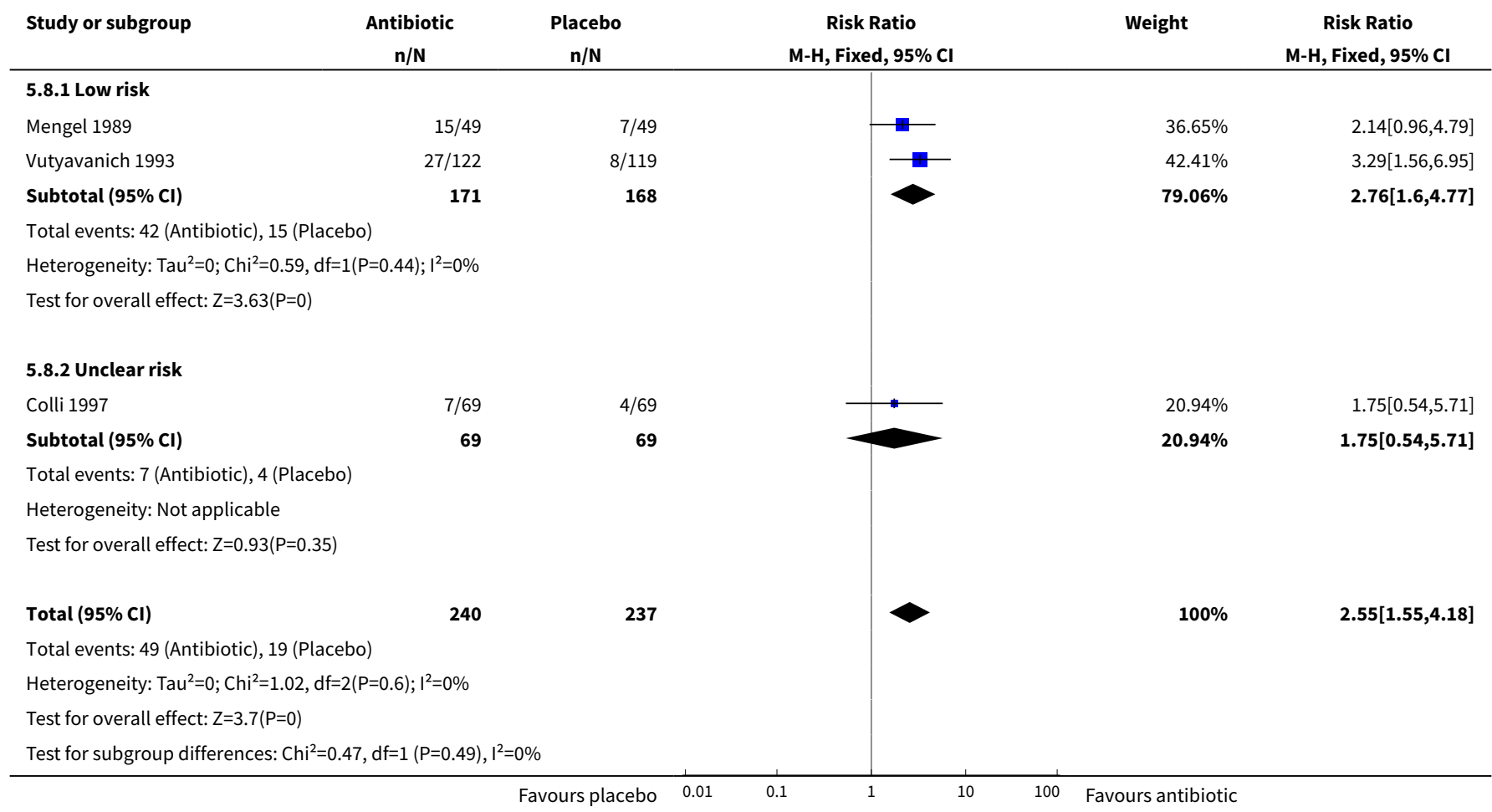




\section{A P P E N D I CES}

\section{Appendix 1. MEDLINE and CENTRAL search strategy}

1 exp Vaginosis, Bacterial/

2 (vagin $\$$ adj5 bacteri\$).tw.

31 or 2

4 exp Bacterial Infections/

5 (bacteri\$ adj5 infection\$).tw.

64 or 5

7 exp Vaginitis/

8 vaginiti*.tw.

9 vaginosis.tw.

10 colpitis.tw.

11 kolpitis.tw.

12 or/7-11

136 and 12

143 or 13

15 (antibacterial adj5 therapy).tw.

16 (antimicrobial adj5 treatment).tw

17 (antimicrobial adj5 therapy).tw.

18 (antibacterial adj5 treatment).tw

1915 or 16 or 17 or 18

20 exp Anti-Infective Agents/

21 (anti-infective adj5 agent\$).tw.

22 (antiinfective adj5 agent\$).tw.

23 microbicide\$.tw.

24 (anti-microbial adj5 agent\$).tw.

25 (antimicrobial adj5 agent\$).tw.

26 exp Anti-Bacterial Agents/

27 antibiotic $\$ . t w$.

28 (anti-bacterial adj5 agent\$).tw.

29 (antibacterial adj5 agent\$).tw.

30 bacteriocid\$.tw.

31 or/20-30

32 exp Therapeutics/

33 therap\$.tw.

34 treatment $\$ . t w$.

35 or/32-34

3631 and 35

3719 or 36

38 exp Sexual Partners/

39 (sexual adj5 partner\$).tw.

40 (multiple adj5 partners).tw.

4138 or 39 or 40

42 randomized controlled trial.pt.

43 controlled clinical trial.pt.

44 randomized.ab.

45 placebo.ab.

46 clinical trials as topic.sh.

47 randomly.ab.

48 trial.ti.

49 OR/42-48

50 exp animals/ not humans.sh.

5159 not 50

5237 and 41 and 51

Note: The CENTRAL strategy does not include items 42 to 51

\section{Appendix 2. Embase search strategy}

1 'vaginosis, bacterial'/exp

2 (vagin ${ }^{\star}$ NEAR/5 bacteri $\left.^{\star}\right): a b, t i$

Antibiotic treatment for the sexual partners of women with bacterial vaginosis (Review) 
31 or 2

4 'bacterial infections'/exp

5 (bacteri* NEAR/5 infection*):ab,ti

64 or 5

7 'vaginitis'/exp

8 vaginiti* $^{*}$ ab,ti

9 vaginosis ${ }^{\star}: a b, t i$

10 colpitis*:ab,ti

11 kolpitis* $^{\star}$ ab,ti 56

12 or/7-11

136 and 12

143 or 13

15 (antibacterial NEAR/5 therapy):ab,ti

16 (antibacterial NEAR/5 treatment):ab,ti

17 (antimicrobial NEAR/5 therapy):ab,ti

18 (antimicrobial NEAR/5 treatment):ab,ti

19 or/15-18

20 'anti-infective agents'/exp

21 ('anti infective' NEAR/5 agent*):ab,ti

22 (antiinfective NEAR/5 agent ${ }^{\star}$ ):ab,ti

23 microbicide*:ab,ti

24 ('anti microbial' NEAR/5 agent ${ }^{\star}$ ):ab,ti

25 (antimicrobial NEAR/5 agent ${ }^{\star}$ ):ab,ti

26 'anti-bacterial agents'/exp

27 antibiotic $^{*}: a b, t i$

28 ('anti bacterial' NEAR/5 agent*):ab,ti

29 (antibacterial NEAR/5 agent ${ }^{\star}$ ):ab,ti

30 bacteriocid $^{*}: \mathrm{ab}, \mathrm{ti}$

31 or $/ 20-30$

32 'therapeutics'/exp

33 therap*:ab,ti

34 treatment $^{\star}: a b$, ti

35 or/32-34

3631 and 35

3719 OR 36

38 (sexual NEAR/5 partner ${ }^{\star}$ ):ab,ti

39 (multiple NEAR/5 partners):ab,ti

4038 or 39

41 'randomised controlled trial'/exp

42 'single blind procedure'/exp

43 'double blind procedure'/exp

44 'crossover procedure'/exp

45 or/41-44

46 random $^{\star}: a b, t i$

47 placebo*:ab,ti

48 allocat $^{\star}: a b, t i$

49 crossover $^{*}: a b, t i$

50 'cross over':ab,ti

51 trial:ti

52 (doubl $^{\star}$ NEXT/1 blind ${ }^{\star}$ ):ab,ti

53 or/46-53

5445 or 53

55 'animal'/de

56 'animal experiment'/de

57 'nonhuman'/de

58 or/55-57

59 'human'/de

6058 and 59

6158 not 60

6254 not 61

6337 and 40 and 62 


\section{Appendix 3. LILACS search strategy}

(mh:(vaginosis, bacterial)) OR (ti:(vaginosis)) OR (ab:(vaginosis)) AND db:("LILACS")

RCTs filter:

((PT:"ensayo clinico controlado aleatorio" OR PT:"ensayo clinico controlado" OR PT:"estudio multicéntrico" OR MH:"ensayos clinicos controlados aleatorios como asunto" OR MH:"ensayos clinicos controlados como asunto" OR MH:"estudios multicéntricos como asunto" OR MH:"distribución aleatoria" OR MH:"método doble ciego" OR MH:"metodo simple-ciego") OR ((ensaio\$ OR ensayo\$ OR trial\$) AND (azar OR acaso OR placebo OR control\$ OR aleat\$ OR random\$ OR enmascarado\$ OR simpleciego OR ((simple\$ OR single OR duplo\$ OR doble \$ OR double\$) AND (cego OR ciego OR blind OR mask))) AND clinic\$)) AND NOT (MH:animales OR MH:conejos OR MH:ratones OR MH:ratas OR MH:primates OR MH:perros OR MH:gatos OR MH:porcinos OR PT:"in vitro")

\section{Appendix 4. Web of Science search strategy}

(TS=("vaginosis")) AND TS=(partner*) AND Tl=(trial)

\section{Appendix 5. ClinicalTrials.gov search strategy}

vaginosis AND partner

Appendix 6. World Health Organization (WHO) International Clinical Trials Registry Platform (ICTRP) search strategy vaginosis AND partner

\section{Appendix 7. Cochrane Sexually Transmitted Infection Group's Specialized Register search strategy}

1 (vaginosis:AB) AND (INREGISTER)

2 (vaginosis:TI) AND (INREGISTER)

3 (partner:AB) AND (INREGISTER)

4 (partner:TI) AND (INREGISTER)

5 (1 OR 2) AND ( 3 OR 4)

\section{CONTRIBUTIONS OF AUTHORS}

JA-G and CFG-A screened the titles of articles identified by the literature search, assessed the quality of the evidence in the included trials, extracted data, performed data analyses, wrote the first draft of the review and made subsequent amendments. DAV-C and EMS-B participated in screening the title of articles, assessed trial quality, extracted data and wrote the first draft of the review. MYM-V assessed trial quality, performed data analyses, commented on and revised the systematic review draft.

\section{DECLARATIONS OF INTEREST}

Jairo Amaya-Guio has no known conflicts of interest, Mercy Yolima Martinez-Velasquez has no known conflicts of interest, David Andres Viveros-Carreño has no known conflicts of interest, Eloisa Mercedes Sierra-Barrios has no known conflicts of interest, Carlos F Grillo-Ardila has no known conflicts of interest. None of review authors are or have been involved with the included studies in this review.

\section{SOURCES OF SUPPORT}

\section{Internal sources}

- No sources of support supplied

\section{External sources}

- National University of Colombia, Colombia.

\section{INDEX TERMS}

\section{Medical Subject Headings (MeSH)}

*Secondary Prevention; *Sexual Partners; Anti-Bacterial Agents [adverse effects] ["therapeutic use]; Clindamycin [therapeutic use]; Indazoles [therapeutic use]; Lincosamides [therapeutic use]; Metronidazole [therapeutic use]; Randomized Controlled Trials as Topic; Recurrence; Time Factors; Tinidazole [therapeutic use]; Vaginosis, Bacterial [ ${ }^{\star}$ prevention \& control]

\section{MeSH check words}

Adolescent; Adult; Female; Humans; Male; Middle Aged 